\author{
UNIVERSIDADE DE SÃO PAULO \\ ESCOLA DE ENGENHARIA DE SÃO CARLOS \\ DEPARTAMENTO DE HIDRÁULICA E SANEAMENTO
}

CRISTIAN PABLO YOULTON MILLON

QUANTIFICAÇÃO EXPERIMENTAL DA

ALTERAÇÃO NO BALANÇO HÍDRICO E EROSÃO EM UM NEOSSOLO QUARTZARÊNICO DEVIDO À SUBSTITUIÇÃO DE PASTAGEM POR CANA-DEAÇÚCAR

São Carlos

2013 



\section{QUANTIFICAÇÃO EXPERIMENTAL DA ALTERAÇÃO NO BALANÇO HÍDRICO E EROSÃO EM UM NEOSSOLO QUARTZARÊNICO DEVIDO À SUBSTITUIÇÃO DE PASTAGEM POR CANA-DE- AÇÚCAR}

Tese apresentada ao Programa de PósGraduação em Engenharia Hidráulica e Saneamento da Escola de Engenharia de São Carlos (EESC), Universidade de São Paulo (USP), para obtenção do título de Doutor em Ciências: Engenharia Hidráulica e Saneamento.

Orientador: Prof. Dr. Edson Cezar Wendland

VERSÃO CORRIGIDA

São Carlos

2013 


\section{AUTORIZO A REPRODUÇÃO TOTAL OU PARCIAL DESTE TRABALHO, POR QUALQUER MEIO CONVENCIONAL OU ELETRÔNICO, PARA FINS DE ESTUDO E PESQUISA, DESDE QUE CITADA A FONTE.}

Youlton Millon, Cristian Pablo
Y67q Quantificação experimental da alteração no balanço hídrico e erosão em um Neossolo Quartzarênico devido à substituição de pastagem por cana-de-açúcar / Cristian Pablo Youlton Millon; orientador Edson Cezar Wendland. São Carlos, 2013.

Tese (Doutorado) - Programa de Pós-Graduação e Área de Concentração em Hidráulica e Saneamento - - Escola de Engenharia de São Carlos da Universidade de São Paulo, 2013.

1. Sedimentos. 2. Precipitação. 3. Escoamento. 4. Cobertura do solo. I. Título. 
FOLHA DE JULGAMENTO

Candidato: Engenheiro CRISTIAN PABLO YOULTON MILLON.

Título da tese: "Quantificação experimental do balanço hídrico e erosão de sólidos devido à substituição de pastagem por cana-de-açúcar".

Data da defesa: 24/07/2013

\section{Comissão Julgadora:}

Prof. Titular Edson Cezar Wendland (Orientador)

(Escola de Engenharia de São Carlos/EESC)

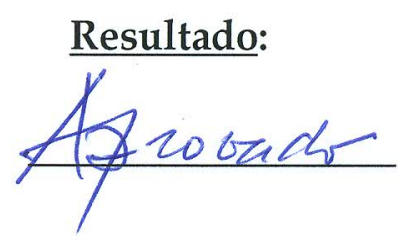

Prof. Associado Rodrigo de Melo Porto

(Escola de Engenharia de São Carlos/EESC)

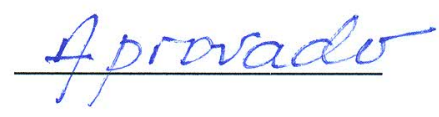

Dr. Silvio Crestana

(EMBRAPA)

Prof. Dr. Cristiano Poleto

(Universidade Tecnológica Federal do Paraná/UTFPR)

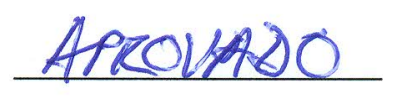

Prof. Dr. Ademir Paceli Barbassa

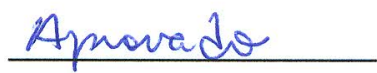

(Universidade Federal de São Carlos/UFSCar)

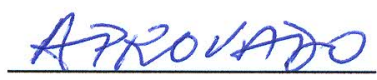

Coordenador do Programa de Pós-Graduação em Engenharia Hidráulica e Saneamento:

Profa. Assoc. Maria Bernadete A. Varesche Silva

Presidente da Comissão de Pós-Graduação:

Prof. Titular Denis Vinicius Coury 



\section{AGRADECIMENTOS}

Quero agradecer a todas as pessoas que me acompanharam, influenciaram, apoiaram e participaram desta conquista pelo doutorado e também em todas as minhas experiências em terras brasileiras.

Agradeço a minha família, por ter me dado oportunidades, auxílio, incentivo e condições para desenvolver minha curiosidade e capacidade de nunca parar de aprender.

Agradeço as pessoas que me incentivaram a vir estudar nesse pais, nessa cidade e nessa faculdade. Ao meu orientador Edson Wendland, que não só abriu as portas da USP, mas também foi um amigo e abriu as portas da sua casa e sua família. A Daniele Vanzo e seus pais, Helena e Wamberto, que me acolheram e apoiaram para me instalar em terras aleias, se tornando minha família em São Carlos.

Agradeço a amizade e companheirismo dos colegas do Laboratório de Hidráulica Computacional, àqueles que me receberam, e àqueles que apareceram depois: Camilo Cabrera, Rafael Chaves, Ivan Marin, Marjolly Shinzato, Aline Ribeiro, Tais Shiratsubaki, Paulo Tarso, Murilo Lucas, Antonio Meira, Davi Diniz, Ana Bragion, Frederico Martins e Thiago Matos. Muito obrigado a todos pela amizade e apoio no trabalho, pelos bons e frequentes churrascos na casa do Edson e dos encontros no bar do Toco, nos tornando um grupo unido, sem diferenças entre orientador e orientandos.

Agradeço as pessoas da USP que com seu dedicado trabalho apoiaram a realização da tese: Rose (recepcionista), Pavi, Sá e Priscilla (secretarias) Flávia e Fernanda (Contabilidade), André (Computação), e Roberto Bergamo (técnico). Obrigado a todos pela disposição e ajuda, muito silente, mas muito importante para o desenvolvimento do projeto. Sempre atenciosos e com um sorriso na rosto.

Agradeço as instituições que apoiaram, auxiliaram ou fizeram parte da pesquisa: Fapesp pelo auxílio ao projeto de pesquisa, Capes e CNPq pela concessão de bolsa, Instituto Arruda Botelho e Fazenda Conquista por sediar o experimento e pela ajuda em sua construção.

Finalmente agradeço ao Brasil por ter me acolhido durante 4 anos, pelas experiências vividas, os lugares e pessoas conhecidas, e por ter me dado a oportunidade de melhorar professional e pessoalmente. Hoje, me considero um pouco brasileiro também. 



\section{RESUMO}

YOULTON, C. Quantificação experimental da alteração no balanço hídrico e erosão em um Neossolo Quartzarênico devido à substituição de pastagem por cana-de-açúcar. 2013. 62 f. Tese (Doutorado) - Escola de Engenharia de São Carlos, Departamento de Hidráulica e Saneamento, Universidade de São Paulo, São Carlos, 2013.

A cana-de-açúcar tornou-se a cultura com maior expansão nos últimos anos no estado de São Paulo, tendência que deve continuar, considerando sua importância como matéria prima para a produção de açúcar e etanol. Essa expansão acontece principalmente sobre áreas que eram ocupadas por pastagens. Pelas atividades necessárias para o estabelecimento da cultura de cana-de-açúcar, é esperado um aumento da erosão de solos e uma alteração no balanço hídrico. Com esses antecedentes, objetivou-se quantificar experimentalmente o impacto na erosão dos solos e a modificação do balanço hídrico no primeiro metro de solo, causado pela substituição de pastagem por cana-de-açúcar. Foram construídas parcelas de escoamento $\left(20 \times 5 \mathrm{~m}^{2}\right)$ sob pastagem e sob plantio novo de cana-de-açúcar (três repetições cada) em uma fazenda com solo do tipo Neossolo Quartzarênico no município de Itirapina-SP. Foi instalada uma estação meteorológica para medir a precipitação e a umidade do solo a 30, 60 e $90 \mathrm{~cm}$ de profundidade, e para coletar os parâmetros necessários para calcular a evapotranspiração pelo método de Penman-Monteith. Calhas foram instaladas ao nível do solo para quantificar a interceptação do dossel de cana-de-açúcar. O balanço hídrico para ambos os cultivos foi determinado em escala diária. Após cada evento de precipitação, foi quantificada a perda de solos e o escoamento superficial Durante o primeiro ano, a perda de solo sob pastagem foi de 0,26 Mg.ha-1.ano-1, (adicionalmente, 0,32 Mg.ha-1 foram coletados devido à perturbação do solo para implantação do experimento), enquanto cana-de-açúcar produziu 2,58 Mg.ha-1.ano-1. No segundo período chuvoso, a perda de solo sob pastagem diminui para 0,04 Mg.ha-1, e sob cana-de-açúcar registrou 0,47 Mg.ha-1. Estes resultados indicam que a substituição de pastagem por cana-de-açúcar aumentou a produção de sedimentos durante o primeiro ano em 2,32 Mg.ha-1; no segundo período, com o uso da cobertura de palha no solo sob cana-de-açúcar, o aumento foi de 0,43 Mg.ha-1 ${ }^{-1}$ Depois de quatro meses de crescimento, o dossel da cana-de-açúcar intercepta $40 \%$ da precipitação. O escoamento superficial no primeiro ano foi de $56,1 \mathrm{~mm}$, e diminuiu para $11,8 \mathrm{~mm}$ no segundo período por efeito da palha na superfície do solo. Nos mesmos períodos, o escoamento superficial na pastagem foi de 40,5 $\mathrm{mm}$ e $30,4 \mathrm{~mm}$, respectivamente. Apesar da menor infiltração sob cana-de-açúcar, o solo apresenta maior umidade devido ao gradeamento que aumenta a porosidade, e portanto, a capacidade de armazenamento de água no solo. A percolação sob cana-de açúcar é menor que sob pastagem devido à maior evapotranspiração da cultura.

Palavras-chave: Sedimentos. Precipitação. Escoamento. Cobertura do solo. 


\section{ABSTRACT}

YOULTON, C. EXPERIMENTAL DETERMINATION OF WATER BALANCE AND SOIL EROSION CHANGES DUE TO PASTURE SUBSTITUTION BY SUGARCANE. 2013. 62 p. Thesis (PhD) - Escola de Engenharia de São Carlos, Departamento de Hidráulica e Saneamento, Universidade de São Paulo, São Carlos, 2013.

Sugarcane became the culture with the highest expansion in recent years in the state of São Paulo. This trend will continue considering its importance as raw material for the production of sugar and ethanol. The expansion occurs primarily on areas that are currently occupied by pastures, causing impacts on soil and water. Due to the necessary activities for the establishment of the sugarcane culture, a soil erosion increase and a water balance change are expected. With this background, the objective of this work was to experimentally quantify the change in soil erosion and modification of water balance in the first meter of soil caused by the substitution of pasture by sugarcane. Runoff plots were constructed $\left(20 \times 5 \mathrm{~m}^{2}\right)$ under pasture and new sugarcane planting (three replicates each) on a farm with Quartzarenic Neosol (Typic Quartzipsamments) soil in the municipality of Itirapina-SP. A weather station to measure rainfall and soil moisture at 30,60 and $90 \mathrm{~cm}$ depth, and to collect the necessary parameters to calculate the evapotranspiration by Penman-Monteith method was installed. Gutters were installed at ground level to quantify the interception of the sugarcane canopy. After every precipitation event the soil loss and the drainage were quantified, and the daily water balance was determined for both soil uses. During the first year, the pasture had a soil loss of $0.26 \mathrm{Mg} \mathrm{ha}^{-1} \cdot \mathrm{yr}^{-1}$ (additional $0.32 \mathrm{Mg} \mathrm{ha}^{-1} \cdot \mathrm{yr}^{-1}$ were collected due to the disturbance of the soil during experiment installation), while sugarcane produced $2.58 \mathrm{Mg} \mathrm{ha}^{-1} \cdot \mathrm{yr}^{-1}$. In

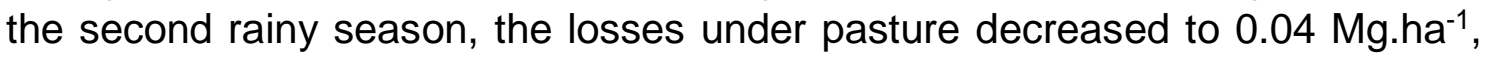
and sugarcane recorded $0.47 \mathrm{Mg} \cdot \mathrm{ha}^{-1}$. These results indicate that the replacement of pasture by sugarcane increased the sediment production during

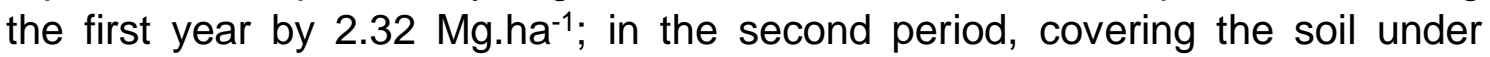
sugarcane with straw, the difference decreased to $0.43 \mathrm{Mg}^{-h^{-1}}{ }^{-1}$ After four months of growth, the sugarcane canopy intercepts $40 \%$ of the precipitation. The runoff in the first year was $56.1 \mathrm{~mm}$, decreasing to $11.8 \mathrm{~mm}$ in the second period, due to the presence of straw on the soil surface. In the same periods, runoff under pasture was $40.5 \mathrm{~mm}$ and $30.4 \mathrm{~mm}$, respectively. Although there is less infiltration under sugar cane, the soil presents higher moisture due to the porosity increase by grating. The percolation under sugarcane is lower than in pasture due to a higher crop evapotranspiration.

Keywords: Sediments. Precipitation. Runoff. Soil cover. 


\section{LISTA DE FIGURAS}

Figura 1 - Localização da área experimental no estado de São Paulo. 15

Figura 2 - Estação meteorológica instalada na área de estudo, ao lado das parcelas com pastagem. 16

Figura 3 - Esquema da distribuição das parcelas de escoamento e sensores segundo tratamento. 18

Figura 4 - Parcela sob cana-de-açúcar e parcela sob pastagem. 19

Figura 5 - Conjunto de caixas d'água e divisores para armazenamento do escoamento e sedimentos. 19

Figura 6 - Coleta dos sedimentos grossos do coletor, usando espátula, escova e sacolas plásticas rotuladas. 20

Figura 7 - Coleta de amostras de escoamento e sedimentos finos em garrafa plástica das caixas d'água, após homogeneização do escoamento ................ 21

Figura 8 - Calha d'água para medição da interceptação ................................ 22

Figura 9 - Instalação do sensor de umidade marca Sentek, modelo EnviroScan, no tubo de acesso na parcela de pastagem.

Figura 10 - Registro dos eventos de precipitação $(\mathrm{mm})$ e sua intensidade máxima em 10 minutos $\left(\mathrm{mm} .10 \mathrm{~min}^{-1}\right)$. 27

Figura 11 - Escoamento superficial, interceptação, e precipitação total por evento e cultura. 29

Figura 12 - Escoamento, interceptação e precipitação total por mês e cultura. 30 Figura 13 - Erosão por evento e cultura. 33

Figura 15 - Escoamento superficial retido nos sulcos de cana-de-açúcar num evento de chuva. 34

Figura 14 - Escoamento, interceptação, precipitação total e erosão por mês e cultura 
Figura 16 - Superficie do solo nos entre-sulcos sob cana-de-açúcar, apresentando um selamento superficial e pequenas ravinas ao longo das parcelas. 35

Figura 17 - Parcelas de cana-soca um mês apôs a colheita, com os entresulcos gradeados e cobertura de palha a cada três entre-sulcos. 36

Figura 18 - Variação da interceptação ao longo do tempo, expressa em porcentagem da precipitação de cada evento. 38

Figura 19 - Umidade do solo em pastagem e cana-de-açúcar expresso em porcentagem, às profundidades de 30,60 e $90 \mathrm{~cm}$. 41

Figura 20 - Lâmina de umidade armazenada até $1 \mathrm{~m}$ de profundidade, para solo sob pastagem e cana-de-açúcar.

Figura 21 - Variação diária de umidade no primeiro metro do solo em pastagem e cana-de-açúcar, expressos em mm. 44

Figura 22 - Evapotranspiração potencial de referência e evapotranspiração em pastagem e cana-de-açúcar, calculados segundo o método Penman-Monteith.

Figura 23 - Evapotranspiração ajustada em função da umidade do solo, medida por cultura. 47

Figura 24 - Percolação através do primeiro metro do solo sob pastagem e cana-de-açúcar . 50

Figura 25 - Balanço hídrico acumulado para as culturas de pastagem e canade-açúcar 52

\section{LISTA DE TABELAS}

Tabela 1 - Valores de Kc para cana-planta

Tabela 2 - Valores de Kc para cana-soca 


\section{SUMÁRIO}

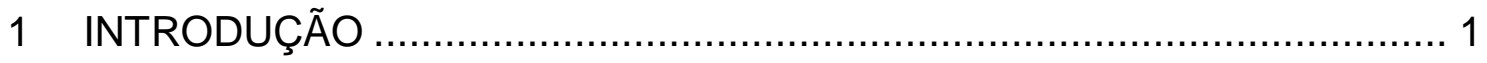

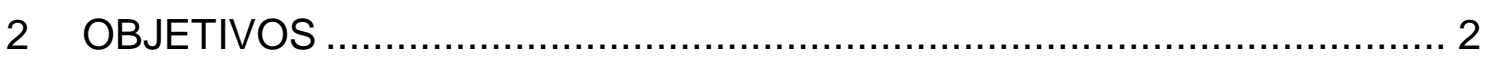

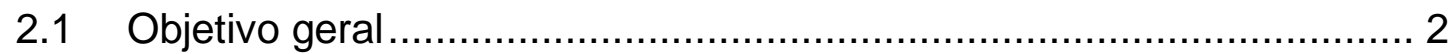

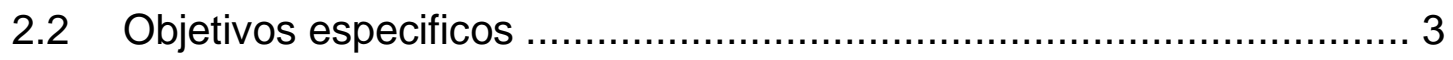

3 REVISÃO BIBLIOGRÁFICA ……..................................................... 3

3.1 Definição e antecedentes da erosão ............................................. 3

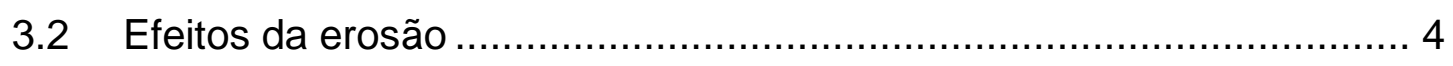

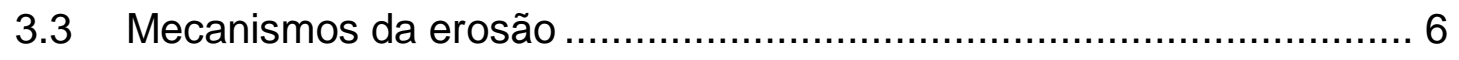

3.4 Medição da erosão em campo ............................................... 9

3.5 Erosão de solos nas culturas de cana-de-açúcar e pastagem.............11

3.6 Balanço hídrico nas culturas de cana-de-açúcar e pastagem............ 13

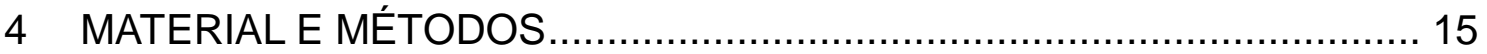

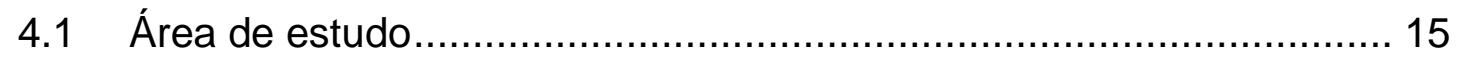

4.2 Registro das precipitações ................................................. 16

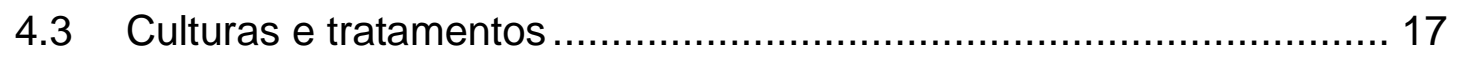

4.4 Monitoramento de escoamento e erosão de solos .......................... 18

4.5 Balanço hídrico ................................................................. 21

4.6 Analise estatística ......................................................... 25

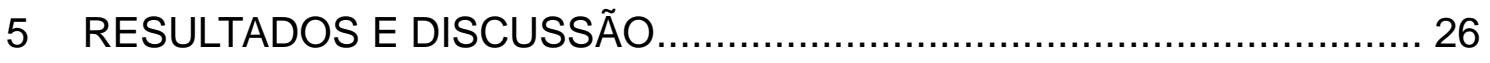

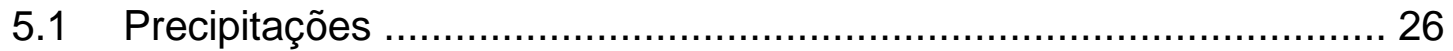

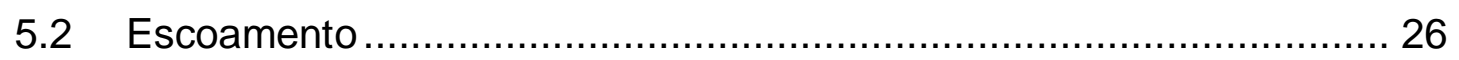

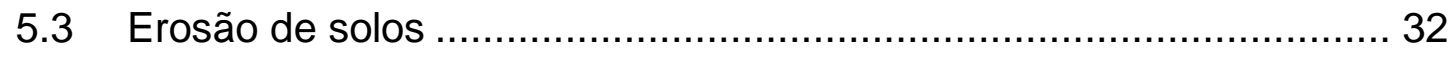

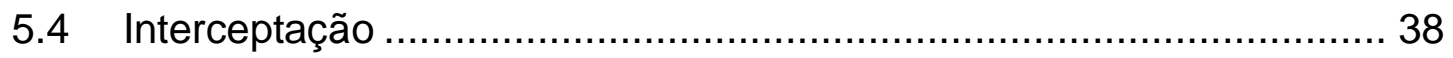




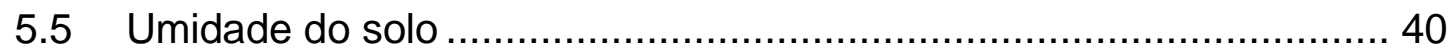

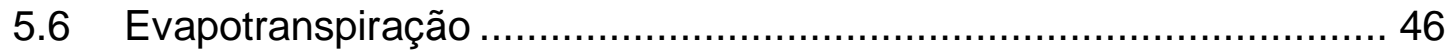

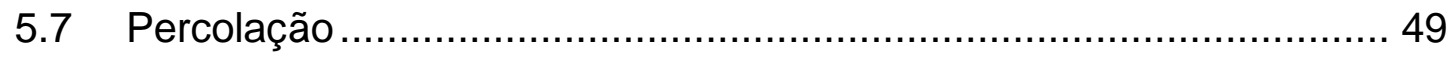

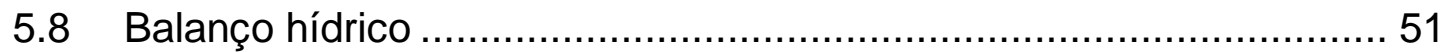

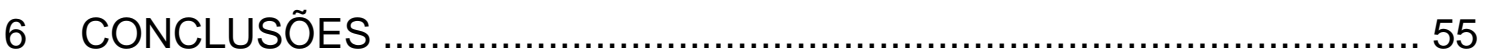

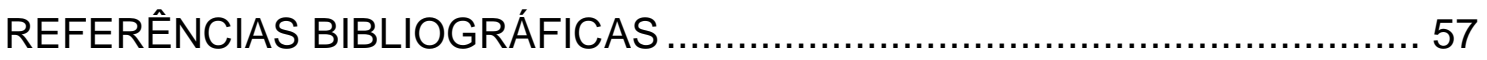

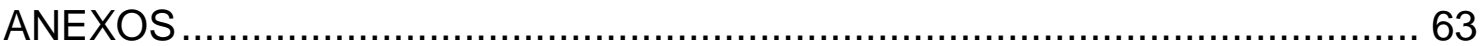




\section{INTRODUÇÃO}

Durante o ano de 2011, foram produzidas no mundo 1.794 milhões de toneladas de cana-de-açúcar (Saccharum officinarum) em 25.436.924 hectares de área plantada. No mesmo ano, o Brasil produziu mais de 734 milhões de toneladas de cana-de-açúcar, equivalente a $41 \%$ da produção mundial, destinando para tanto 9,6 milhões de hectares. Com estes valores, o Brasil ocupa o primeiro lugar na produção mundial de cana-de-açúcar, seguido por Índia e China (FAO, 2013). Segundo dados da União da Indústria de Cana-deaçúcar (UNICA, 2013), o Estado de São Paulo teve 5,2 milhões de hectares sob cultura de cana-de-açúcar durante o ano de 2011, representando 54\% da superfície no Brasil e $21 \%$ da superfície destinada à cultura no mundo.

Segundo dados do Instituto de Economia Agrícola (IEA) do Governo do Estado de São Paulo, entre os anos de 2007 e 2011, a superfície cultivada com cana-de-açúcar para uso industrial no Estado de São Paulo cresceu de 4.800.070 para 5.841 .580 hectares (equivalente a $21 \%$ da superfície total do Estado), ao mesmo tempo em que a área destinada à pastagem diminuiu de 9.185.658 para 7.435.777 hectares (IEA, 2008; 2012). A mencionada substituição cresceu rapidamente durante a última década (RUDORFF et al., 2010; WALTER et al., 2011; ADAMI et al., 2012) devido principalmente ao uso de cana-de-açúcar como matéria prima para a produção de açúcar e etanol como biocombustível, tanto para consumo doméstico quanto para exportação (WALTER et al., 2011).

Diferentemente da pastagem, que apresenta uma cobertura vegetal permanente, a cultura de cana-de-açúcar pode produzir efeitos ambientais negativos, como a erosão pela exposição de solos descobertos e lavrados profundamente no estabelecimento e renovação da cultura a cada 5 ou 6 anos e entre a coleta anual e o novo crescimento (MARTINELLI; FILOSO, 2008). O solo é compactado pela passagem das máquinas usadas na colheita e renovação da cultura, diminuindo a infiltração das chuvas e aumentando o escoamento superficial e a erosão (GARBIATE et al., 2011; AZADI et al., 2012). 
As partículas de solo erodidas provocam turbidez e assoreamento dos corpos de água, além de transportarem poluentes agroquímicos (LAL, 2001).

Pastagem e cana-de-açúcar diferem no volume aéreo (responsável pela evapotranspiração e interceptação da precipitação), na profundidade das raízes (extraindo água de diferentes níveis do solo) e nos requerimentos hídricos. Deste modo, a substituição das culturas também teria um efeito no balanço hídrico do solo.

No Estado de São Paulo, pesquisas têm sido desenvolvidas a fim de determinar as perdas de solo nessas culturas, porém sem avaliar diretamente a substituição sob as mesmas condições experimentais. Alguns destes estudos baseiam-se na simulação de chuvas ou ainda na aplicação de modelos internacionais (MINOTI, 2006; WEILL; SPAROVEK, 2008; AMORIM et al., 2010; GALHARTE, 2011; LELIS et al., 2012) sem validação e calibração local dos resultados de erosão a partir de medições diretas de campo. O mesmo acontece com estudos que avaliam o balanço hídrico, os quais são parciais e não consideram todos os componentes envolvidos nele.

Tendo em vista esses antecedentes, quantificou-se a alteração na erosão dos solos e a modificação do balanço hídrico causados pela substituição de pastagem por cana-de-açúcar numa mesma área experimental, no primeiro metro de solo.

\section{OBJETIVOS}

\subsection{Objetivo geral}

Avaliar experimentalmente o impacto sobre a perda de solos e o balanço hídrico devido à substituição de pastagem (Brachiaria decumbens) por cana-de-açúcar (Saccharum officinarum). 


\subsection{Objetivos especificos}

Determinar, experimentalmente, a erosão do solo Neossolo Quartzarênico e o escoamento em áreas vegetadas por cana-de-açúcar e pastagem sob pastejo rotacionado, numa vertente com $9 \%$ de declividade na Fazenda São José, município de Itirapina-SP.

Quantificar as componentes do balanço hídrico (precipitação, interceptação, escoamento, umidade do solo até o primeiro metro de profundidade, evapotranspiração e percolação) para as ditas culturas sob as condições anteriormente descritas.

\section{REVISÃO BIBLIOGRÁFICA}

\subsection{Definição e antecedentes da erosão}

A erosão (do Latim, erosǐo, - ōnis, roedura) do solo é a remoção do material superficial por ação do vento e da água (KIRKBY; MORGAN, 1980), abrangendo o processo de sedimentação, inclui uma fase de desprendimento de partículas individuais do solo e sua suspensão, uma segunda fase de transporte de partículas por agentes hídricos e eólicos, e uma terceira fase quando a energia destes agentes não é suficiente para transportar as partículas, provocando sua deposição (TOY; FOSTER; RENARD, 2002; MORGAN, 2009).

É possível distinguir dois tipos de erosão segundo sua origem i) Erosão geológica ou natural, e ii) erosão antrópica ou acelerada. A primeira é aquela que ocorre na natureza através de milhões de anos (tempo geológico) mediante processos de intemperização das rochas na superfície da terra, onde as taxas de erosão prevalecem sob as condições ambientais não perturbadas ou naturais. A quantidade de solo formado geralmente se encontra em equilíbrio com o solo removido por agentes erosivos (TOY; FOSTER; RENARD, 2002).

Pelo contrário, a erosão antrópica apresenta-se sob condições ambientais perturbadas, sendo as taxas de erosão incrementadas em várias ordens de 
magnitude. Normalmente é resultado da atividade humana ao remover a cobertura vegetal e expor o solo aos agentes erosivos.

Indícios de erosão antrópica têm sido encontrados no começo da agricultura mesopotâmica. A antiga Vila de Jarmo, no norte de Iraque, é considerada a primeira localidade a utilizar a agricultura 11.000 anos antes de Cristo. Esta vila estava localizada sobre um tablado de solo fértil, friável e facilmente arável. Pode-se destacar que a agricultura foi inicialmente praticada nos solos com pouca declividade nos fundos dos vales, onde a erosão potencial é baixa. Porém, com o aumento da população, aumentaram a demanda por alimentos, causando a expansão da agricultura e das zonas de pastoreio em direção das zonas mais altas do vale, que apresentam maior declividade e são, portanto, mais suscetíveis a erosão. A erosão destas vertentes causou a sedimentação sobre campos e aldeias localizados na parte baixa do vale, e eventualmente diminuiu a produtividade agrícola. Com o aumento da população, aumentou, também, a demanda por combustível, resultando no desmatamento das vertentes, provocando novamente altas taxas de erosão sobre vastas extensões. Este fator foi o que provavelmente contribuiu para a queda de algumas civilizações (TOY; FOSTER; RENARD, 2002).

\subsection{Efeitos da erosão}

Os efeitos da erosão se manifestam tanto no lugar onde se produzem (in situ) como fora dele (ex situ).

Os agentes erosivos removem in situ a camada superior do solo (horizonte A) e a matéria orgânica contida nele, deixando exposto horizontes profundos. Estes tem menor capacidade de infiltração, facilitando o escoamento superficial. A menor infiltração e volume de retenção d'água modifica o balanço hídrico no perfil do solo, restringindo a água disponível para as plantas. Finalmente, diminui a fertilidade do solo, já que os nutrientes estão armazenados e reciclados nos horizontes superiores do solo. A remoção destas camadas por erosão diminui a quantidade de nutrientes disponíveis para as plantas (PRADO; VEIGA, 1994; LAL, 2001; TOY; FOSTER; RENARD, 2002). 
Em um solo erodido aumentam os custos de produção de alimentos em relação ao solo não erodido, devido a necessidade de utilizar uma quantidade maior de insumos para compensar os efeitos da perda de solo e sua fertilidade. Ao diminuir a profundidade diminui também o volume de enraizamento disponível para a planta. Todo o anterior se traduz em um detrimento na produção agrícola e uma menor rentabilidade do cultivo (TOY; FOSTER; RENARD, 2002). Finalmente, limita as espécies que podem ser cultivadas e leva à desvalorização e o abandono da terra (MORGAN, 2009), com o consequente problema social de emigração rural às zonas urbanas.

Os problemas ex situ estão relacionados com o efeito dos sedimentos nas águas à jusante. O assoreamento de canais, reservatórios e obras de irrigação diminuem a capacidade de transporte, a vida útil e aumentam os custos de manutenção. O maior efeito negativo é o assoreamento de rios (tornando-os inavegáveis) e portos (necessitando de dragagem) (PERALTA, 1976). A erosão também produz danos sobre infraestrutura de estradas, soterrando e cortando caminhos e pontes.

Os sedimentos transportados na água de irrigação devem ser eliminados para não obstruir o sistema de irrigação pressurizado, requerendo filtros. Os sedimentos também conferem turbidez à água potável, aumentando a frequência de substituição dos filtros, encarecendo o tratamento de água (PERALTA, 1976). Os sedimentos também são um contaminante por sua própria composição e pelos elementos químicos que podem levar absorbidos aumentando os níveis de nitrogênio e fósforo nas massas d'água, favorecendo assim sua eutrofização (MORGAN, 2009).

A deposição soterra solos e cultivos localizados nas zonas mais baixas. Estas deposições acarretam problemas de drenagem que impedem o normal escoamento das aguas, aumentando o risco de enchentes. Os sedimentos em suspensão afetam o plâncton dos lagos e margem costeiro, com sua morte ou sua imigração, alterando a cadeia trófica.

Outro efeito in situ da erosão é a perda da paisagem, limitando o potencial turístico e cênico das zonas afetadas (PERALTA, 1976). Finalmente, a erosão é um processo que exacerba o problema de degradação do solo, chegando 
ainda a contribuir com o efeito estufa. A erosão remove e deixa disponível o carbono orgânico e inorgânico contido no solo aos processos microbiológicos e químicos liberando $\mathrm{CO}_{2}$ (um dois principais gases estufa) à atmosfera. O solo é o terceiro maior depósito de carbono, depois dos oceanos, e dos depósitos fósseis (LAL, 2001).

Os custos in situ da erosão são assumidos pelo agricultor, embora possam ser transferidos em parte à sociedade, em termos de perda de competividade e preços mais altos dos alimentos, à medida que se produzem perdas de rendimentos ou abandono das terras de cultivo. $\mathrm{O}$ agricultor não assume os custos ex situ da erosão, que recaem sobre as autoridades locais, entidades governamentais, companhias seguradoras e proprietários dos terrenos afetados pela sedimentação e enchentes, os quais assumem as despesas pelo conserto e manutenção da infraestrutura danificada (MORGAN, 2009).

\subsection{Mecanismos da erosão}

A erosão do solo é um processo de duas fases consistentes no desprendimento de partículas individuais do solo e seu transporte pelos agentes erosivos, como as correntes de d'água e o vento. Quando a energia destes agentes não é suficiente para transportar as partículas, se produz sua deposição (MORGAN, 2009).

Os processos de erosão hídrica estão relacionados com as rotas que segue a água no seu passo através da cobertura vegetal e seu movimento sobre a superfície do solo. Durante uma chuva, parte da agua caí diretamente sobre o solo, seja porque não têm vegetação, ou porque passa através dos espaços da coberta vegetal. Esta fração de chuva se denomina precipitação direta. Parte da chuva é interceptada pela coberta vegetal, desde onde volta para a atmosfera por evaporação ou chega ao solo caindo das folhas (componente denominado drenagem foliar) e desce pelos caules. A precipitação direta e a drenagem foliar são responsáveis pela erosão por respingo ou salpicamento. A chuva que chega ao solo infiltra, contribuindo para umidade do solo, ou, por percolação, recarrega os aquíferos. Quando o solo é incapaz de armazenar mais água, o excesso se desloca horizontalmente pelo interior do solo e em 
favor da declividade, como fluxo sub-superficial ou contribui para o escoamento superficial provocando erosão como fluxo laminar ou em ravinas e voçorocas (MORGAN, 2009). Este escoamento superficial é o principal causador de erosão hídrica.

A velocidade com que o água passa ao interior do solo se denomina velocidade de infiltração e exerce o controle mais importante sobre a geração de escoamento superficial. A água move-se ao interior do solo pela ação da gravidade e é retida pelas forças capilares formando uma camada delgada ao redor das partículas do solo. Durante a chuva, enchem-se de água os espaços entre as partículas do solo e as forças capilares diminuem, de forma que a velocidade de infiltração começa alta no início da chuva, e diminui até o valor apresentado pela máxima velocidade estabilizada à que a água pode passar através do solo.

A velocidade de infiltração depende das características do solo. Geralmente, os solos de textura grossa, como os arenosos e franco arenosos, têm velocidades de infiltração maiores que solos argilosos, devido ao tamanho dos espaços entre as partículas do solo (macro-poros). Estes podem deixar passar quantidades importantes d'agua, e por este motivo, as argilas com estrutura estável e alta porosidade podem apresentar velocidades de infiltração maiores do que se esperaria de sua textura. Geralmente, se a intensidade da chuva é igual ou menor que a capacidade de infiltração do solo, não se produz escoamento superficial. Se a intensidade é maior que a capacidade de infiltração, o excedente de chuva forma escoamento superficial (MORGAN, 2009).

A erosão do solo começa com o desprendimento das suas partículas pelo impacto das gotas de chuva, pela força do arrastre d'agua, ou pela dissolução de seus agentes aglomerantes mediante reações químicas (LAL, 2001). O solo também se desagrega pelos processos de intemperização mecânica (alternância de umedecimento e dessecação, congelamento e degelo, ação do gelo, ou pelo pisoteio de homens e gado, ou gradagem do solo (MORGAN, 2009). Como resultados do impacto das gotas de chuva sobre a superfície de um solo exposto, as partículas do mesmo podem ser lançadas pelo ar a vários centímetros de distância. 
Uma vez desagregadas as partículas do solo, o escoamento pode atuar superficialmente em camadas ou concentrado em córregos. No primeiro caso, a água remove uma espessura relativamente uniforme do solo, correspondendo à erosão por respingo ou salpicamento das partículas do solo, e a erosão em manto ou laminar, causada pelo fluxo laminar de pequena espessura e grande largura. No segundo grupo se encontram os fluxos de água em pequenos córregos, sulcos ou ravinas, e a erosão em voçorocas ou barrancos (MORGAN, 2009).

A erosão por respingo deve-se ao impacto das gotas de chuva sobre agregados instáveis de um solo exposto. Produzem-se pequenas crateras de impacto, com liberação de partículas. Seus efeitos são mais evidentes na parte de cima das vertentes, podendo dar lugar à formação de pilares ou pedestais de erosão, quando existe um agente protetor na superfície (pedras ou plantas) (CASANELLAS, 2003).

A erosão do manto ou laminar consiste na perda de uma camada mais ou menos uniforme do solo, pelo desprendimento das partículas liberadas pelos respingos, que logo são transportadas pelo escoamento, expondo o solo com possibilidades de continuar sendo erodido pelo impacto de novas gotas (CASANELLAS, 2003). Normalmente o impacto e o escoamento trabalham juntos, mas usualmente o deslocamento pelo impacto é mais fácil na parte alta da vertente, pois a medida que o escoamento move as partículas para baixo, a chuva tem que deslocar primeiro as partículas já transportadas, antes de seguir deslocando as demais. Por isso, uma erosão de manto apresenta maior dano nas partes altas, ao invés do que acontece na erosão de ravinas, onde o dano avança das partes baixas para as altas (PERALTA, 1976).

Outra consequência da erosão laminar é o selamento superficial do solo, onde as partículas finas liberadas fecham os poros deste. Isto reduz a velocidade de infiltração e a água escoa pela superfície do solo.

A erosão em ravinas se produz quando o escoamento tende a concentrar-se e formar canais cada vez maiores. À medida que a água concentra-se, vai aumentando a vazão, velocidade e quantidade de materiais em suspensão, o que dá um maior poder erosivo e transportador de partículas. A máxima erosão 
em ravinas se produz quando o escoamento contém material suficiente em suspensão, que facilita a ação abrasiva da água, permitindo extrair uma maior quantidade de partículas do solo. Este fenômeno se manifesta principalmente na parte baixa da vertente porque é o local onde chega uma maior quantidade de escoamento, com maior velocidade, concentrada e com maior quantidade de material em suspensão. Isto erode o solo com maior rapidez, gerando um desnível que aumenta o poder do fluxo, o que faz com que o material se desprenda, aumentando o tamanho das ravinas. A ravina começa então a se aprofundar até quando a ação da água no sulco encontra o material resistente do substrato ou a rocha (PERALTA, 1976).

O último tipo de erosão possível, que sucede à anterior, é a erosão de voçorocas. As voçorocas são, em geral, canais profundos, relativamente largos em relação ao fluxo que conduzem e de paredes verticais que colapsam internamente e comumente apresentam-se em áreas com subsolos profundos e frágeis (KIRKBY; MORGAN, 1980).

\subsection{Medição da erosão em campo}

Existem basicamente duas estratégias para medir a erosão em campo: determinar as mudanças do volume do solo, ou coletar sedimentos removidos para sua posterior pesagem (expressa como massa por unidade de área). Uma medição volumétrica pode se realizar com pregos de erosão, que consiste simplesmente em parcelas quadriculadas, nas quais se enterram pregos longos nos cantos de cada quadricula, que marcam o nível do solo original. Uma medição topográfica é feita no início e término do estudo ao lado do prego, obtendo uma medida para o solo perdido ou sedimentado, segundo o caso. Por um simples cálculo volumétrico se pode medir a quantidade de solo perdido (PERALTA, 1976).

O prego deve ser de uma extensão que se possa pregar $30 \mathrm{~cm}$ no solo. É preferível que tenha um diâmetro de até uns $5 \mathrm{~mm}$, já que uma largura maior pode interferir no escoamento superficial e provocar erosão (HUDSON, 1997).

Outra metodologia para registrar a espessura do solo removido, consiste em introduzir gargalos de garrafa na superfície do solo. A profundidade da erosão 
posterior se revelará por meio da altura dos pedestais onde o solo está protegido pelo gargalo da garrafa (HUDSON, 1997).

Para coletar os sedimentos removidos utilizam-se parcelas de escoamento, empregando-se para estudar os fatores que afetam a erosão, já que se podem controlar as condições em cada parcela. Cada parcela é uma porção isolada de superfície do solo que tem dados conhecidos de área, declividade, comprimento da vertente e tipo de solo (MORGAN, 2009).

Comumente utilizam-se parcelas pequenas de uns $100 \mathrm{~m}^{2}$ para testes de práticas de cultivo, efeitos de cobertura, rotações e qualquer outra prática que possa aplicar em pequenas parcelas da mesma forma que ocorre no campo, sempre que o tratamento não seja afetado pelo tamanho da parcela. Um tamanho razoável seria $5 \mathrm{~m}$ de largura e $20 \mathrm{~m}$ de comprimento (HUDSON, 1997).

Delimitam-se as parcelas para evitar o ingresso de escoamento e os sedimentos externos, e para não deixar escapar o escoamento e os sedimentos internos. As bordas ultrapassam a superfície do solo e se embutem nele até uma profundidade suficiente, fixados ao terreno. Na parte baixa da parcela coloca-se um coletor ou calha, habitualmente coberta com tampa para evitar a entrada direta de chuva. Logo, conduzem-se os sedimentos e o escoamento até os tanques ou caixas d'água. Quando os volumes de escoamento são muito altos, o volume excedente do primeiro tanque de coleta passa através de um divisor que fraciona o volume em partes iguais, e só uma fração conhecida passa, como uma amostra, a uma segunda caixa de coleta (MORGAN, 2009).

Para ter validade estatística se recomenda no mínimo três repetições por tratamento, com os experimentos distribuídos aleatoriamente. Habitualmente se estabelece um conjunto de parcelas de escoamento seguindo as curvas de nível porque desta forma evitam-se as variações correspondentes à parte superior da vertente (HUDSON, 1997).

Medem-se pelas metodologias anteriores o efeito combinado da erosão por respingo, escoamento laminar e concentrado. Para avaliar a contribuição de cada uma delas, deve-se medir independentemente. Para determinar a erosão 
por respingo, localizam-se coletores que passam 1 ou $2 \mathrm{~mm}$ por cima da superfície, eliminando deste modo a entrada de fluxo superficial. Enquanto para medição de ravinas, determina-se a seção transversal em dois pontos distanciados a uma longitude conhecida (MORGAN, 2009).

\subsection{Erosão de solos nas culturas de cana-de-açúcar e pastagem}

A cultura de cana-de-açúcar no Estado de São Paulo ocorreu sobre áreas cobertas originalmente com pastagem. ADAMI et al. (2012), analisando imagens de satélite entre os anos 2000 e 2009, determinaram que 65\% da substituição é direta, enquanto 35\% passa por um estado intermediário de culturas anuais. Estima-se que esta substituição se manterá no Estado devido à expansão da cultura de cana-de-açúcar, atingindo entre 5.330 .000 e6.800.000 hectares no ano de 2030 (OLIVETTI et al., 2011).

Apesar da grande área substituída no Estado de São Paulo, e a que resta a substituir, poucas medições e estimativas de erosão foram desenvolvidas para avaliar seu impacto.

MARTINS FILHO et al. (2009), avaliaram experimentalmente as perdas de solos e nutrientes ( $\mathrm{P}, \mathrm{K}, \mathrm{Ca}$ e $\mathrm{Mg}$ ) na cultura de cana-de-açúcar depois da colheita através da simulação de chuvas de 65 minutos, com diferentes coberturas de palha $(0 \%, 50 \%$ e $100 \%)$ sobre um Argissolo no município de Catanduva-SP. Para solo descoberto, registrou-se a erosão de 5,81 Mg.ha-1.ano-1, que foi reduzida a 1,93 e 0,77 Mg.ha-1.ano-1 para $50 \%$ e $100 \%$ de cobertura de palha, respectivamente. Da mesma forma, é registrada a redução da perda de nutrientes.

No município de Guariba-SP, SOUSA; MARTINS FILHO; MATIAS (2012) quantificaram experimentalmente a erosão num Latossolo sob plantio de canade-açúcar depois da colheita, sob chuva simulada numa vertente com três declividades diferentes $(2,5 \%, 5 \%$ e $7 \%)$ e cinco níveis de cobertura de palha (0\%, 25\%, 50\%, 75\% e 100\%). A máxima erosão ocorreu na condição de maior declividade e cobertura nula (0,096 $\left.\mathrm{Mg} \mathrm{ha}^{-1}\right)$ e a mínima na de menor declividade e maior cobertura $\left(0,001 \mathrm{Mg}^{-h^{-1}}\right)$. Os mesmos resultados foram 
descritos por (SILVA et al., 2012) no município de Pradópolis-SP num Latossolo sob chuva simulada $\left(0,001-0,095 \mathrm{Mg}^{-h^{-1}}\right)$.

Outros pesquisadores estimaram a erosão usando modelos. Assim, SPAROVEK; SCHNUG (2001) estimam as perdas de solo na cultura de cana

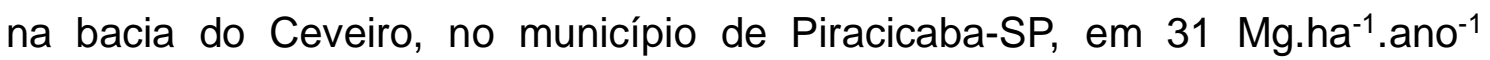
utilizando o modelo Water Erosion Prediction Project (WEPP). Na mesma bacia e utilizando a Equação Universal de Perda de Solos (USLE, siglas em inglês) estimou-se $58 \mathrm{Mg} \cdot \mathrm{ha}^{-1}$.ano-1 de perda média de solo (WEILL; SPAROVEK, 2008). Com a mesma USLE, em Catanduva-SP, estimou-se a perda de 9,64 Mg.ha-1.ano-1 em cana-de-açúcar sob Argissolo (ANDRADE et al., 2011).

Assim como para a cultura da cana-de-açúcar, existe pouca informação de campo sobre erosão de solos nas pastagens do estado de São Paulo. Segundo o estudo da Coordenadoria de Assistência Técnica Integral (CATI), desenvolvido por DRUGOWICH; SAVASTANO; LIMA SAVASTANO (2009), 0 Estado de São Paulo tem 3.688.072 hectares de pastagens sob pecuária leiteira e mista, sendo que $20 \%$ sofre degradação com a ocorrência de sulcos profundos e voçorocas, 60\% apresenta erosão laminar e ocorrência de sulcos rasos e/ou trilheiros, e somente $20 \%$ encontra-se sob manejo correto, com perdas mínimas por erosão e máxima expressão de produtividade. No estudo, usando o modelo USLE, estimou-se a perda de solo de $10 \mathrm{Mg}^{\text {ha-1 }}$.ano- $^{-1}$ nas áreas com maior degradação, até o mínimo de 0,19 Mg.ha-1.ano-1, somando uma perda total de 11.219.826 Mg.ano-1 de solos no estado. Outro valor, estimado com o modelo USLE por SILVA et al. (2005), para uma microbacia no município de Cunha-SP, chega até $28 \mathrm{Mg} \cdot \mathrm{ha}^{-1}$.ano-1 em Latossolos cobertos com pastagens.

Como as avaliações de erosão para as culturas de cana-de-açúcar e pastagens no estado de São Paulo foram feitas sob diferentes condições de chuva e solos, os resultados não são comparáveis entre si, impedindo de se avaliar com confiança a variação da erosão na substituição de pastagens pela cultura da cana-de-açúcar. Ademais, os modelos existentes foram desenvolvidos para solos e condições climáticas distintas das observadas em São Paulo e, uma vez aplicados localmente, não foram calibrados com valores de erosão medidos em campo ou representam medições pontuais de 
simulações que não consideram as variações anuais (BRAMORSKI et al., 2012). Como resultado, não há consenso sobre a dimensão do problema erosivo e os modelos não podem ser aplicados em condições diferentes com resultados confiáveis.

\subsection{Balanço hídrico nas culturas de cana-de-açúcar e pastagem}

SALAS (1987) identifica como principais termos no balanço hídrico a precipitação, a interceptação da folhagem, o escoamento, a infiltração, a percolação, a evaporação, a transpiração e o armazenamento da água no perfil do solo. FELLER (1981) apud ECHEVERRÍA; HUBER; TABERLET (2007) estabelece a equação do balanço hídrico baseado na metodologia de continuidade de massa:

$$
E T P=P P-I C-\Delta W-E s-P e r \quad(\text { Equação 1) }
$$

onde ETP é a evapotranspiração, PP é a precipitação, IC é a interceptação da folhagem, $\Delta \mathrm{W}$ é a água armazenada no solo, Es é o escoamento superficial e Per é a percolação. Todas as variáveis são expressas em mm.

Além das perdas de solo, a substituição de culturas produz a modificação do balanço hídrico deste, especialmente pela interceptação da folhagem, demanda hídrica específica da cultura e profundidade das raízes, onde a planta extrai a água para transpiração.

Para a cultura de cana-de-açúcar no Estado de São Paulo, existem poucos estudos feitos para determinar seu balanço hídrico e nenhum para determinar as mudanças causadas pela substituição de pastagens.

Em Piracicaba-SP, TIMM et al. (2002) mediram a chuva enquanto a evapotranspiração, escoamento superficial, percolação e água armazenada até $1 \mathrm{~m}$ de profundidade de terra roxa estruturada foram calculados. O período de estudo (novembro a março) foi desde o estado inicial da cultura até as plantas terem coberto completamente o solo, avaliando as variáveis de estudo com e 
sem resíduos de palha e resíduos da queima, não achando diferenças significativas entre os tratamentos.

Outro estudo, (BRITO; LIBARDI; GHIBERTO, 2009) desenvolvido nos municípios de Jaboticabal e Pirassununga-SP, quantificou a precipitação e a água armazenada no solo, tendo calculado a drenagem interna e a evapotranspiração entre os meses de setembro de 2005 e julho de 2006. Os tratamentos avaliados foram cana-de-açúcar com diferentes doses de adubação nitrogenada, sem diferença significativa nos resultados. Em Jaboticabal-SP, GHIBERTO et al. (2011) quantificaram o balanço hídrico depois do primeiro corte em cana-de-açúcar entre os meses de novembro de 2006 e julho de 2007, sob três tratamentos com diferentes doses de nitrogênio e enxofre. Foi medida a precipitação, enquanto as variações de umidade do solo foram determinadas pelo método gravimétrico. A drenagem interna e a ascensão capilar foram calculadas pela equação de Darcy-Buckingham, com profundidade máxima de 0,9 m. A evapotranspiração foi calculada pela diferença dos valores anteriores, desprezando escoamento e interceptação. A mencionada pesquisa não achou diferença significativa entre os tratamentos, pelo contrário, obteve grande variação na estimativa de drenagem e, consequentemente, nos outros componentes do balanço hídrico.

A fração de chuva que constitui o escoamento tem sido medida em alguns dos estudos de erosão em cana-de-açúcar. SILVA et al. (2012) avaliaram o efeito da palha na redução do escoamento num Latossolo em Pradópolis-SP, concluindo que eles são inversamente proporcionais sob chuva simulada de 65 $\mathrm{mm} \cdot \mathrm{h}^{-1}$ em 60 minutos.

Com o intuito de quantificar a interceptação da cana-de-açúcar, CASTILHO (2000), no município de Campinas-SP, determinou experimentalmente que somente $60 \%$ da precipitação total atingiu o nível do solo durante os 10 meses de estudo.

Embora existam poucos estudos do balanço hídrico para a cultura de canade-açúcar no Estado de São Paulo, não há estudos antecedentes sob a cobertura de pastagem. 


\section{MATERIAL E MÉTODOS}

\section{1 Área de estudo}

O experimento foi desenvolvido na fazenda São José, propriedade da Conquista Agropecuária, no município de Itirapina-SP, coordenadas UTM WGS 1984, 23k 205802E - 7543956S, 790 m de altitude (Figura 1). O clima local é considerado como tropical de altitude (Cwa, segundo a classificação de Köppen), clima quente com inverno seco. A precipitação média anual (entre 1961 e 1990) é de 1.548 mm.ano-1, medida na estação meteorológica de São Carlos (código OMM 83726, instalada na Universidade Federal de São Carlos), distante $20 \mathrm{~km}$ da área de estudo (INMET, 2013). O período chuvoso é de outubro a março.

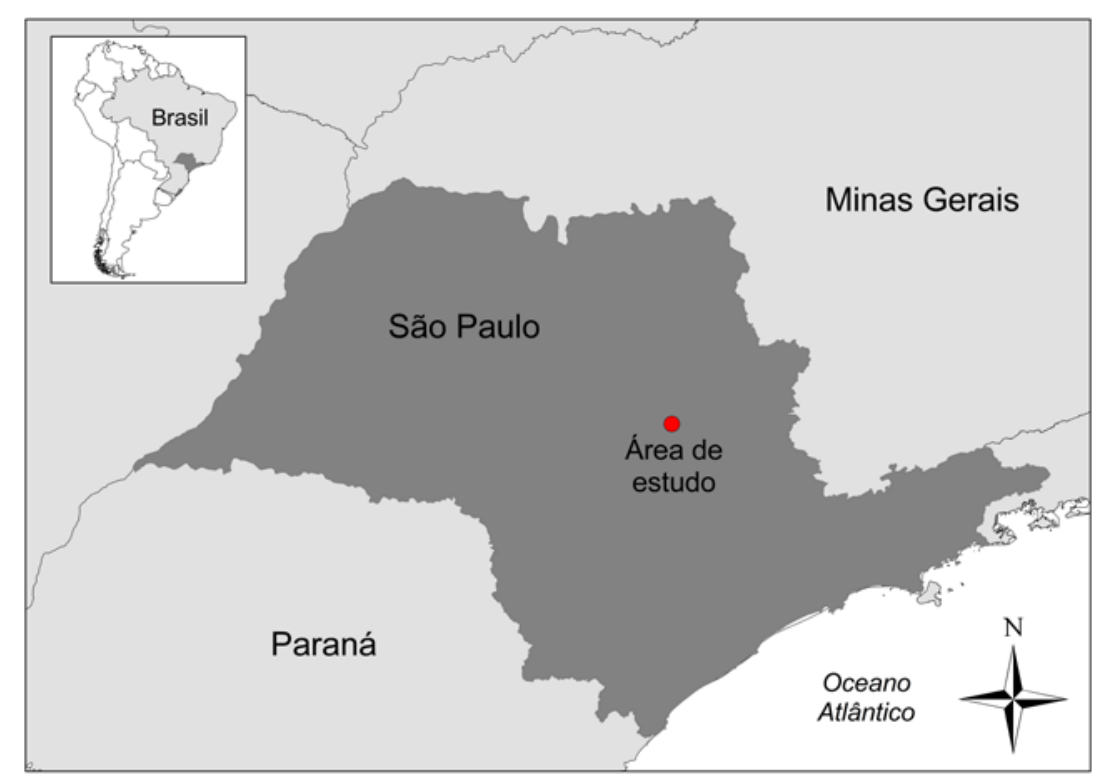

Figura 1 - Localização da área experimental no estado de São Paulo.

Do ponto de vista hidrográfico, a área de estudo localiza-se na micro-bacia do Ribeirão do Feijão, na Sub-Bacia do Rio Jacaré-Guaçu, Unidade de Gerenciamento de Recursos Hídricos 13 - UGRHI 13 da Bacia Hidrográfica do Tietê-Jacaré. A topografia da região é ondulada, originalmente vegetada por cerrado, porém atualmente coberta por pastagem para produção de gado de corte. O solo é do tipo Neossolo Quartzarênico, representativo para a região 
Oeste do estado de São Paulo (áreas de ocorrência dos sedimentos do Grupo Bauru), de textura arenosa (85\% areia, 12\% argila e 3\% silte). Os parâmetros físicos do solo (análise granulométrica pelo método do densímetro e classe de diâmetro U.S.D.A., retenção de água no solo, porosidade, densidade e condutividade hidráulica) a 30, 60 e $90 \mathrm{~cm}$ de profundidade foram determinados no laboratório de solos da Escola Superior de Agricultura "Luiz de Queiroz", USP-Piracicaba, e são apresentados no Anexo 1.

\subsection{Registro das precipitações}

As chuvas no local foram registradas com uma estação meteorológica automática, marca Campbell, com uma resolução de $0,2 \mathrm{~mm}$ e programada para registrar as precipitações em intervalos de 10 minutos (Figura 2). O registro das precipitações começou no dia 13 de outubro de 2011, com a instalação da estação na área de estudo. Precipitações separadas por intervalos de 6 horas são consideradas eventos independentes (WISCHMEIER; SMITH, 1978).

Além das precipitações, a estação meteorológica registra temperatura e umidade do ar, direção e velocidade do vento, radiação solar, pressão atmosférica, nível freático de poço de monitoramento e umidade do solo até 90 $\mathrm{cm}$ de profundidade (detalhes do sensor na página 22).

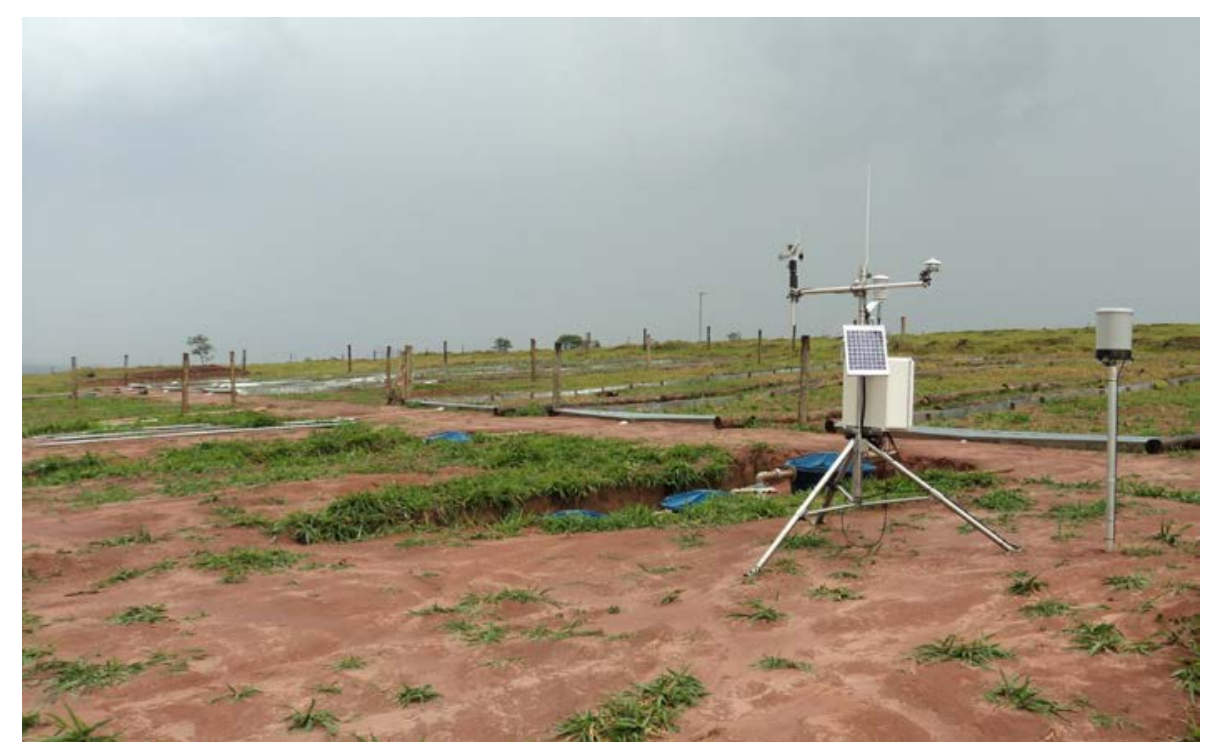

Figura 2 - Estação meteorológica instalada na área de estudo, ao lado das parcelas com pastagem. 
Os dados meteorológicos são transmitidos em tempo real via modem a um servidor do Laboratório de Hidráulica Computacional-SHS-EESC, podendo ser acessados livremente no endereço http://www.lhc.shs.eesc.usp.br/node/39 (Anexo 2).

\subsection{Culturas e tratamentos}

Os tratamentos avaliados foram pastagem e cana-de-açúcar num talhão vertente com $9 \%$ de declividade, exposição Norte. A invernada tem pastagem para gado de corte (Brachiaria decumbens), semeada há mais de 18 anos sob pastoreio com rotação a cada 30 dias, permanência de 50 animais por 5 hectares durante 5 dias, e altura de pasto entre 5 e $30 \mathrm{~cm}$. Em um setor da invernada estabeleceu-se um plantio novo de cana-de-açúcar (Saccharum officinarum) em uma área de $625 \mathrm{~m}^{2}(25 \times 25 \mathrm{~m})$, em curvas de nível distanciadas de 1,5 m (17 sulcos). O plantio foi realizado no dia 27 de outubro de 2011, depois das primeiras precipitações no início da temporada chuvosa e após o preparo do solo com gradeamento mecanizado. Por este motivo, corresponde a plantio de primavera, com um ciclo de plantio-colheita de 12 meses e uma produção esperada de 80 t.ha ${ }^{-1}$. Controlou-se a aparição de ervas daninhas mediante capina manual, deixando o solo exposto sob a canade-açúcar. Após a colheita (01 de novembro de 2012), o solo foi gradeado manualmente entre-sulcos, com disposição de linhas de palha a cada três entre-sulcos de cana-soca, segundo manipulação padrão dos plantios comerciais para produção de etanol. Os trabalhos realizados para estabelecer e explorar o plantio de cana-de-açúcar apresentam-se documentados fotograficamente no Anexo 3.

A área experimental foi protegida com uma cerca tipo paraguaia de 5 fios de arame liso para evitar o ingresso do gado no plantio de cana-de-açúcar, na área com a estação meteorológica e no sistema de coleta do escoamento e sedimentos.

Para efeitos da presente pesquisa, o primeiro ano de medições vai desde o plantio (27 de outubro de 2011, cana-planta) até sua primeira colheita (01 de novembro de 2012), enquanto o segundo período (cana-soca) vai desde sua colheita até 30 de abril de 2013, após o fim da temporada chuvosa. 


\subsection{Monitoramento de escoamento e erosão de solos}

Nas áreas de cana-de-açúcar e pastagem, foram construídas parcelas de escoamento (20x5 $\mathrm{m}^{2}$ ), segundo as indicações de VEIGA; PRADO (1993), com três repetições para cada tratamento (Figura 3). As parcelas delimitam a área com chapas metálicas soterradas parcialmente no solo e, no caso da área de pastagem, reforçadas com mourões para resistir ao passo do gado (Figura 4a e 4b). As parcelas conduzem o escoamento superficial até um coletor (tipo funil de $5 \mathrm{~m}$ de comprimento) e um sistema de três caixas d'água (310 L), onde é armazenado o escoamento de cada chuva. Entre as caixas d'água foram instaladas caixas sifonadas com sete saídas em nível sobre uma plataforma ajustável, conectando só uma das saídas à caixa d'água seguinte (Figura 5). Assim, as caixas sifonadas atuam como divisores do escoamento, aumentando o volume total que o sistema pode armazenar (equivalente a $300 \mathrm{~L}$ na caixa 1 , $2.100 \mathrm{~L}$ na caixa 2 e $14.700 \mathrm{~L}$ na caixa 3 , somando mais de $17.000 \mathrm{~L}$ de escoamento capaz de ser armazenado).
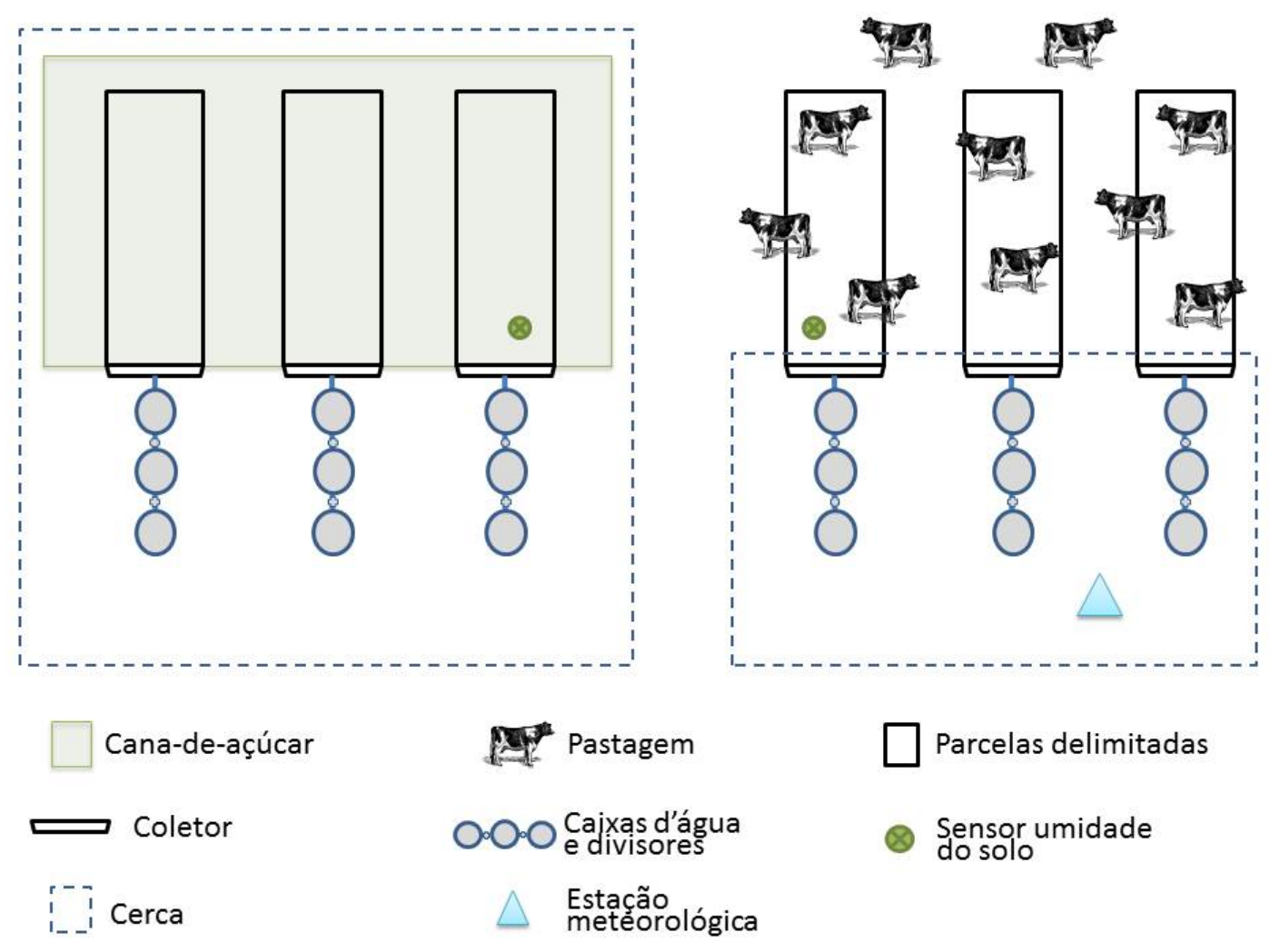

Figura 3 - Esquema da distribuição das parcelas de escoamento e sensores segundo tratamento. 

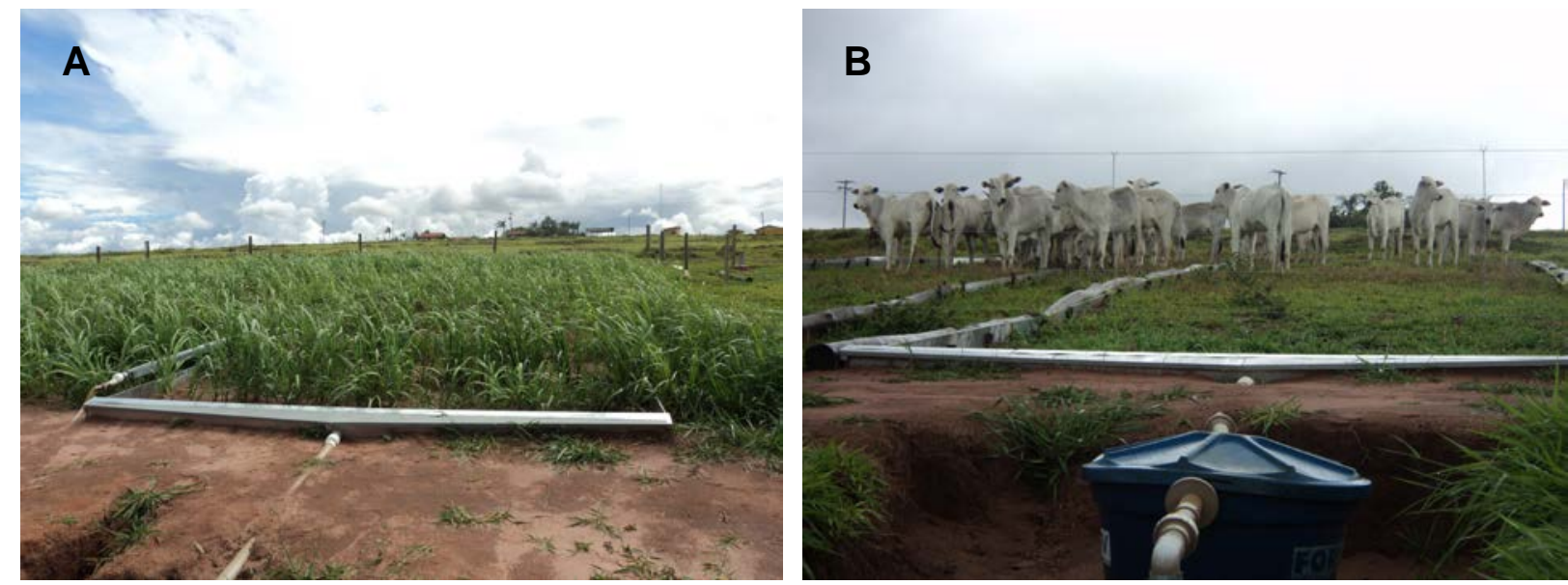

Figura 4 - a) Parcela sob cana-de-açúcar; e, b) Parcela sob pastagem. Observa-se os coletores e caixa d'água.

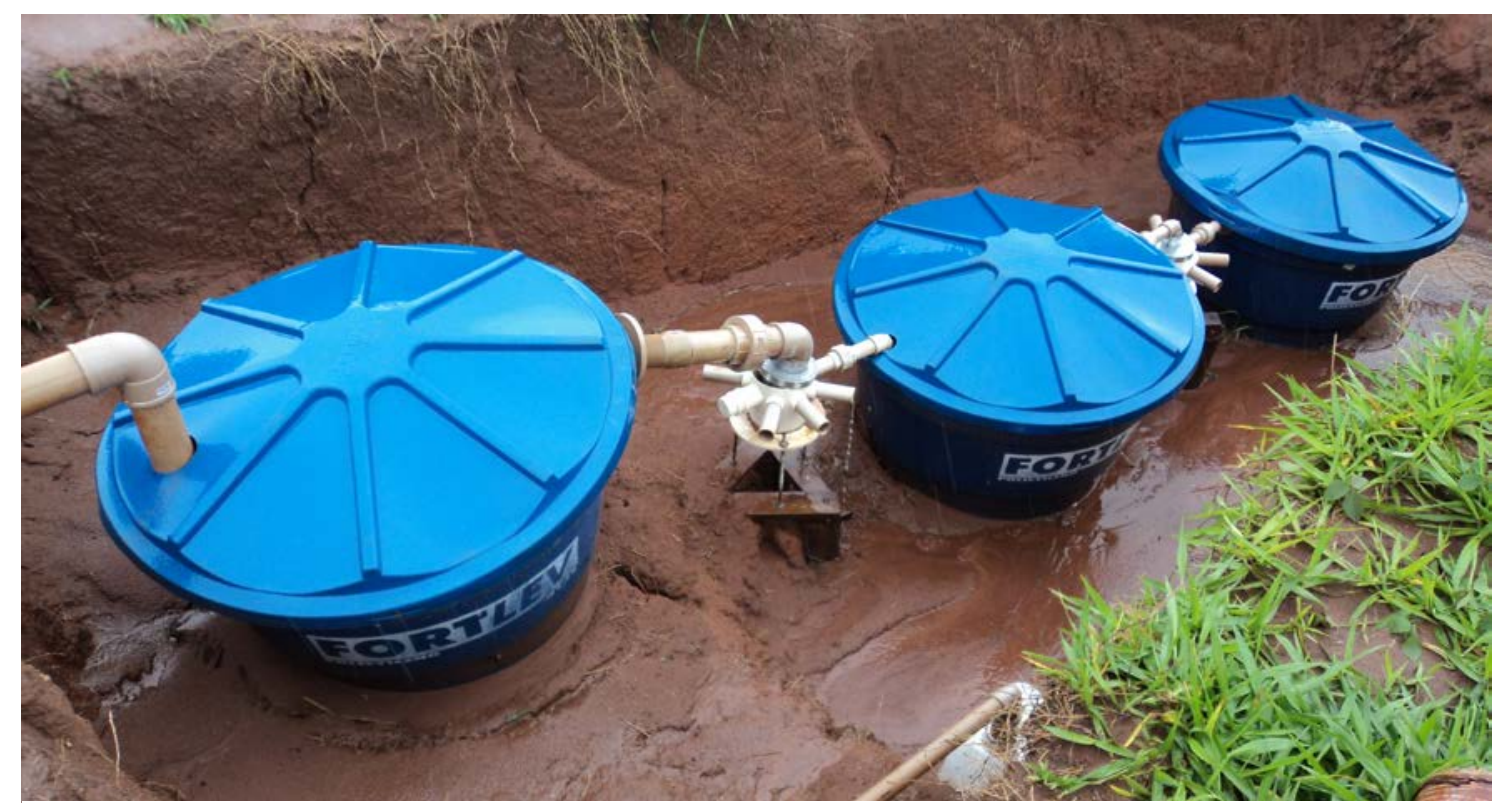

Figura 5 - Conjunto de caixas d'água e divisores para armazenamento do escoamento e sedimentos.

Depois de cada evento de chuva, os sedimentos sólidos retidos no coletor (principalmente partículas grossas) foram recolhidos com espátula e guardados em sacolas plásticas para posterior secagem e pesagem em laboratório (Figura 6). Nas caixas d'água que continham o escoamento e sedimentos (principalmente partículas finas em suspensão), foi registrado o volume escoado, usando uma curva de calibração altura-volume previamente estabelecida em laboratório (Anexo 4). Em seguida, o volume armazenado era 
agitado vigorosamente para suspender os sedimentos do fundo, sendo coletado 1 litro de amostra em garrafa plástica devidamente rotulada (Figura 7).

Em laboratório foi determinado o peso seco dos sedimentos utilizando uma balança digital marca Quimis com precisão de 0,01 g após a secagem das amostras em estufa a $105^{\circ} \mathrm{C}$ por 24 horas, tanto para as amostras de escoamento com sedimentos em suspensão como para as amostras de sedimentos coletados do coletor. Após a análise de laboratório, os resultados de sedimentos foram totalizados, de acordo com o volume total escoado e a área total das parcelas.

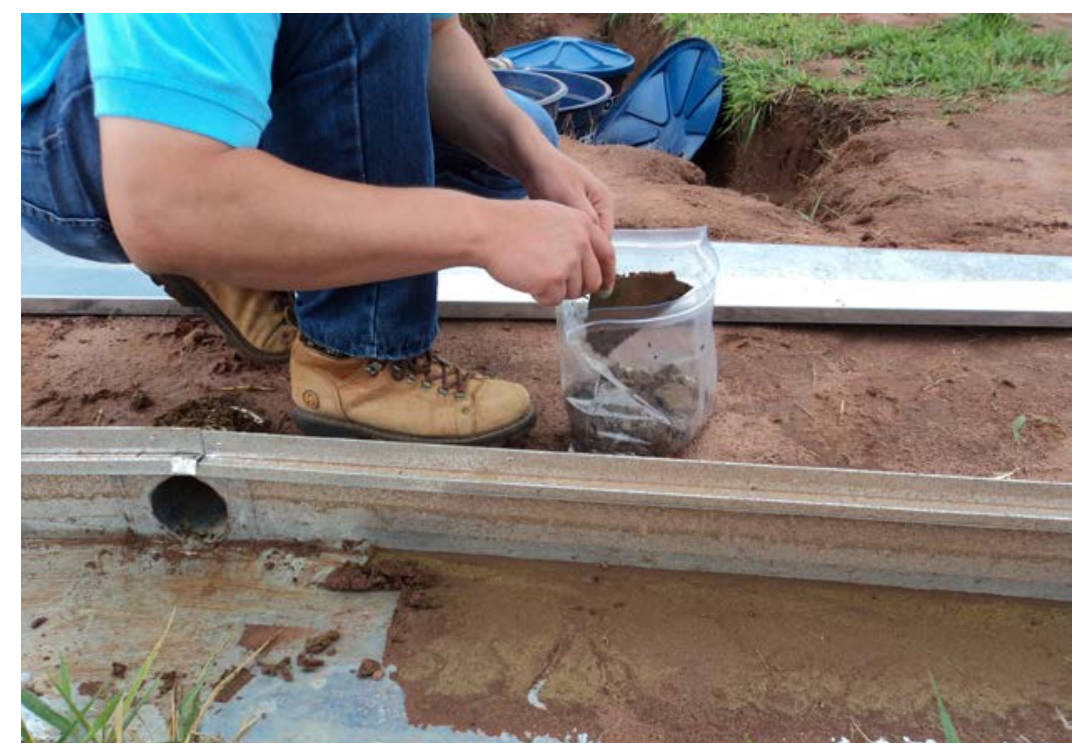

Figura 6 - Coleta dos sedimentos grossos do coletor, usando espátula, escova e sacolas plásticas rotuladas. 


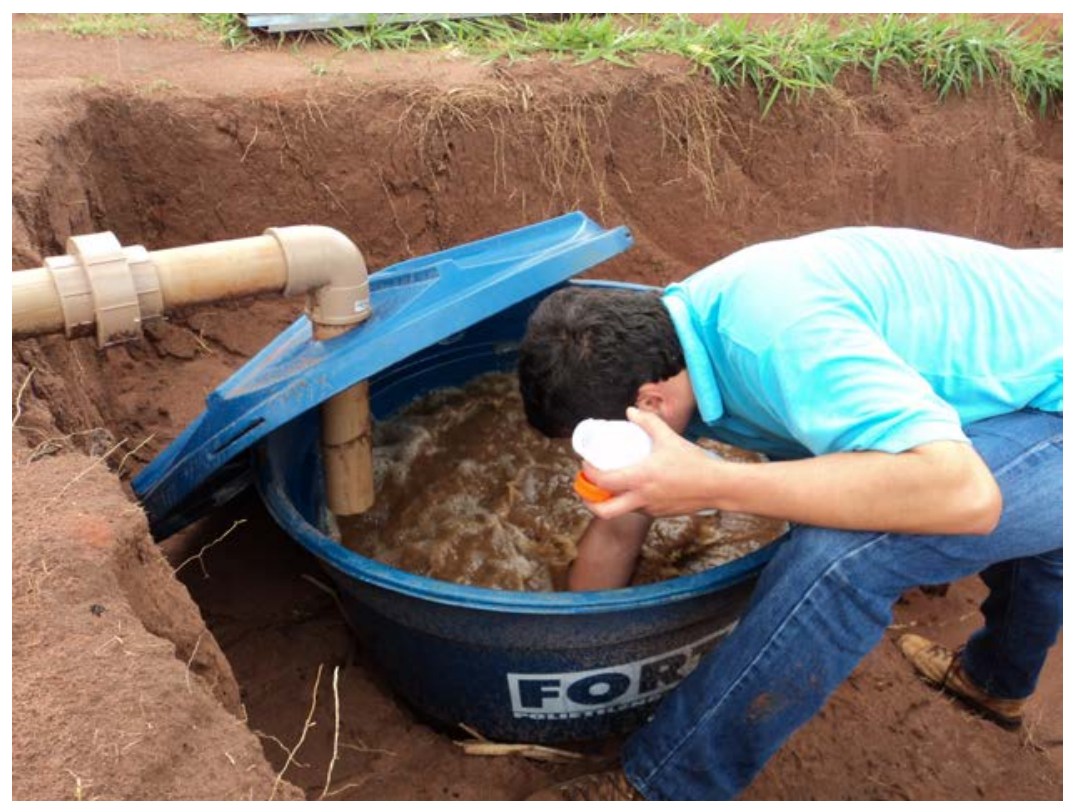

Figura 7 - Coleta de amostras de escoamento e sedimentos finos em garrafa plástica das caixas d'água, após homogeneização do escoamento.

\subsection{Balanço hídrico}

No presente estudo foi utilizada a equação 1 para determinar o balanço hídrico. A precipitação foi medida em mm/evento com o pluviômetro da estação meteorológica instalada na área experimental (Figura 2). A interceptação em cana-de-açúcar foi estimada pela diferença entre o registro pluviométrico e a chuva que atinge o solo sob a cobertura. Dita fração é coletada com calhas de chapa metálica de $3 \mathrm{~m}$ de comprimento, 0,12 m de largura e $8 \mathrm{~cm}$ de altura, fixada com suportes de aço $15 \mathrm{~cm}$ acima do nível do solo, em três repetições dispostas perpendicularmente às três primeiras linhas de cana-de-açúcar e conectadas a um galão de $20 \mathrm{~L}$ (Figura 8). Depois de cada evento gerador de escoamento, é medido o volume de água do galão e calculada a lâmina (mm/evento) que atingiu o solo, dividindo o valor medido por um fator de 0,39 (resultante da área da calha que recebe a precipitação e ajustado em campo com as primeiras medições sem cobertura). Em pastagem não se considerou interceptação devido à baixa altura da cobertura $(5-30 \mathrm{~cm})$ comparada com cana-de- açúcar. 


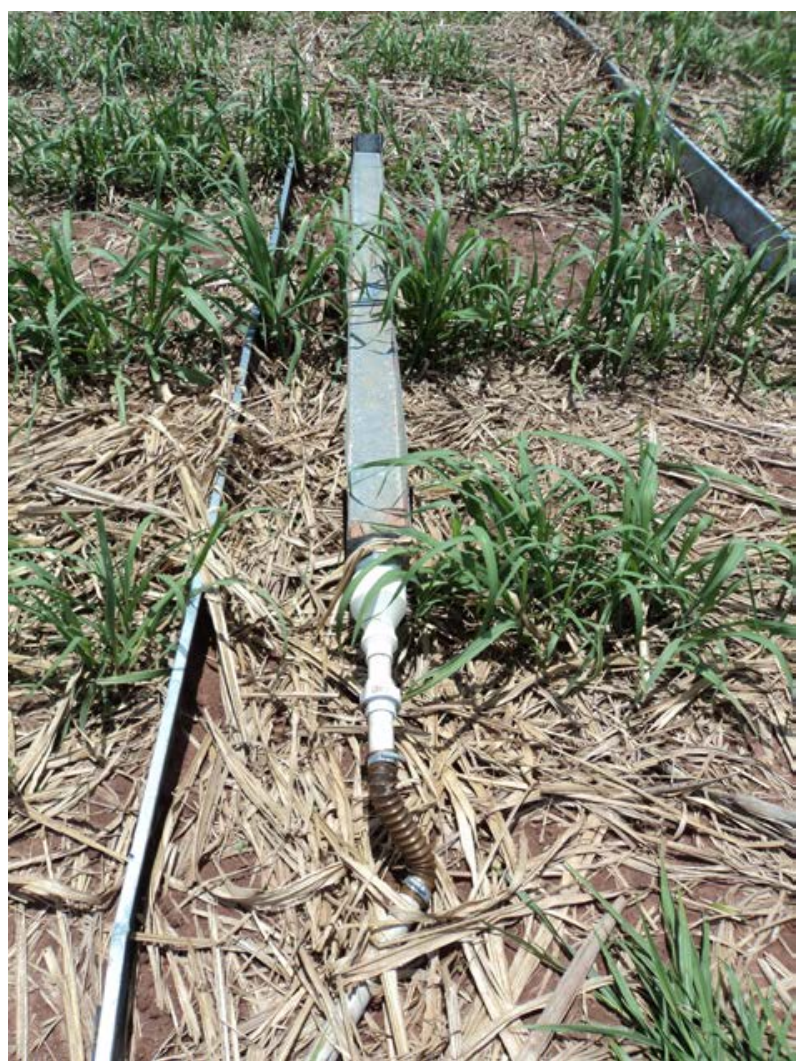

Figura 8 - Calha d'água para medição da interceptação. A calha recebe a fração da chuva que atinge o solo, e armazena seu volume em um galão no outro extremo do tubo de PVC.

A água armazenada no solo $(\Delta \mathrm{W})$ é medida com o sensor de umidade marca Sentek, modelo EnviroScan, baseado no principio da capacitância de alta frequência. O instrumento é constituído por um tubo de acesso fixado no solo com 1,2 m de profundidade e sensores ajustáveis a cada $10 \mathrm{~cm}$ (Figura 9). No presente estudo, os sensores foram dispostos a 30, 60 e $90 \mathrm{~cm}$ de profundidade, conectados à estação meteorológica e programados para efetuar leituras com frequência de 10 minutos, tanto em um ponto de pastagem como em cana-de-açúcar. 


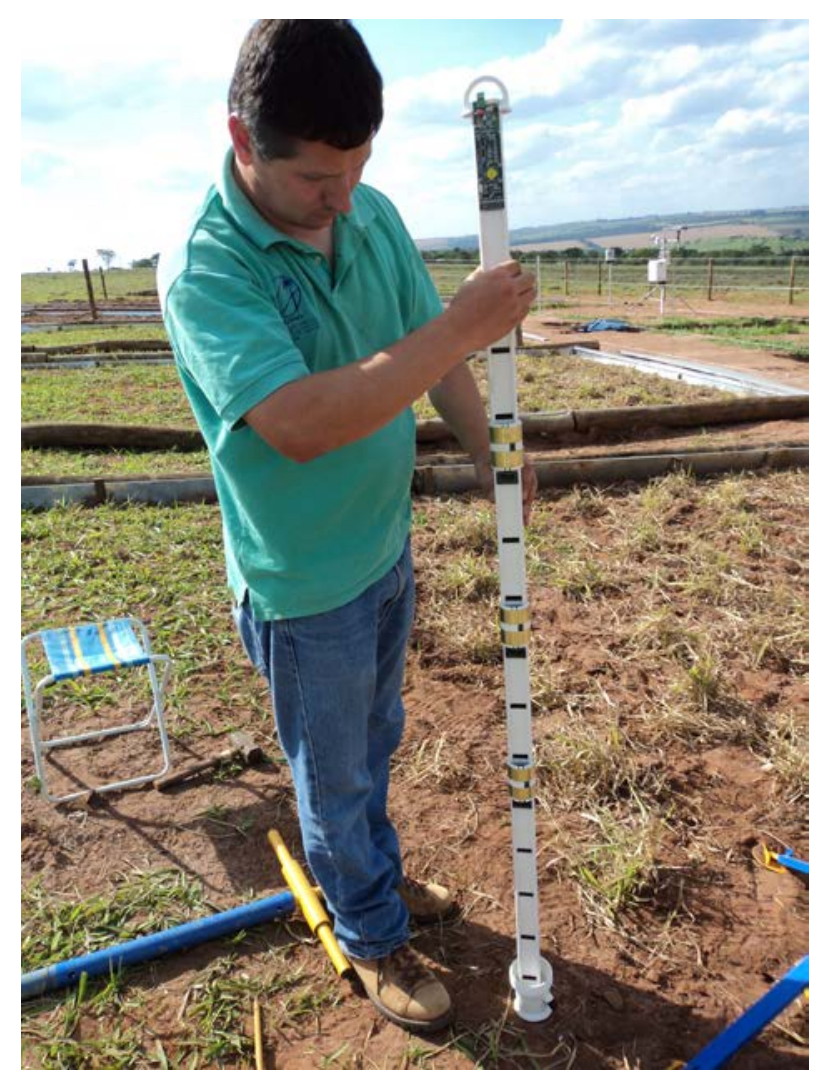

Figura 9 - Instalação do sensor de umidade marca Sentek, modelo EnviroScan, no tubo de acesso na parcela de pastagem.

O sensor foi calibrado para o solo local, seguindo as indicações do fabricante (SENTEK, 2011), obtendo-se os coeficientes de ajuste apresentados no Anexo 5. Com os valores de umidade de solo em diferentes profundidades expressos em \%, calculou-se a lâmina d'água contida no perfil até $1 \mathrm{~m}$ de profundidade, utilizando o método do trapézio (LIBARDI, 2005):

$$
\Delta W(m m)=\left[\left(\left(\frac{w 30}{2}+w 60+\frac{w 90}{2}\right) \times 0,3\right)+(w 30 \times 0,3)\right] \times 10 \quad \text { (Equação 2) }
$$

onde $w$ é a umidade do solo em \% nas profundidades 30,60 e $90 \mathrm{~cm}$. Uma vez calculado o conteúdo de água no primeiro metro de profundidade do solo em $\mathrm{mm}$ a intervalos de 10 minutos, obtém-se a variação diária para ambas coberturas, expressa em mm.dia ${ }^{-1}$. 
A evapotranspiração potencial (ETo) foi estimada diariamente segundo a equação de Penman-Monteith, publicada no Boletim 56 da série Irrigação e Drenagem da FAO (ALLEN et al., 1998), usando os dados da estação meteorológica instalada na área experimental. Para calcular a evapotranspiração da cultura (ETC), a ETo é multiplicada pelo coeficiente da cultura $(K c)$. Este coeficiente para pastagem foi obtido do mesmo boletim 56 $\left(K c_{\text {pastagem }}=0,75\right)$, enquanto para cana-planta foi obtido do boletim 33 (DOORENBOS; KASSAM; BENTVELSEN, 1979) e para cana-soca foi obtido do boletim 24 (DOORENBOS; PRUITT; ABOUKHALED, 1975) da mesma série FAO, apud BARROS (2011) (Tabelas 1 e 2, respectivamente). Estes valores internacionais foram assumidos, uma vez que não há consenso nas poucas referências nacionais para o valor de Kc para cana-de-açúcar (LYRA et al., 2012; DA SILVA et al., 2013).

Tabela 1 - Valores de Kc para cana-planta.

\begin{tabular}{lll}
\hline Idade da cana (dias) & Período de desenvolvimento & Kc \\
\hline $30-60$ & Do plantio até 25\% de cobertura & $0,40-0,60$ \\
$30-40$ & De 0,25\% a 0,50 de cobertura & $0,75-0,85$ \\
$15-25$ & De 0,50 a 0,75 de cobertura & $0,90-1,00$ \\
$45-55$ & De 0,75 à cobertura completa & $1,00-1,20$ \\
$180-330$ & Utilização máxima & $1,05-1,30$ \\
$30-150$ & Início da senescência & $0,80-1,05$ \\
$30-60$ & Maturação & $0,60-0,75$ \\
\hline
\end{tabular}

Fonte: DOORENBOS; KASSAM; BENTVELSEN (1979)

Tabela 2 - Valores de Kc para cana-soca

\begin{tabular}{lll}
\hline Idade da cana (dias) & Estágio de desenvolvimento da cultura & Kc \\
\hline 30 & Do plantio até 25\% de cobertura do solo & 0,55 \\
30 & De 25 a $50 \%$ de cobertura do solo & 0,80 \\
15 & De 50 a 75\% de cobertura do solo & 0,90 \\
45 & De 75 a 100\% de cobertura do solo & 1,00 \\
180 & Cobertura total do solo & 1,05 \\
30 & Início da maturação & 0,80 \\
30 & Maturação & 0,60 \\
\hline
\end{tabular}

Fonte: DOORENBOS; PRUITT; ABOUKHALED (1975) 
Uma vez que a evapotranspiração real diária das culturas não pode ser maior que a oferta diária de água no solo (equação 3 , variação de $\Delta W$ ), estabeleceu-se a restrição de que, caso isto ocorresse, a evapotranspiração tomaria o valor da variação da umidade do dia menos o infiltrado no mesmo dia, se houver, (equação 4). Assim obteve-se um valor de evapotranspiração real ou corrigido, expresso em mm.dia ${ }^{-1}$.

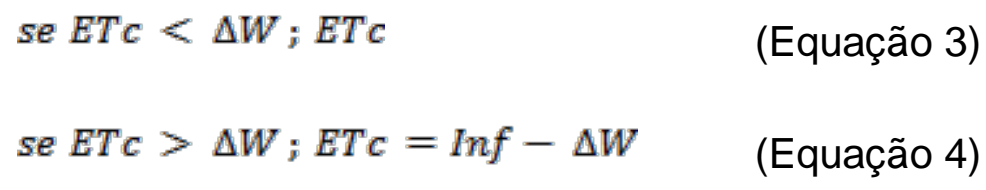

Finalmente, o escoamento superficial foi medido diretamente nas caixas d'água e a percolação calculada pela diferença de todas as variáveis anteriores, sendo a incógnita da equação 1. Ambas variáveis foram expressas em mm.dia ${ }^{-1}$.

\subsection{Analise estatística}

Para determinar se a diferença na produção de escoamento e sedimentos, entre os tratamentos, foi estatisticamente significativa (nível de significância ou probabilidade de erro, $\mathrm{P}<0,05)$ aplicou-se uma análise não paramétrica de Mann-Whitney e calculou-se a média e desvio padrão das três repetições de cada tratamento usando o software Minitab16 (Minitab Inc., 2010). 


\section{RESULTADOS E DISCUSSÃO}

\subsection{Precipitações}

A estação meteorológica começou a registrar as precipitações a partir do evento de 13 de outubro de 2011. O menor evento foi de 0,2 mm, enquanto o maior foi de $96,3 \mathrm{~mm}$. Durante o primeiro ano hidrológico do experimento (outubro 2011 - setembro 2012), aconteceram 118 precipitações que totalizaram $1.253 \mathrm{~mm}$. Nos primeiros sete meses do segundo ano hidrológico estudado (outubro 2012 - abril 2013) aconteceram 97 precipitações, acumulando $857 \mathrm{~mm}$. O primeiro período apresentou valor abaixo da média anual que é $1.548 \mathrm{~mm}$; já o segundo período, ainda não está fechado (Figura 10). Comparando somente os períodos chuvosos (outubro até março), o primeiro ano teve 76 eventos (839 mm), enquanto o segundo período teve 89 eventos $(788 \mathrm{~mm})$. Ao comparar estatisticamente as duas temporadas chuvosas, através da análise não-paramétrica de Mann-Whitney, pode-se afirmar que não existem diferenças no padrão de chuvas em relação a pluviometria $(P=0,5453)$, intensidade $(P=0,3990)$ e frequência $(P=0,9172)$. $O$ maior período de seca no período estudado aconteceu de 17 de julho a 20 de setembro 2012 (65 dias).

\subsection{Escoamento}

As medições de escoamento superficial e das outras variáveis avaliadas neste estudo consideram um ciclo anual que começa em 1 de novembro de 2011, logo após a construção das parcelas em cima do plantio de cana-deaçúcar, e termina após a colheita da cana em 1 de novembro 2012. Por este motivo, os resultados apresentaram uma defasagem de um mês em relação ao ano hidrológico avaliado, o que explica as diferenças com os valores que serão apresentados em seguida.

Nem todas as chuvas geraram escoamento, e quando geram nem sempre acontecia simultaneamente nos dois tratamentos. Das 122 chuvas $(1.270 \mathrm{~mm})$ que aconteceram no primeiro ciclo anual, somente 37 eventos produziram 


\section{PRECIPITAÇÃO}

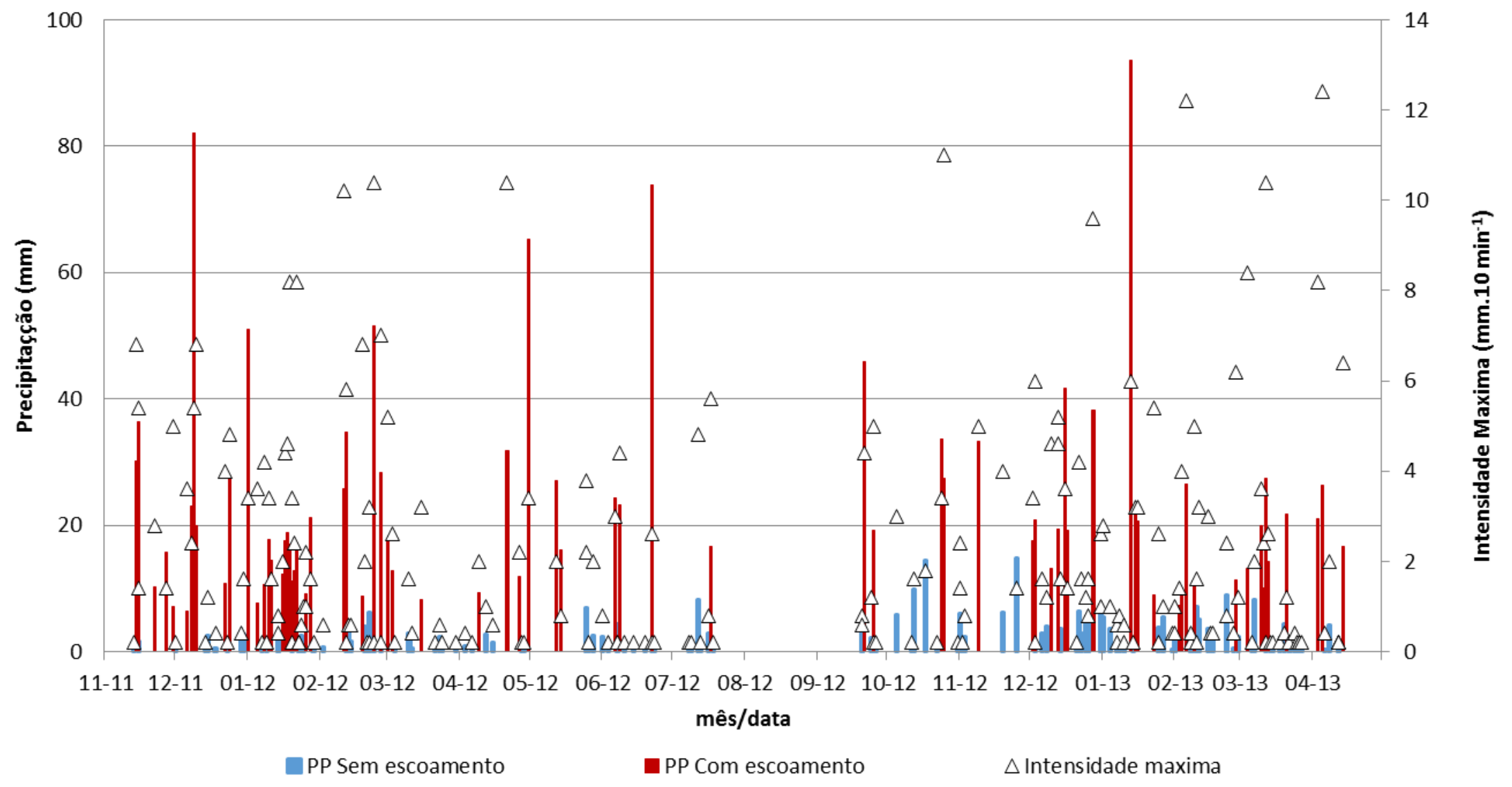

Figura 10 - Registro dos eventos de precipitação $(\mathrm{mm})$ e sua intensidade máxima em 10 minutos (mm.10min $\left.{ }^{-1}\right)$. Barras azuis indicam eventos sem escoamento e barras vermelhas indicam eventos geradores de escoamento. 
escoamento na pastagem (somando $1.058 \mathrm{~mm}$ de escoamento), e apenas 48 eventos na cana-de-açúcar (1.147 mm de escoamento). Já nos primeiros seis meses do segundo ciclo anual, das 88 chuvas totais $(762 \mathrm{~mm}$ ) apenas 26 eventos (591 mm) apresentaram escoamento na pastagem e 27 eventos (600 $\mathrm{mm}$ ) na cana-de-açúcar (Figura 10). O menor evento que gerou escoamento foi de $6 \mathrm{~mm}$. Todos os eventos com intensidade acima de $5 \mathrm{~mm} .10 \mathrm{~min}^{-1}$ ou 15 $\mathrm{mm}$ de lâmina total geraram escoamento superficial. As primeiras chuvas no fim do período seco 2012 não geraram escoamento (9,8 e 14,4 mm).

Nas Figuras 11 e 12 apresentam-se os resultados de escoamento médio registrado por evento e mensalmente nas parcelas e a precipitação que a gerou (dados individuais apresentam-se no Anexo 6). As colunas representam um evento individual, com exceção dos eventos sucessivos quando o intervalo de 6 horas aconteceu durante a noite, impossibilitando sua coleta como eventos independentes. Essa situação ocorreu em 10 de dezembro de 2011, 11 de janeiro, 14 de maio, 8 de junho, 3 e 17 de dezembro de 2012, 4 de fevereiro e 11 de março de 2013.

Os eventos com maior escoamento aconteceram em situações de: i) alta pluviometria (lâmina por evento) durante o período chuvoso (10 de dezembro de 2011, 23 de fevereiro e 28 de dezembro de 2012, 13 de janeiro de 2013); ii) períodos de chuvas muito frequentes (16 a 22 de janeiro 2012); ou, iii) eventos de alta intensidade (12 de fevereiro, 21 de abril, 25 de outubro 2012, 6 de fevereiro, 12 de março e 3 de abril de 2013). Os valores de escoamento registrados nos eventos de alta intensidade são muito próximos entre eles sem a presença da palha na cana-de-açúcar durante o primeiro ano.

De modo geral, no gráfico por evento (Figura 11) e mensal (Figura 12) pode-se observar que no primeiro ciclo anual, o escoamento na cana-de-açúcar foi maior que na pastagem (exceto para as duas primeiras chuvas, produto da perturbação do solo durante o plantio da cana). No segundo ano, a situação inverteu-se devido à disposição da palha a cada três entre-sulcos. Assim, durante o primeiro ano na pastagem escoou 40,5 mm (3,6\% da lamina total de eventos que geraram escoamento) e na cana-de-açúcar escoou 56,1 mm (5,0\%). Já no segundo período, na pastagem escoou 30,4 mm (5,1\%), e na cana-de-açúcar 11,8 mm (2,0\%) da precipitação que gerou escoamento. 
PP, ESCOAMENTO E INTERCEPTAÇÃO POR EVENTO

\section{Data}

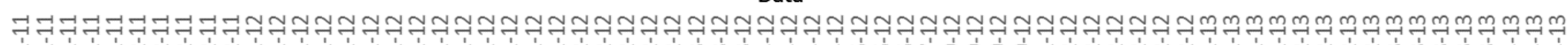

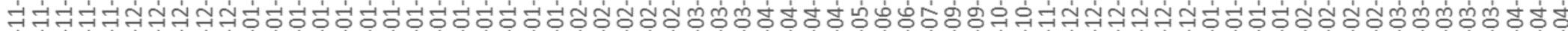

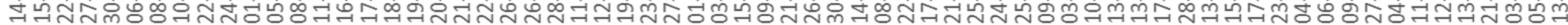

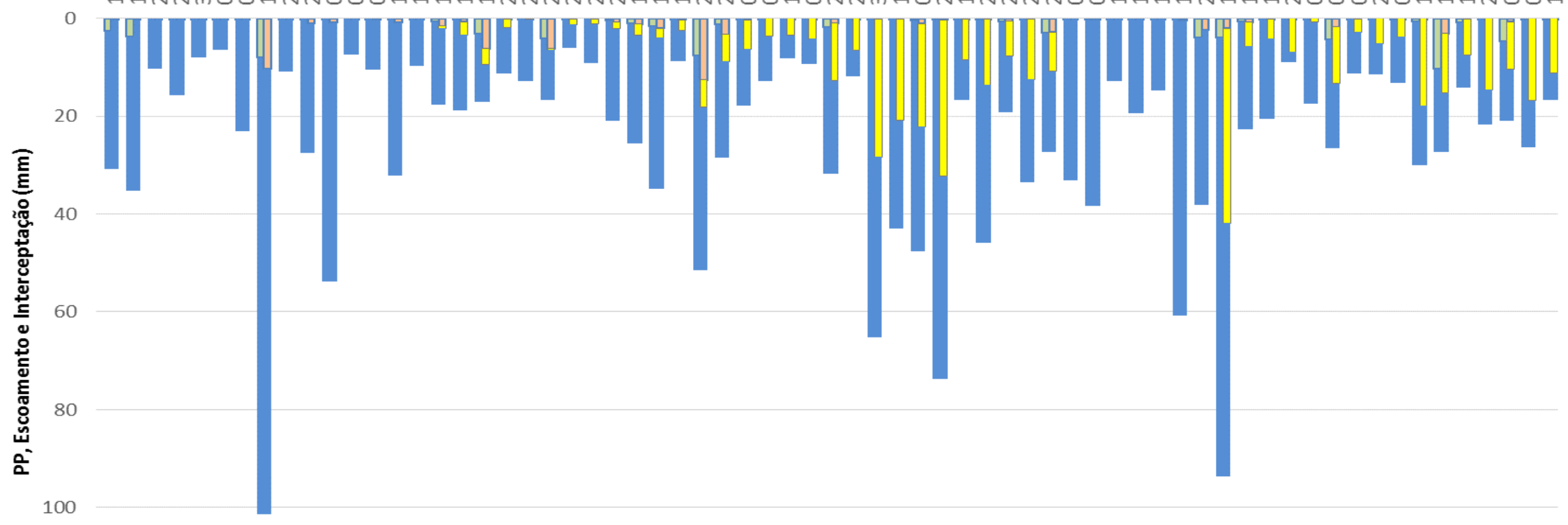

120

$$
\text { 口Pastagem Escoamento } \quad \square \text { Cana de açúcar Escoamento } \square \text { Cana de açúcar Interceptação } \quad \text { DP Total }
$$

Figura 11 - Escoamento superficial, interceptação, e precipitação total por evento e cultura. 
PRECIPITAÇÃO, INTERCEPTAÇÃO, E ESCOAMENTO POR

MÊS

Data

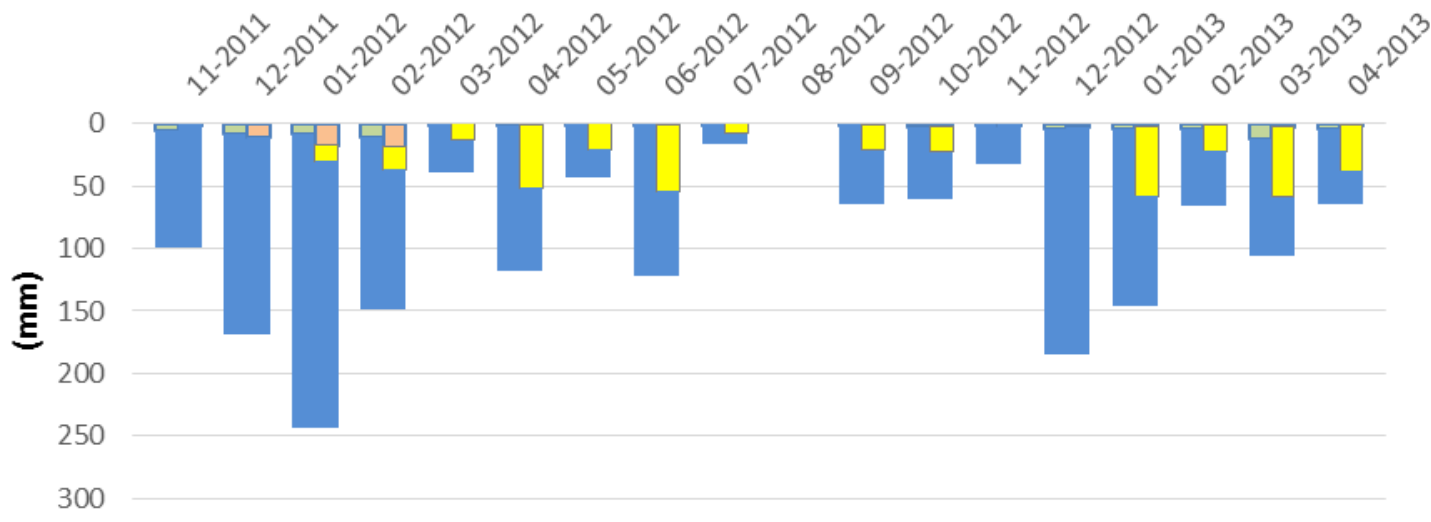

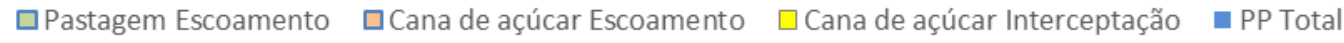

Figura 12 - Escoamento, interceptação e precipitação total por mês e cultura.

A redução do escoamento na cana-de-açúcar também foi identificada para o evento máximo individual de cada período. No primeiro ano, onde o solo não estava coberto com palha, registrou-se o maior volume de escoamento absoluto (12,5 mm em 23 de fevereiro 2012) e a maior taxa percentual de escoamento, relativa à chuva que a gerou (37\% de 16,6 mm em 22 de janeiro de 2012). No segundo ano, com a palha sobre o solo, o escoamento absoluto e a taxa percentual reduziram para 3,1 $\mathrm{mm}$ e $11,3 \%$ de $27,4 \mathrm{~mm}$ em evento do 12 de março de 2013. No mesmo evento, a pastagem registrou o maior volume de escoamento durante todo o estudo $(10,3 \mathrm{~mm})$, representando $37 \%$ da precipitação e um terço do escoamento total medido no segundo período. Esta situação aconteceu pela alta intensidade do evento (10 mm em 10min), após dois dias consecutivos de chuvas (precipitação anterior de $30 \mathrm{~mm}$ ).

Com estes resultados, pode-se afirmar que a substituição de pastagem por cana-de-açúcar aumentou o escoamento 15,6 mm durante o primeiro ano. Por outro lado, o uso das barreiras de palha durante o segundo ano reduziu o escoamento em 18,6 mm, em comparação com a pastagem.

Ao analisar os dados com o teste estatístico Mann-Whithney, foram encontradas diferenças significativas entre os tratamentos apenas durante o 
primeiro ano de medições $(P=0,0103)$. O segundo ano não apresentou diferenças estatísticas $(P=0,6387)$, pois que cana-de-açúcar reduziu seu escoamento, e foram registrados altos valores de escoamento na pastagem, os quais aumentaram sua variabilidade. Adicionalmente, as diferenças anuais dentro do mesmo tratamento também foram testadas, confirmando-se assim a redução do escoamento na cana-de-açúcar durante o segundo ano, através da significativa diferença estatística do primeiro ano $(P=0,046)$. Na pastagem, diferenças não foram encontradas.

Esta redução do escoamento na cana-de-açúcar durante o segundo ano deve-se principalmente à palha (resíduo da colheita sem queima) deixada em cordões em íntimo contato com o solo a cada três entre-sulcos. Esta barreira diminuiu a distância que o escoamento pode percorrer livremente, e reduz seu volume e velocidade, e ainda favoreceu sua infiltração. Outros estudos identificaram a diminuição do escoamento por efeito da palha na cultura de cana-de-açúcar. Em Pradópolis-SP, em parcelas de 1,0×0,5 $\mathrm{m}^{2}$ sob chuva simulada que mantiveram no mínimo $50 \%$ de área com palha nos entre-sulcos houve redução de $50 \%$ no escoamento quando comparado ao solo exposto (SILVA et al., 2012). MARTINS FILHO et al. (2009), obtiveram os mesmos resultados em parcelas de $11,0 \times 3,5 \mathrm{~m}^{2}$ sob chuva simulada em Catanduva-SP.

BEZERRA; CANTALICE (2006), em Carpina-PE, avaliaram separadamente o efeito da palha e do dossel de cana-de-açúcar na produção de escoamento em parcelas sob chuva simulada, comparando os resultados com o controle de solo exposto. Os autores encontraram que a maior proteção é conferida pelo dossel, já que a palha pode ter favorecido o escoamento por cima dela como um efeito impermeabilizante da superfície do solo, diminuindo a infiltração. Esses resultados não concordam com o encontrado no presente estudo, uma vez que o efeito da palha diminuiu muito mais o escoamento quando comparado com a presença apenas do dossel. Esta diferença pode ser atribuído ao tamanho das parcelas utilizadas por eles $\left(3 \times 1 \mathrm{~m}^{2}\right)$, onde o dossel escoou água para fora das parcelas como um guarda-chuvas, gerando um importante efeito borda que distorceu seus resultados.

Todos estes trabalhos anteriores discutem seus resultados concluindo que com o aumento na rugosidade que a palha produz na superfície do solo, 
confere-se resistência ao escoamento e incrementa-se a infiltração. A palha também tem um efeito protetor do solo ao reduzir sua desagregação e seu selamento superficial por impacto direto da gota de chuva.

\subsection{Erosão de solos}

Os resultados médios da erosão são apresentados nas Figuras 13 e 14 (dados individuais apresentam-se no Anexo 6), diferenciando as partículas que foram retidas no coletor das parcelas (principalmente areias), e as que ficam sedimentadas nas caixas d'água após seu transporte por suspensão (argilas e silte).

Os resultados de erosão seguem a mesma tendência do escoamento. Nas parcelas com pastagem, ocorre menos erosão que na cana-de-açúcar, com exceção dos dois primeiros eventos na pastagem que apresentaram valores maiores devido à perturbação do solo que foi produzida durante a construção das parcelas. Após estabilização das condições, a produção de sedimentos diminuiu e manteve-se entre 0 e 0,002 Mg.ha ${ }^{-1}$.evento- ${ }^{-1}$, distribuída em partes iguais entre sedimentos no coletor e nas caixas d'água durante todo período de monitoramento.

Durante o primeiro ano, o processo de erosão na cana-de-açúcar pode ser analisado em três fases distintas. Em uma primeira fase (desde o plantio até janeiro de 2012), as precipitações só produziram erosão de partículas até o coletor, com exceção no mês de dezembro de 2011 em um evento combinado de 82 e $20 \mathrm{~mm}$. Nessa fase, o solo encontrava-se descoberto e desagregado (após o gradeamento e plantio), situação favorável para a erosão até o desenvolvimento da cultura. Este período apresentou os maiores valores de erosão com pouco escoamento, retido nos sulcos da cana-de-açúcar (Figura 15). Esta situação demonstrou que os sedimentos colhidos são gerados próximo aos coletores por saltitamento (TOY; FOSTER; RENARD, 2002; MORGAN, 2009). 
EROSÃO POR EVENTO

0,40

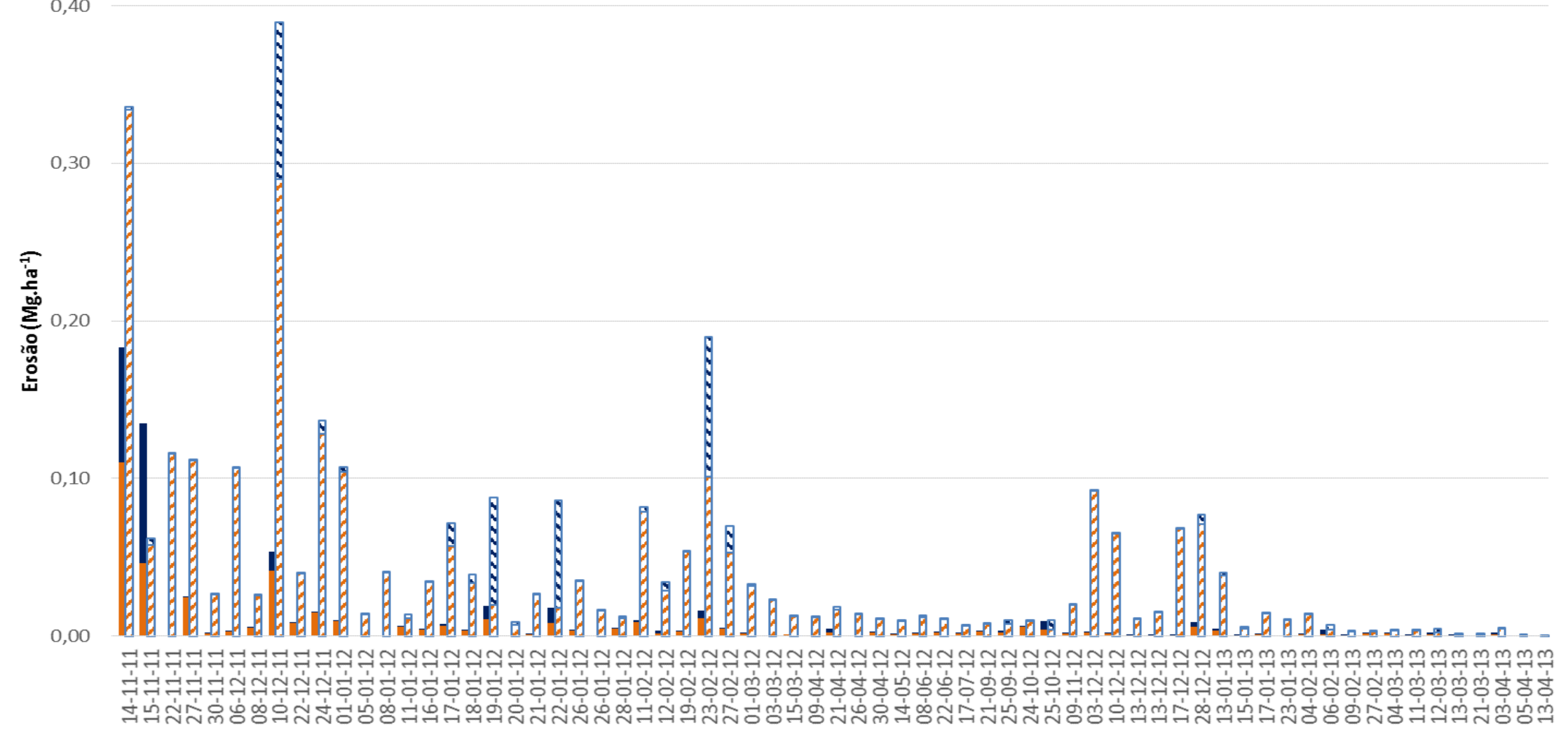
Data

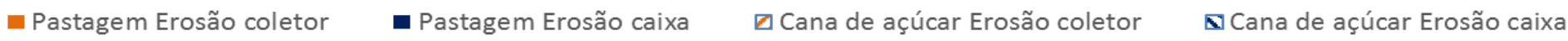

Figura 13 - Erosão por evento e cultura. Indica-se o lugar onde foram coletados os sedimentos (coletor ou caixa d'água). 


\section{EROSÃO POR MÊS}

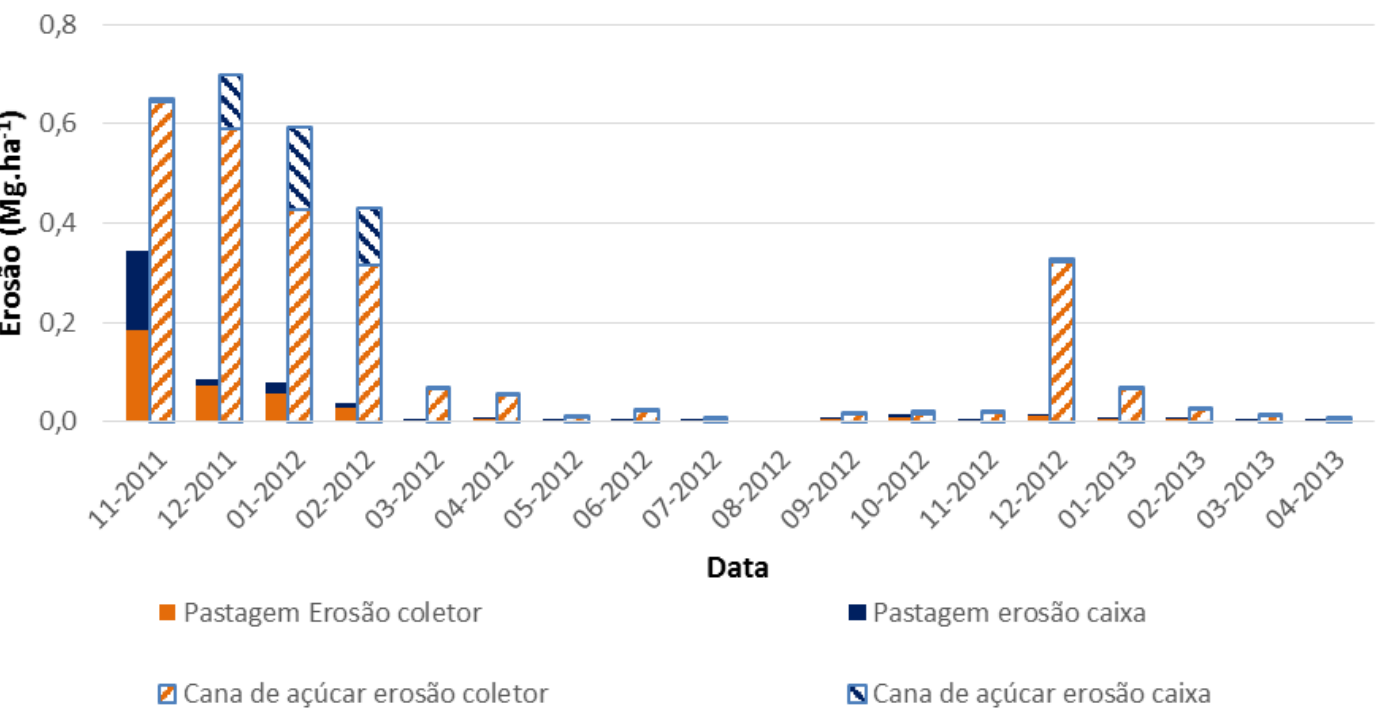

Figura 15 - Escoamento, interceptação, precipitação total e erosão por mês e cultura. Indica-se o lugar onde foram coletados (coletor ou caixa d'água).

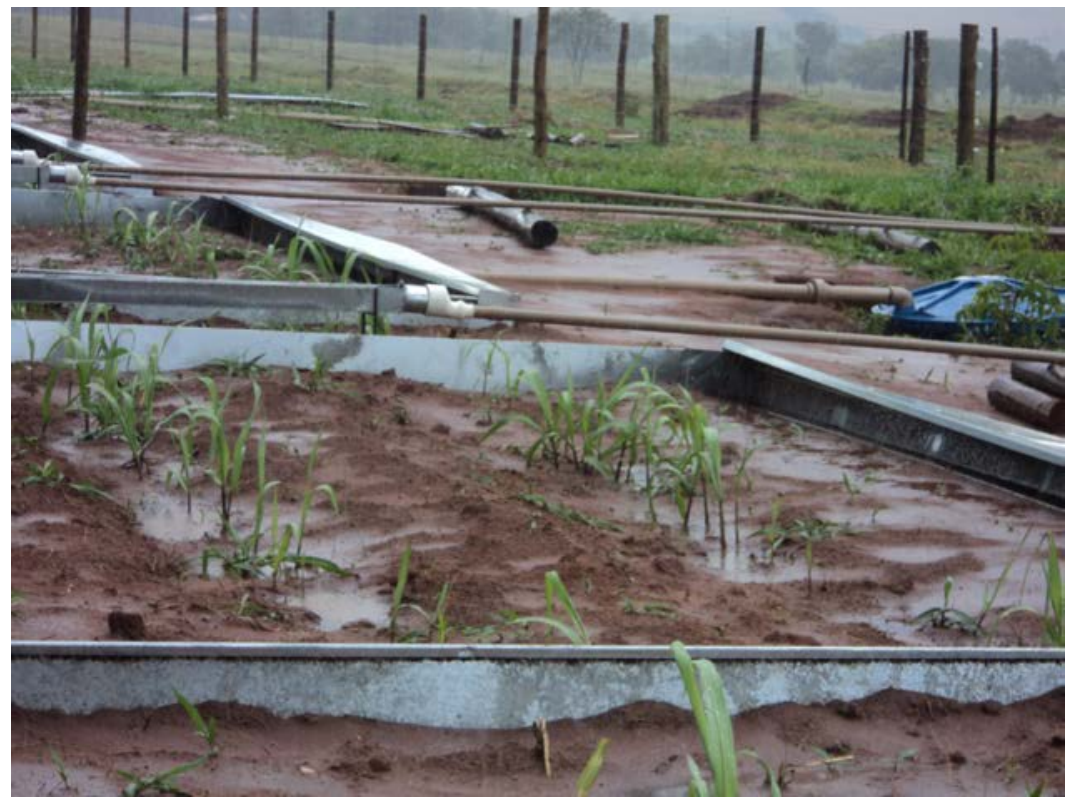

Figura 14 - Escoamento superficial retido nos sulcos de cana-de-açúcar num evento de chuva. 
Em uma segunda fase, correspondente ao desenvolvimento da cobertura da cana-de-açúcar (a partir de janeiro até março de 2012), a produção de sedimentos até o coletor diminuiu e iniciou a erosão de sedimentos (principalmente em suspensão) até as caixas d'água. Isto deve-se ao aumento do escoamento pelo selamento superficial do solo, observado em campo e descrito na literatura (BEZERRA; CANTALICE, 2006; BRANDÃO et al., 2007; TOMASINI et al., 2010; GARBIATE et al., 2011), pela diminuição da rugosidade da superfície do solo (BRAMORSKI et al., 2012) e pelo assoreamento e ruptura dos sulcos em curva de nível onde foi plantada a cana (Figura 16). Os sedimentos que atingem as caixas d'água são transportados ao longo das parcelas pelo escoamento, especialmente em eventos de alta pluviometria, de alta intensidade ou de alta frequência de chuvas, quando o escoamento percorre todo o comprimento das parcelas.

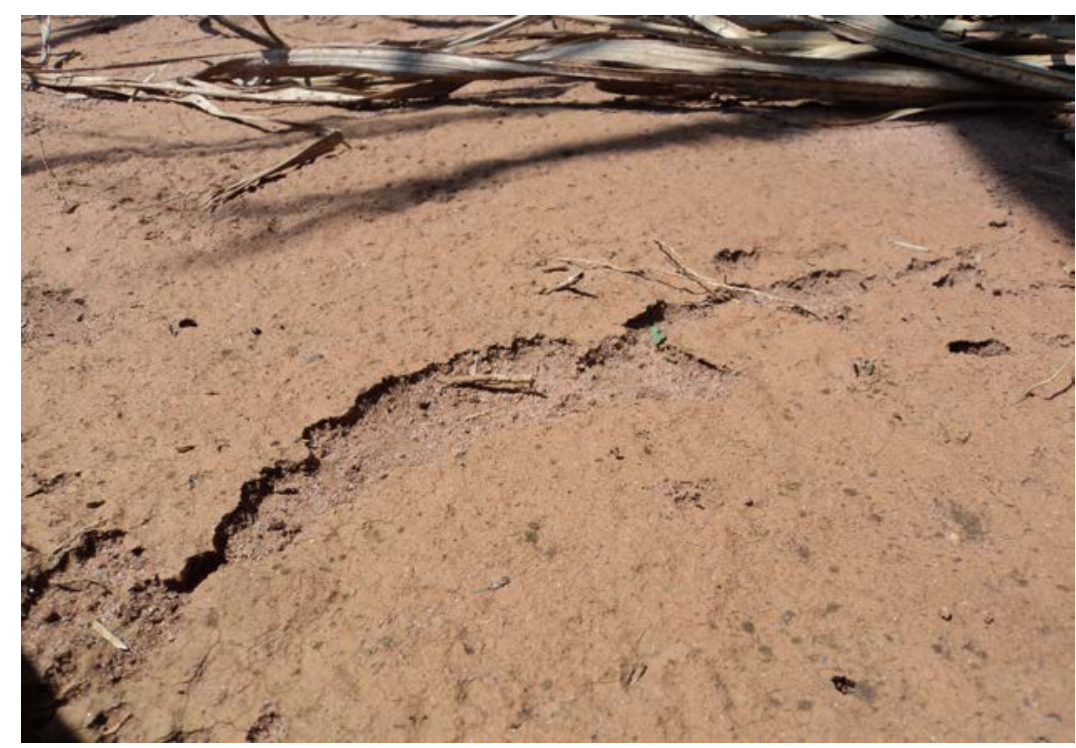

Figura 16 - Superfície do solo nos entre-sulcos sob cana-de-açúcar, apresentando um selamento superficial e pequenas ravinas ao longo das parcelas.

Nesta fase existem eventos com pouco escoamento e com poucos sedimentos nas caixas d'água. Neste caso, a erosão e o escoamento estariam sendo produzidos na área junto ao coletor, situação confirmada pelo fato da primeira parcela de cana-de-açúcar sempre ter um pouco a mais de escoamento e de erosão que as outras duas (Anexo 6), sendo que a única 
diferença era o distanciamento entre o coletor e a primeira fileira de plantas (80 cm versus $60 \mathrm{~cm})$, resultante na construção das parcelas.

Uma terceira fase é identificada a partir de março de 2012, quando ocorre a redução da frequência das precipitações e a redução da erosão, uma vez que a cobertura da cana-planta está desenvolvida. A planta protege o solo do impacto da chuva e gera barreiras de folhas que freiam o escoamento na superfície do solo. Nesta fase, a taxa de erosão foi em média $0,01 \mathrm{Mg} \mathrm{ha}^{-1}$ por evento, valor que se manteve até a colheita.

Após a primeira colheita da cana-planta, a cultura denomina-se cana-soca e o rebroto nasce das raízes. O crescimento da nova estrutura aérea é mais rápida que para a cana-planta, e o solo gradeado permanece exposto por menos tempo ao efeito erosivo das chuvas. A palha que resta da colheita anterior é disposta sobre o solo a cada três entre-sulcos, reduzindo a superfície de solo exposto e freando o escoamento (Figura 17). Isto se traduz em uma menor erosão carreada pelo escoamento até as caixas d'água, e uma breve temporada de erosão retida no coletor, comparada com cana-planta. Assim, os resultados de erosão obtidos na cana-soca $\left(0,47\right.$ t.ha $\left.^{-1}\right)$ foram menores do que na cana-planta $(2,58$ t.ha-1.ano-1).

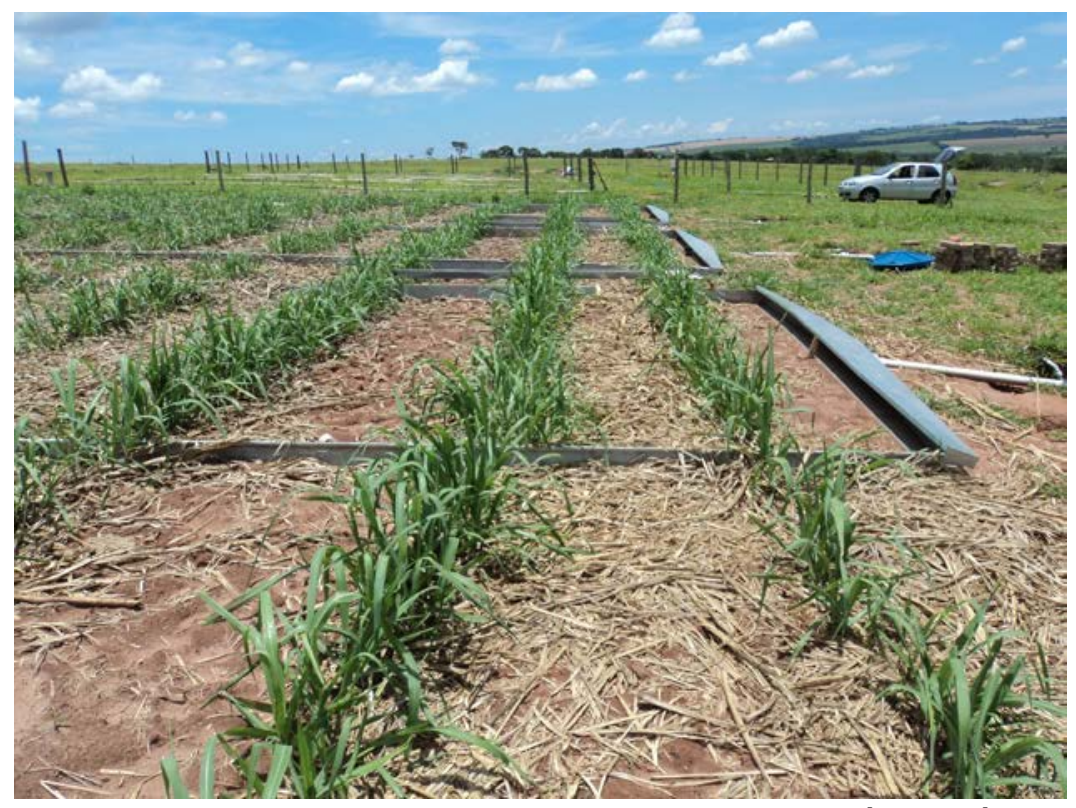

Figura 17 - Parcelas de cana-soca um mês apôs a colheita, com os entre-sulcos gradeados e cobertura de palha a cada três entre-sulcos. 
Durante o primeiro ano, a pastagem teve uma perda de solo de 0,58 Mg.ha-1.ano-1, (mas 0,32 Mg.ha-1 podem ser descontados deste valor, devido à perturbação do solo durante a instalação do experimento). Nos primeiros seis meses do segundo ano, o valor diminui até 0,04 Mg.ha-1. Já para a cana-de-

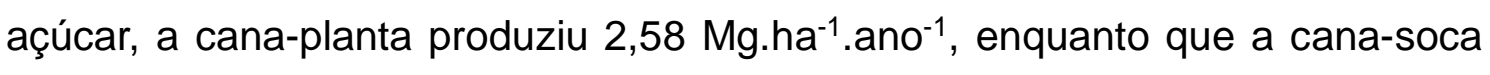
registrou 0,47 Mg.ha-1. Estes resultados indicam que a substituição de pastagem por cana-de-açúcar aumentou a produção de sedimentos durante a etapa de cana-planta em 2,32 Mg.ha-1, e depois na etapa cana-soca diminuiu em 0,43 Mg.ha-1 com o uso das barreiras de palha a cada três entre-sulcos.

Ao analisar os dados com o teste estatístico Mann-Whithney, encontram-se diferenças significativas na produção de sedimentos entre os tratamentos durante o primeiro $(P=0,0000)$ e o segundo ano de medições $(P=0,0008)$. Também foram testadas as diferenças anuais para cada tratamento. Assim, confirma-se que a redução da erosão na cana-de-açúcar durante o segundo ano foi devido ao uso da palha, sendo estatisticamente diferente do primeiro ano $(P=0,005)$. Na pastagem, diferenças também foram encontradas $(P=0,0198)$.

Os resultados obtidos nesta pesquisa concordam com o descrito na literatura. SILVA et al. (2012) concluíram que, em seu experimento sob chuva simulada, o aumento da cobertura do solo com palha reduz exponencialmente a perda de solo. Assim, com 50\% de palha na superfície dos entre-sulcos, a erosão reduz em $85 \%$ comparado com solo exposto. Os autores também detectaram que acima de $50 \%$ de cobertura, a erosão é mínima mas nunca igual a zero, e sem diferença estatística entre 75 ou 100\% de cobertura. Resultados similares foram descritos por SOUSA; MARTINS FILHO; MATIAS (2012), os quais avaliaram três declividades diferentes (2,5\%,5\% e 7\%) e cinco níveis de cobertura de palha no solo (0, 25, 50, 75 e 100\%) e concluíram que, independentemente da declividade, a erosão é sempre reduzida nos níveis de cobertura acima de 50\%. Finalmente, BEZERRA; CANTALICE (2006) avaliaram o efeito protetor da palha, do dossel e sua ação combinada e concluíram que o efeito protetor da palha no solo é maior do que o do dossel, quando avaliados individualmente. Quando combinados, há uma redução de 99\% na erosão, quando comparado com solo exposto. 


\subsection{Interceptação}

Nas Figuras 11 e 12 se observa que a interceptação da chuva pelo dossel começa no mês de janeiro, tanto no primeiro quanto no segundo ano. A interceptação durante o primeiro ano é de $217 \mathrm{~mm}$, equivalente a $19 \%$ da precipitação do período. Durante o segundo ano, a interceptação é de $169 \mathrm{~mm}$, e corresponde a $28 \%$ da precipitação nos primeiros seis meses da cana-soca. Ao analisar os resultados com o teste estatístico de Mann-Whitney verifica-se que não existe diferença interanual significativa $(P=0,2295)$. A maior interceptação aconteceu no evento de 13 de janeiro de 2013, interceptando 40 $\mathrm{mm}$ da precipitação que registrou $93,6 \mathrm{~mm}$ (42\% do total). A interceptação percentual de cada evento é apresentado na Figura 18.

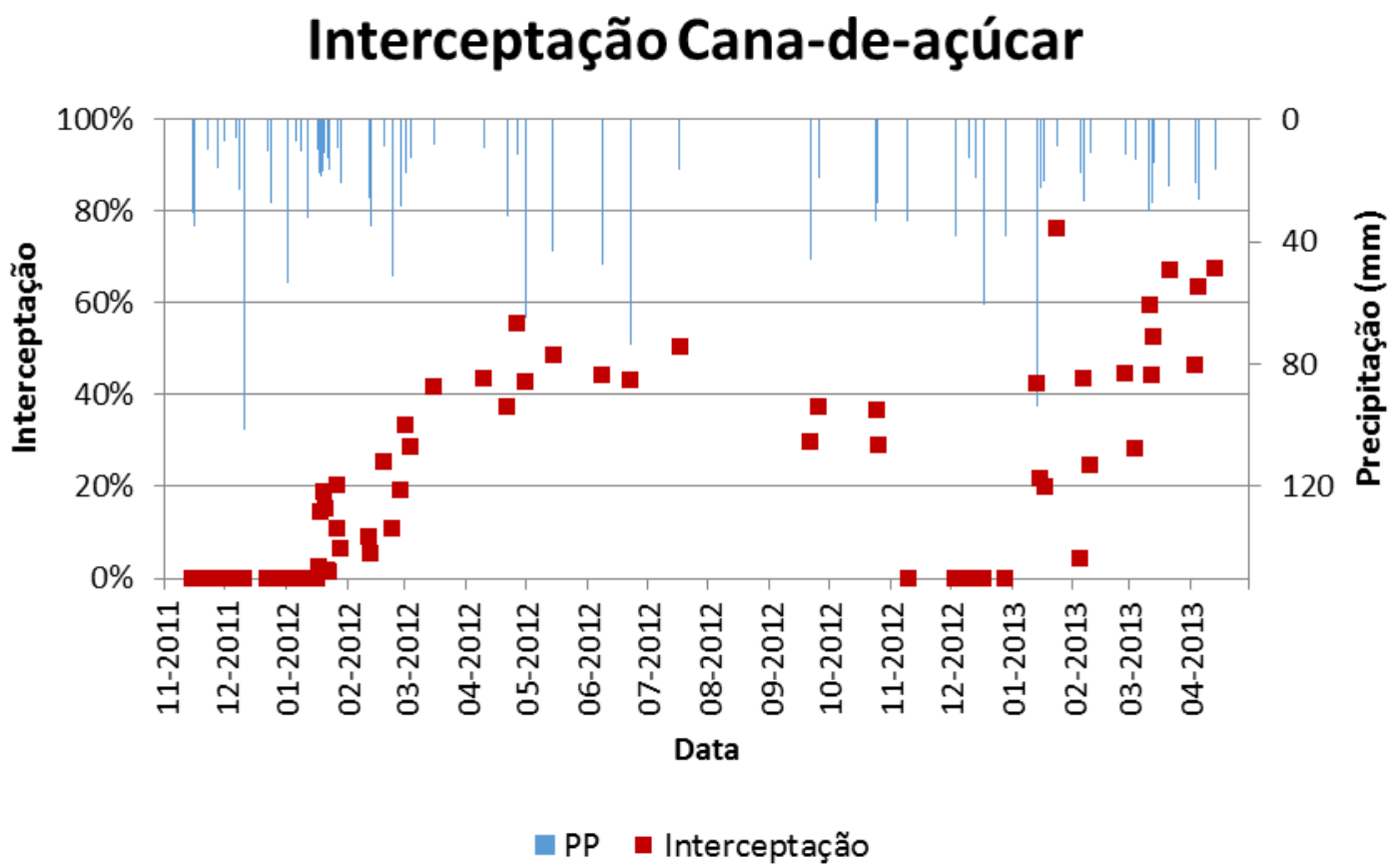

Figura 18 - Variação da interceptação ao longo do tempo, expressa em porcentagem da precipitação de cada evento.

Na Figura 18 é claramente visível o aumento gradual da interceptação a medida que a cobertura da cana-de-açúcar vai se desenvolvendo, a qual estabilizou a partir de março de 2012. No primeiro ano, os valores estabilizaram entre 40 e 50\% de interceptação. No segundo ano, a interceptação atingiu mais 
rapidamente esta porcentagem, desde janeiro (mesmo que irregularmente), mas da mesma forma, a interceptação estabilizou-se também a partir de março de 2013. Isto pode ser explicado pelo rápido crescimento da cana-soca comparada com a cana-planta e pela menor ocorrência de eventos de alta pluviometria durante o segundo ano. A menor pluviometria também explica as maiores porcentagens de interceptação no verão de 2013, em que a fração da precipitação que foi retida no dossel foi proporcionalmente alta quando comparada com o ano anterior.

As primeiras chuvas depois da temporada seca (setembro-outubro 2012) destacam-se pela interceptação (próximas a 30\%) abaixo do valor de 40\% discutido anteriormente. Ao analisar os dados pluviométricos, descarta-se que esta diminuição tenha sido provocada por diferenças na lâmina precipitada, na intensidade ou na frequência das chuvas, podendo ser explicada unicamente por modificações morfológicas do dossel, como uma possível senescência ou queda das folhas. Isto é confirmado no artigo de interceptação na cana-deaçúcar de TEIXEIRA et al. (2012), onde alguns estudos das alterações morfológicas que as plantas sofrem sob condições de deficiência hídrica foram citados, tais como enrolamento da folha, alteração do ângulo da folha ou redução da área folear.

Os resultados obtidos neste estudo concordam com 0 descrito por CASTILHO (2000), que estudou a interceptação em cana-soca, entre fevereiro e dezembro de 1999 em Campinas-SP, usando o mesmo sistema de calhas. No estudo foi registrada uma interceptação média de $39,5 \%$ do total de precipitações, diferenciando-se um pouco da presente pesquisa, na qual foram contabilizadas apenas as precipitações que geraram escoamento. Um estudo mais detalhado em cana-de-açúcar sob irrigação foi desenvolvido por TEIXEIRA et al. (2012) em Jaíba-MG entre junho 2008 e junho 2009. Nesse estudo foi medida a interceptação usando caixas coletoras quadradas de $1 \mathrm{~m}^{2}$ no entre-sulco, e também foi medida a água escoada pelo colmo com um cone coletor colado na base da cana. Os resultados indicaram que a interceptação variou entre 14 e 32\%, diferenciando-se dos resultados obtidos por CASTILHO (2000) e este estudo, devido à metodologia de coleta da interceptação, localizada no centro do entre-sulco, sendo o espaço mais aberto da cultura e 
onde se registra menor interceptação do dossel. Os resultados do escoamento pelo colmo indicaram que este é responsável por 20 a 25\% da lâmina de água que atinge o solo. Ao integrar estes valores com os resultados obtidos no presente estudo, pode-se inferir que metade da lâmina interceptada no dossel (>40\% da precipitação total) finalmente desceria até o solo por uma via que não foi considerada nesta pesquisa, e que deve ser medida em pesquisas posteriores.

Outro fator a ser considerado nos resultados de interceptação deste estudo é que as primeiras linhas de cana (onde foram alocadas as calhas de interceptação) tiveram o maior crescimento de todo o plantio, muito provavelmente devido a uma variação nas concentrações de nutrientes no solo. Isto pode ser explicado pela presença de uma curva de nível de 0,5 $\mathrm{m}$ de altura onde essas linhas estavam localizadas, a qual teve que ser nivelada para 0 estabelecimento do plantio e para a construção das parcelas. Ao longo dos anos, o escoamento que foi retido nessas curvas teria transportado e concentrado nutrientes no local, o que explicaria o rápido crescimento das três primeiras linhas de cana e da pastagem (mesmo sem adubação). Esta situação pode ter influenciado em uma certa distorção no tempo necessário para atingir o valor de $40 \%$, sendo mais acelerada do que aconteceria em um plantio de crescimento homogêneo.

\subsection{Umidade do solo}

A porcentagem de umidade do solo para cada cultura a 30, 60 e $90 \mathrm{~cm}$ de profundidade é apresentada na Figura 19. Nos dois tratamentos, a umidade é indiretamente proporcional à profundidade. Em pastagem, o intervalo varia desde 6,5 a 21,9\%, enquanto em cana-de-açúcar este intervalo se amplia de 6,2 a 25,6\%. Ao comparar a umidade nas distintas profundidades entre os tratamentos, pode-se reconhecer que não há muita diferença nos valores mínimos, mas as grandes variações são registradas nos valores máximos. Assim, os picos de valores na cana-de-açúcar apresentam 3,8; 5,7 e 6,8\% mais umidade que pastagem a 30, 60 e $90 \mathrm{~cm}$, respectivamente. 


\section{A. Umidade no perfil do solo: Pastagem}

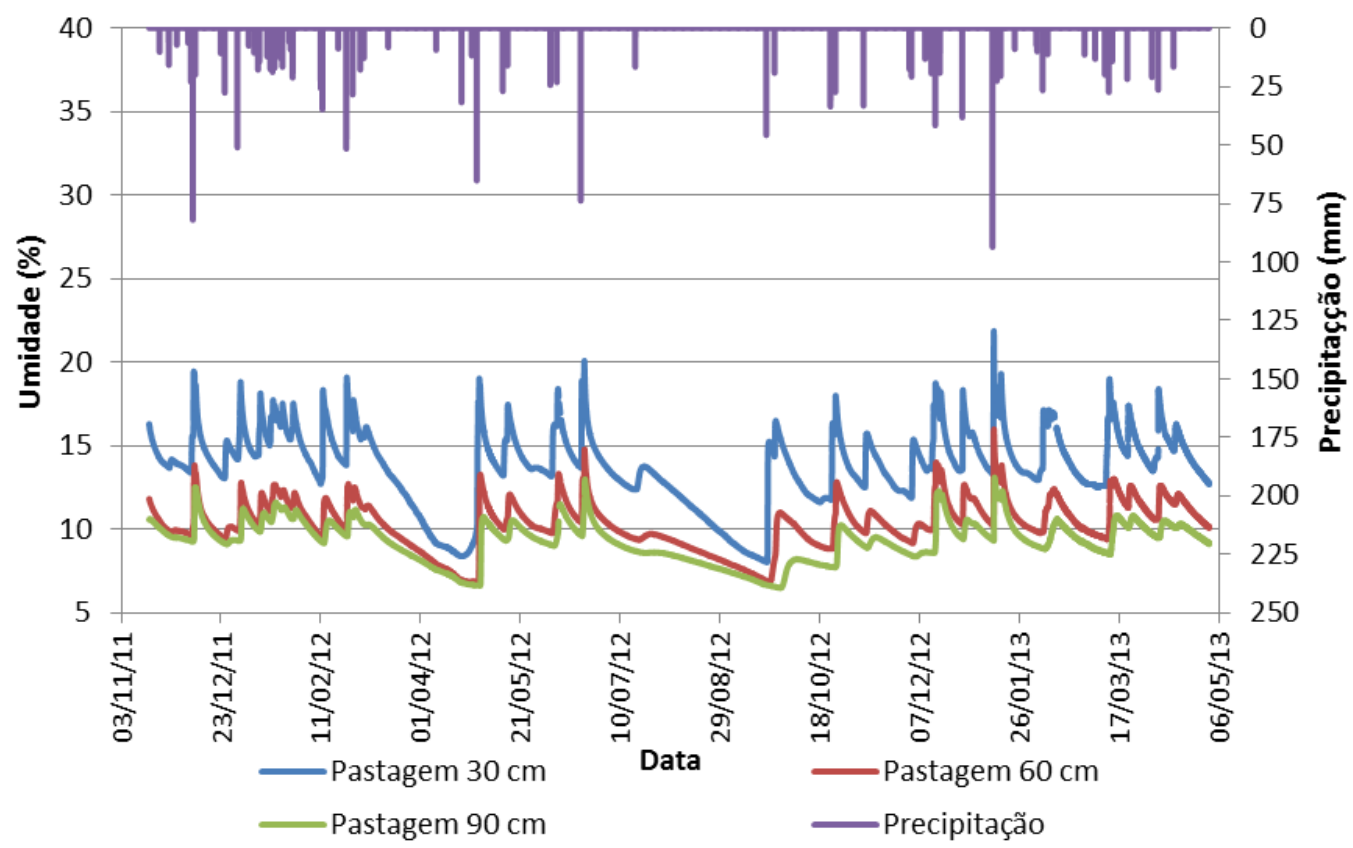

B. Umidade no perfil do solo: Cana-deaçúcar

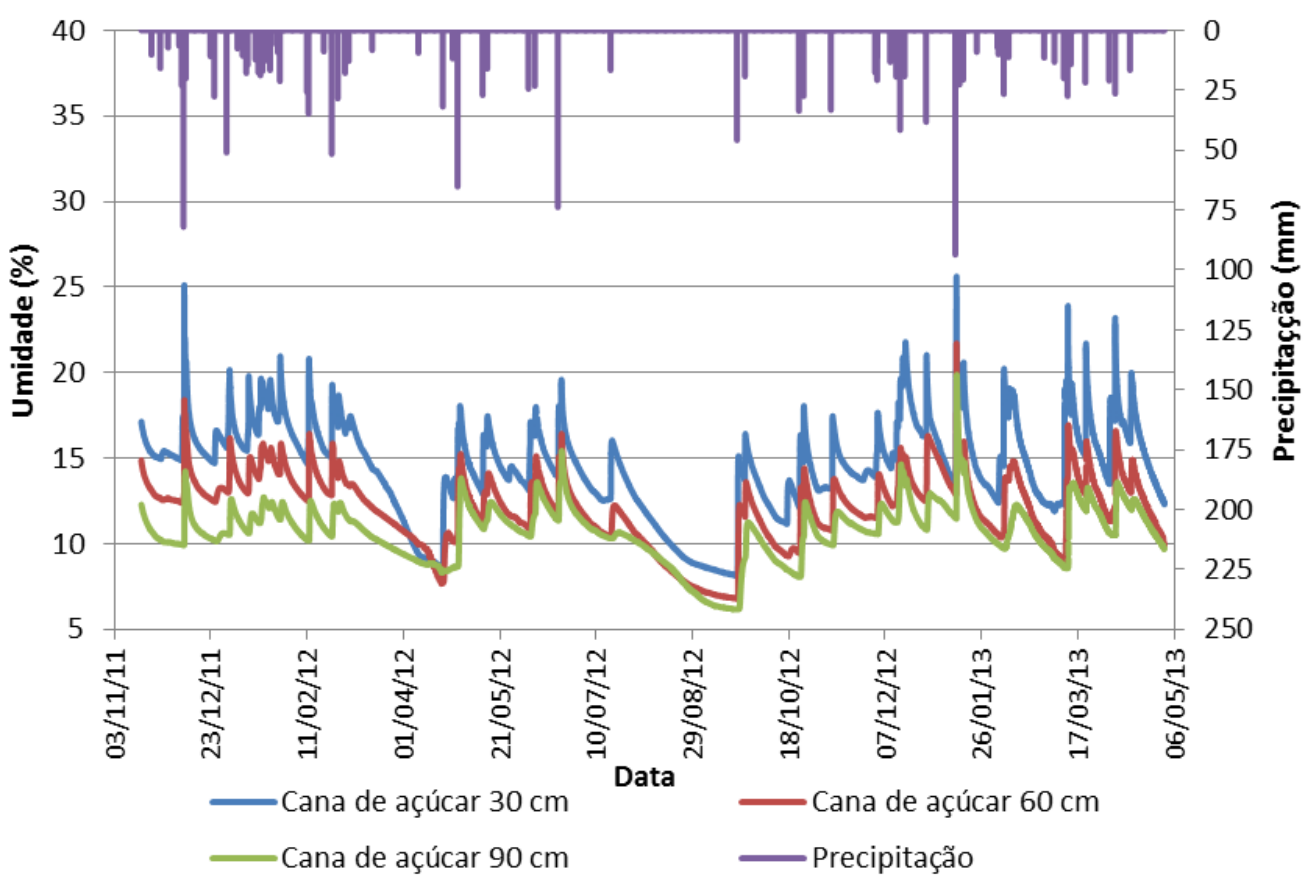

Figura 19 - Umidade do solo em pastagem (A) e cana-de-açúcar (B) expresso em porcentagem, às profundidades de 30,60 e $90 \mathrm{~cm}$. 
A maior umidade de solo em cana-de-açúcar (Figuras 19 e 20) é explicada pelo efeito de gradeamento do solo, o que aumentou a porosidade e, portanto, a capacidade de infiltrar, conter e reter uma lâmina maior de água no perfil. Este fato foi comprovado com testes de densidade do solo das profundidades estudadas (Anexo 7). O solo sob cana-de-açúcar tem menor densidade entre 30 e $60 \mathrm{~cm}$ quando comparado com o solo em pastagem (1,56 e 1,53 versus 1,66 e 1,60, respectivamente), o que reflete a maior porosidade. Em $90 \mathrm{~cm}$ de profundidade, as densidades são iguais entre os tratamentos $(1,52)$, já que em cana-de-açúcar foi gradeado até os $60 \mathrm{~cm}$. Esta mesma densidade (e, portanto, porosidade) aos $90 \mathrm{~cm}$ de profundidade não esclarece a maior umidade máxima medida sob cana-de-açúcar. A diferença pode ser consequência da maior lâmina de água que drena desde as camadas superficiais nos eventos de precipitações.

Ao analisar a porcentagem de umidade do solo em pastagem a diferentes profundidades, em geral, pode-se observar que as linhas seguem a tendência de se manterem paralelas, com a umidade aos $60 \mathrm{~cm}$ mais próxima daquela medida aos $90 \mathrm{~cm}$. Este padrão não é repetido nos primeiros meses em canade-açúcar, pois a umidade aos $60 \mathrm{~cm}$ mantém-se numa porcentagem intermediária entre as leituras de 30 e $90 \mathrm{~cm}$. Entre os meses de março e abril de 2012 ocorreu uma diminuição das precipitações, o que se reflete na diminuição da umidade do solo, mas que é diferenciada em profundidade na cana-de-açúcar. No início de abril de 2012 a umidade dos $30 \mathrm{~cm}$ fica abaixo da medida em $60 \mathrm{~cm}$, e posteriormente, a umidade a $60 \mathrm{~cm}$ fica abaixo da medida em $90 \mathrm{~cm}$, fato que não volta a se repetir no estudo. Isto deve-se a uma adaptação da cana-de-açúcar frente ao primeiro período de seca. No início, as raízes cresceram superficialmente devido à disponibilidade de água nos primeiros centímetros do perfil do solo, no período de chuvas frequentes. Com a seca, as raízes esgotaram a água disponível superficialmente e cresceram, explorando e consumindo a água escalonadamente em profundidade. Após esta primeira seca, o padrão em cana-de-açúcar segue as mesmas características descritas para pastagem.

Já foi discutido o efeito redutor do escoamento que tem o uso das barreiras de palha a cada três entre-sulcos na cultura de cana-de-açúcar durante o 
segundo ano, o que aumenta a infiltração de água no solo. Este efeito é refletido por um aumento nos picos de umidade acima de $20 \%$ a $30 \mathrm{~cm}$ de profundidade, medida nos eventos de precipitação.

Com as porcentagens de umidade de solo a diferentes profundidades e por cultura, foi calculada a lâmina de água presente no perfil até um metro de profundidade. Os resultados são mostrados na Figura 20, e como já foi discutido com os valores a diferentes profundidades, o solo sob cana-de-açúcar tem maior umidade em comparação com a pastagem. Pode-se observar que a umidade no solo sob cana-de-açúcar tem maior sensibilidade aos eventos de precipitação, com a presença de picos, enquanto sob pastagem só se registra uma leve variação da umidade (24 de abril de 2012, depois da primeira seca, 22 de maio, 17 de outubro e 26 de novembro de 2012). Isto deve-se à maior capacidade de infiltração apresentados pelo solo sob cana-de-açúcar, uma vez que foi gradeado.

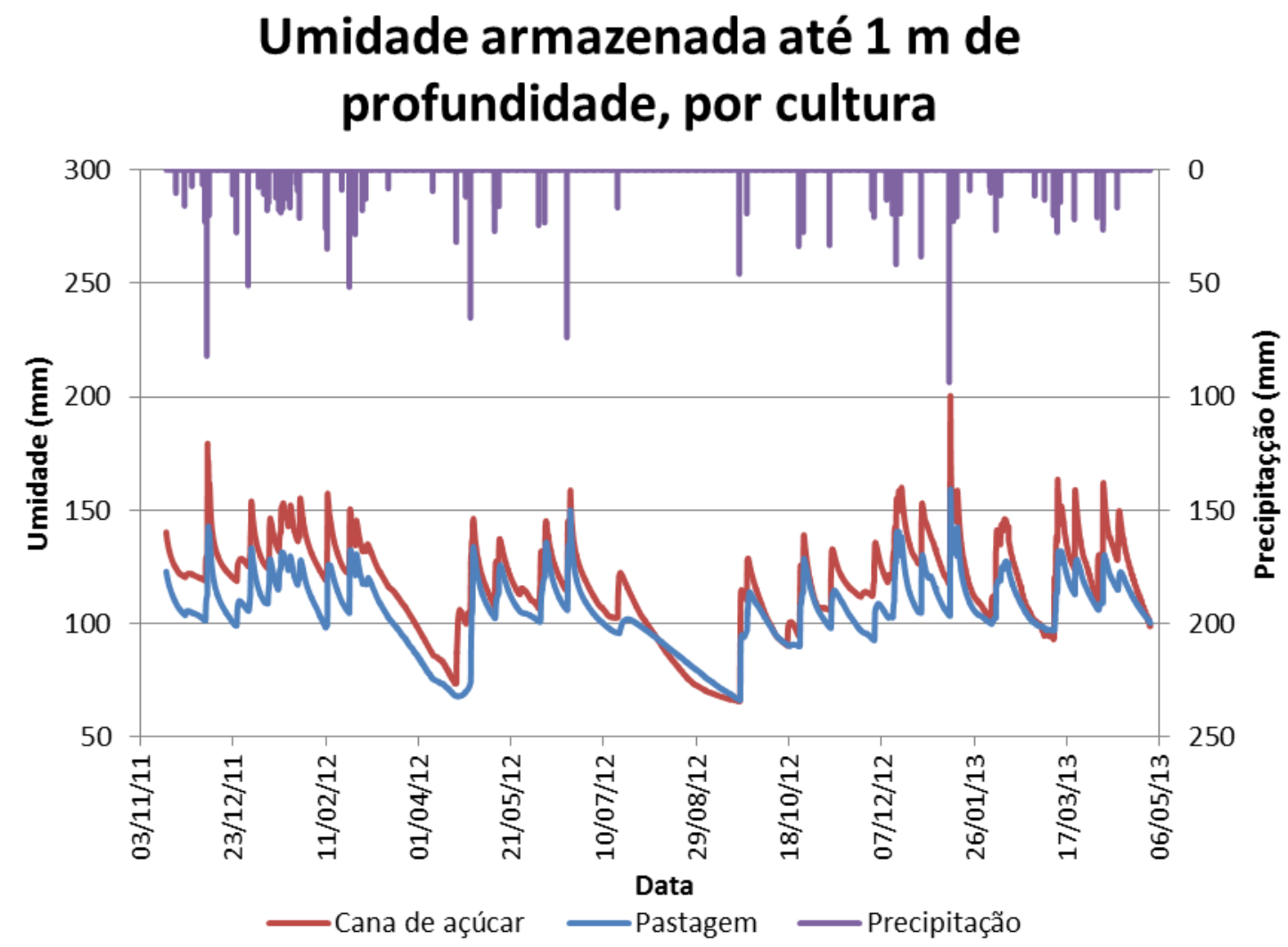

Figura 20 - Lâmina de umidade armazenada até $1 \mathrm{~m}$ de profundidade, para solo sob pastagem e cana-de-açúcar. 
No final de agosto de 2012, após o período de seca, observa-se uma diminuição da umidade do solo sob cana-de-açúcar maior que sob pastagem. Esta situação deve-se à maior extração de água do perfil pela evapotranspiração da cultura, o que será discutido posteriormente. Com os valores de umidade armazenada no primeiro metro de profundidade, foi calculada a variação diária de umidade, e os resultados são mostrados na Figura 21.

\section{A. Variação diária de umidade no solo: Pastagem}

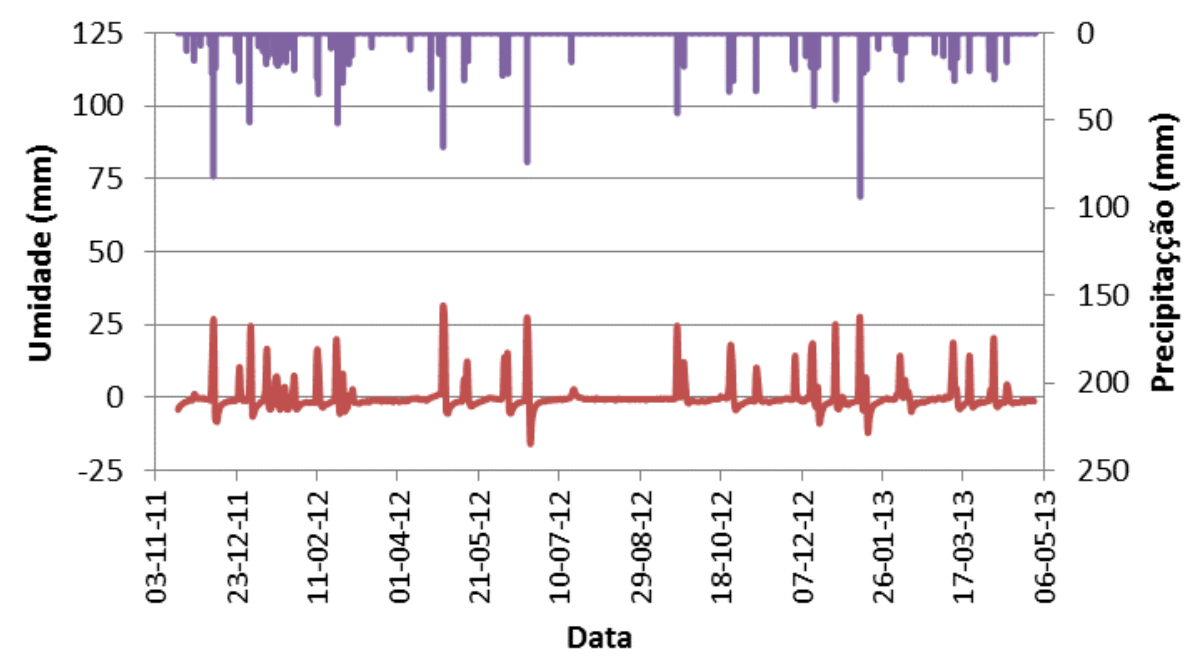

B. Variação diária de umidade no solo: Cana-de-açúcar

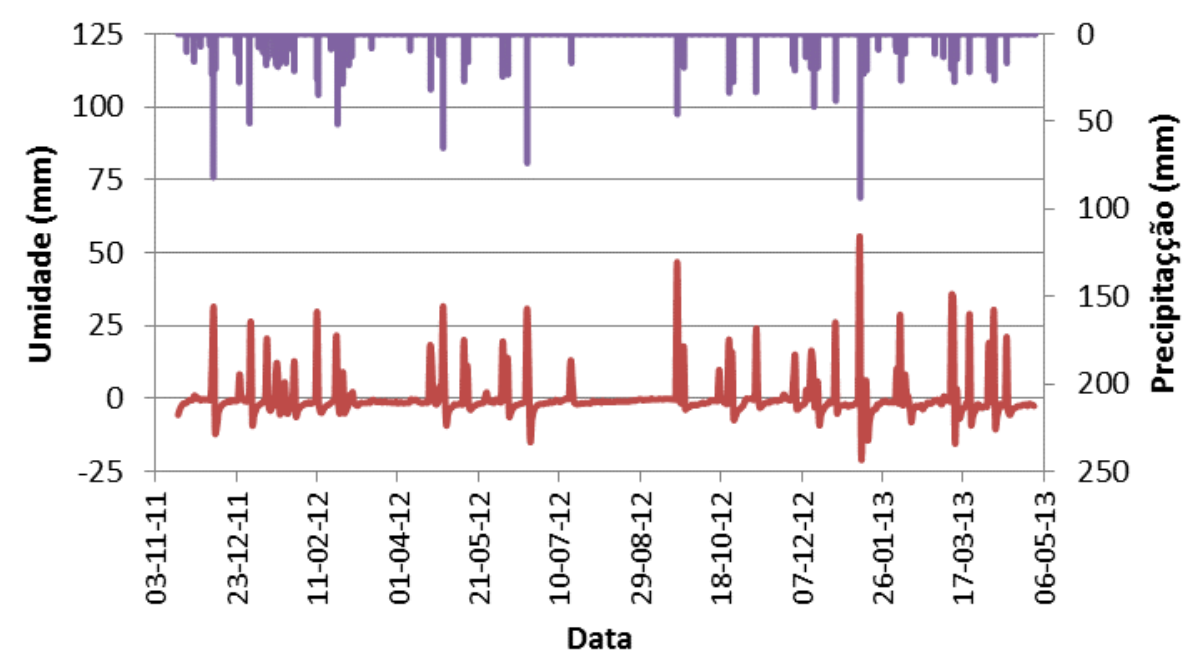

Figura 21 - Variação diária de umidade no primeiro metro do solo em pastagem (A) e cana-de-açúcar (B), expressos em mm. 
Estes resultados também refletem a maior variação de umidade sob canade-açúcar, especialmente durante o segundo ano. A maior perda de umidade no solo acontece depois dos eventos de precipitação, causado pela drenagem.

O sensor de umidade foi instalado junto à linha de cana-de-açúcar com o objetivo de medir a umidade disponível nas raízes da planta. Esta instalação permite, apenas, que as medições sejam feitas junto ao sulco do plantio, onde há acumulação de escoamento (superficial e dos colmos, segundo o discutido para interceptação), portanto apresenta maior infiltração de água em comparação com o entre-sulco. Este caso poderia produzir uma distorção nos resultados de umidade em cana-de-açúcar, uma vez que é uma medição pontual que não necessariamente representa a umidade do solo em todo o canavial.

Poucos estudos foram desenvolvidos para determinar as variações de umidade do solo em cana-de-açúcar e pastagem. PERES; SOUZA; LAVORENTI (2010), avaliaram durante um mês, na época da seca e sem plantas, o efeito da palha na umidade entre 10 e $30 \mathrm{~cm}$ de profundidade, em Latossolo vermelho, em Araras-SP. Para tanto, aumentaram a umidade do solo para valores próximos à capacidade de campo, com metade das parcelas cobertas com $100 \%$ de palha, e a outra metade deixada como solo exposto. Os resultados do artigo indicam que a umidade e o efeito da palha diminuem com o aumento na profundidade do solo, concordando com o observado na presente pesquisa. Os autores também concluíram que a presença de palha reduz à metade a perda de água nos primeiros $20 \mathrm{~cm}$ do solo e que as perdas de água do perfil ocorrem por evaporação (na condição sem palha) ou percolação profunda (condição com palha).

BRITO; LIBARDI; GHIBERTO (2009), avaliaram com tensiômetros a umidade no solo até $90 \mathrm{~cm}$ sob cana-de-açúcar, com e sem adubação nitrogenada, em Jaboticabal e Pirassununga-SP, entre setembro de 2005 e junho-julho de 2006. Os autores reconhecem a alta relação da umidade do solo com os eventos de precipitação, mas não encontrou-se diferença na água armazenada no solo entre os diferentes tratamentos. GHIBERTO et al. (2011), quantificaram a umidade do solo até $1 \mathrm{~m}$ em cana-de-açúcar sob três concentrações diferentes de adubo nitrogenado e enxofre. Foi utilizado o 
método gravimétrico, com coleta de amostras a cada 20 dias, entre outubro de 2006 e julho de 2007 em Jaboticabal-SP. Os autores não identificaram diferenças entre os tratamentos, com a umidade do solo variando entre 1,4 e $5,5 \%$ com alto desvio padrão. Este pequeno intervalo deve-se às descontínuas medições a cada 20 dias, não incluindo os valores máximos que ocorrem nos eventos de precipitação.

\subsection{Evapotranspiração}

Os valores de evapotranspiração para pastagem e cana-de-açúcar foram calculados segundo o método de Penman-Monteith, apresentam na Figura 22. No gráfico observa-se que a evapotranspiração potencial de referência (ETo) é maior que a evapotranspiração da cultura $(E T c)$ em pastagem $(K c=0,75)$. Após o plantio e a colheita, a evapotranspiração em cana-de-açúcar está abaixo dos níveis calculados para a pastagem, mas à medida que a cultura se desenvolve, esses valores atingem níveis maiores que a evapotranspiração de referência. Este comportamento deve-se aos coeficientes da cultura $(K c)$ de cada cobertura e estado de desenvolvimento.

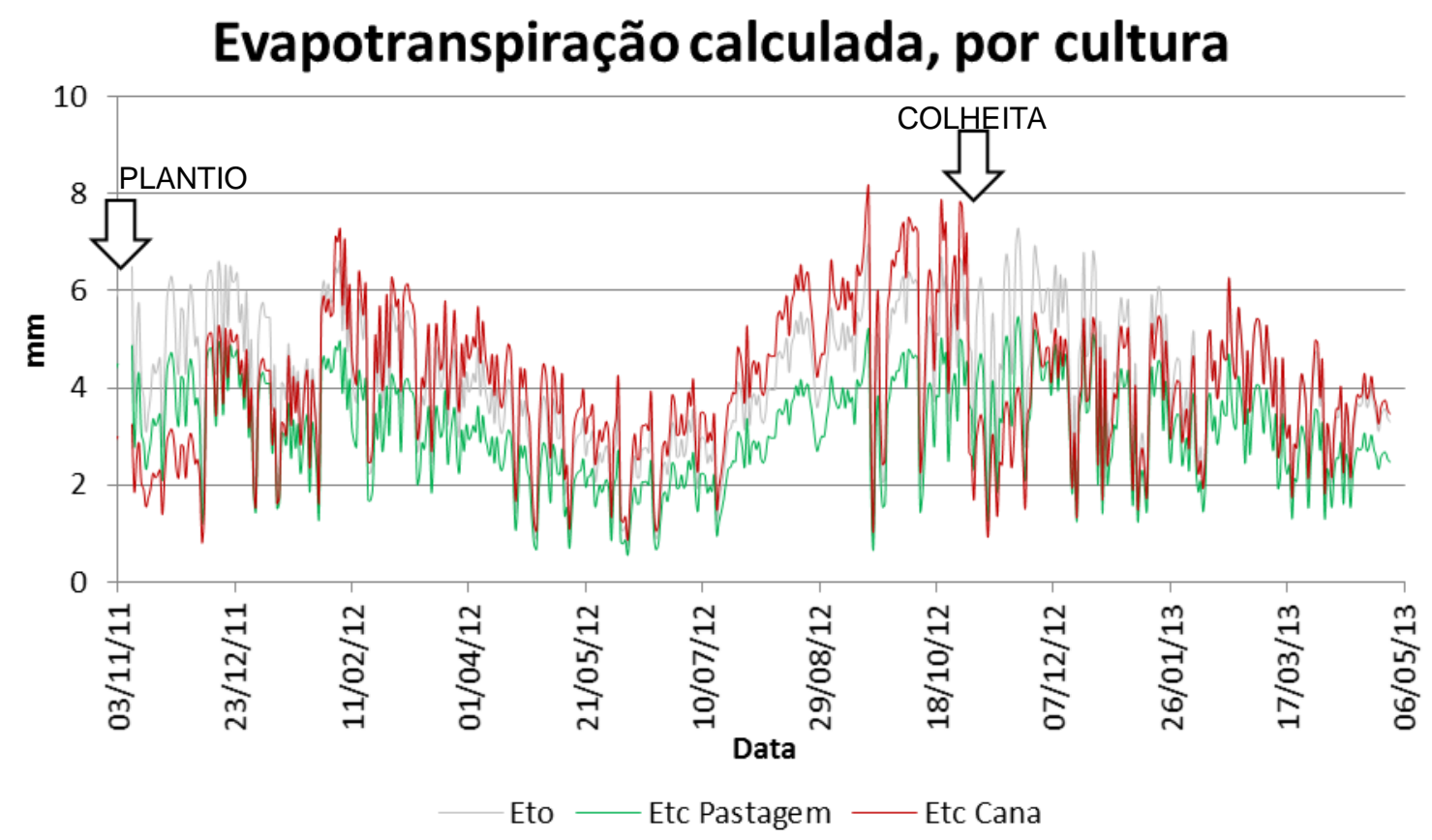

Figura 22 - Evapotranspiração potencial de referência (cinza), e evapotranspiração em pastagem (verde) e cana-de-açúcar (vermelho), calculados segundo o método Penman-Monteith. 
Os resultados da Figura 22 representam a evapotranspiração máxima potencial que a cultura pode ter em condições de oferta ilimitada de água, mas nas condições experimentais isto não aconteceu com a ocorrência de períodos de restrição hídrica. Por este motivo, os resultados de evapotranspiração foram ajustados, segundo a disponibilidade de água no solo medida com o sensor de umidade e discutida anteriormente. Assim estabeleceu-se a restrição de que a evapotranspiração diária de cada cultura não pode ser maior que a variação diária de umidade do solo medida. Em caso contrário, a evapotranspiração do dia é substituída pela variação de umidade no solo (Equações 3 e 4). Os resultados são apresentados na Figura 23.

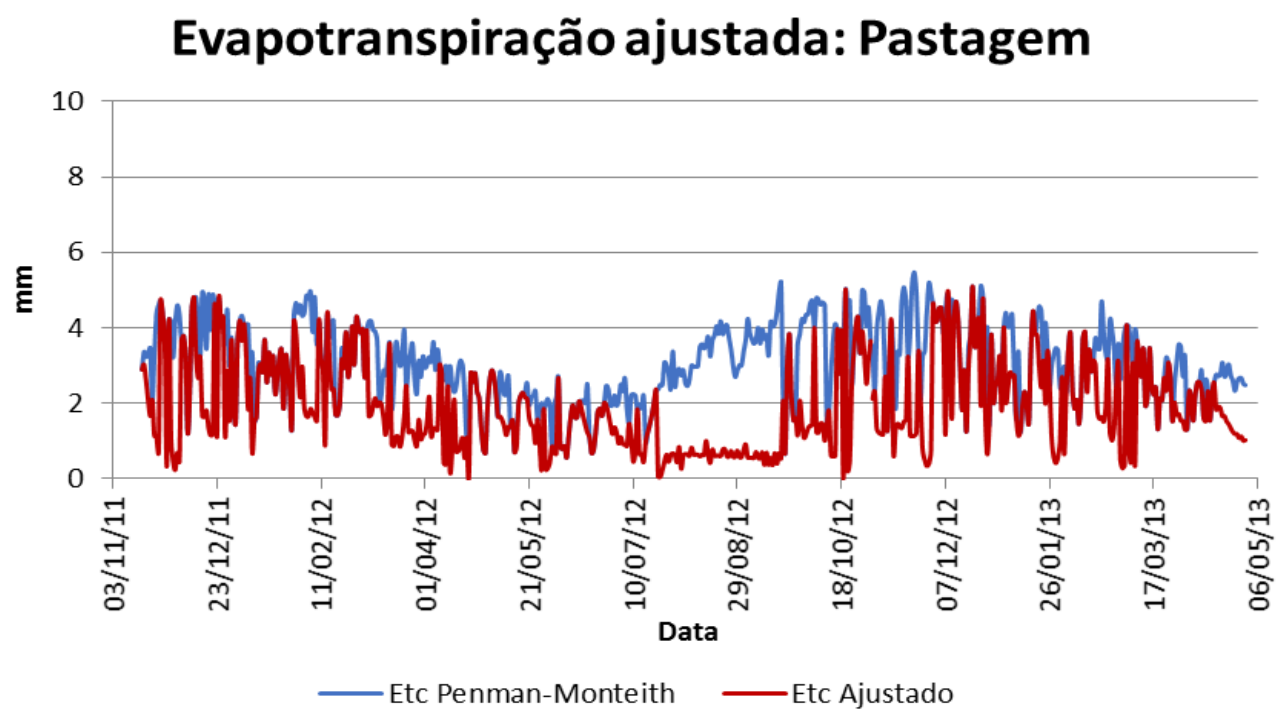

Evapotranspiração ajustada: Cana de açúcar

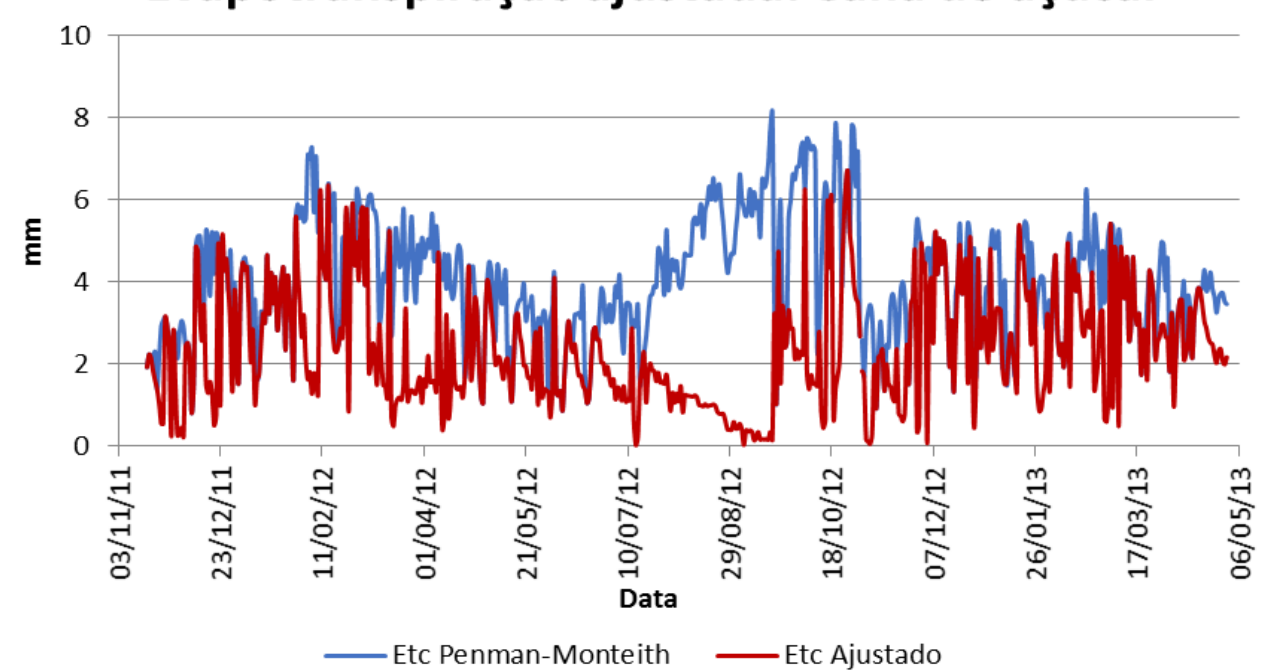

Figura 23 - Evapotranspiração ajustada em função da umidade do solo, medida por cultura. 
Ao comparar as evapotranspirações ajustadas das culturas, observa-se que as duas têm a mesma tendência, e os mesmos períodos em que a demanda hídrica é maior que a oferta. Destaca-se os maiores valores da evapotranspiração da cana-de-açúcar comparada com a pastagem, potenciais quanto ajustados. Esta situação é possível graças à maior umidade do solo, segundo o discutido anteriormente, o que sustenta uma maior evapotranspiração da cana-de-açúcar, mas não na pastagem.

Na época de seca (agosto de 2012), a pastagem evapotranspira a água disponível no solo até esgotá-la e depois mantém um nível estável de 0,5 $\mathrm{mm} \cdot \mathrm{dia}^{-1}$. Este valor foi calculado pela variação de umidade diária no solo até um metro de profundidade, onde pastagem tem pouca influência devido à reduzida profundidade do seu sistema de raízes e baixa atividade vegetativa nos meses de inverno. SILVEIRA et al. (2011), avaliaram em Piracicaba-SP a produção de raízes da Brachiaria decumbens até $40 \mathrm{~cm}$ de profundidade durante dois anos em Neossolo Quartzarênico similar ao solo do presente estudo, sob diferentes doses de adubação nitrogenada e enxofre. Seus resultados indicam que $83 \%$ do sistema de raízes encontra-se nos primeiros 20 $\mathrm{cm}$ do perfil do solo, independente do adubo ou da época chuvosa ou seca. Outro estudo referente ao crescimento da mesma braquiária em Coronel Pacheco-MG ao longo do ano e sob diferentes condições de sombra, apresentou sempre a diminuição da atividade vegetativa durante os meses de inverno, provocada pelas condições atmosféricas e de restrição hídrica (PACIULLO et al., 2008). Estes antecedentes indicam que os baixos valores de evapotranspiração na época de restrição hídrica seriam provocados somente por processos de evaporação ou percolação do solo, mais que devido à transpiração da cultura.

As raízes de cana-de-açúcar concentram-se nos primeiros $60 \mathrm{~cm}$ do solo, mas em períodos de escassez hídrica estas podem explorar ativamente níveis mais profundos (FARONI; TRIVELIN, 2006), encontrando-se em menor frequência a 1,8 m ou mais (BATTIE LACLAU; LACLAU, 2009; AZEVEDO; CHOPART; MEDINA, 2011). A diferença de evapotranspiração entre pastagem, cana-de-açúcar diminui gradualmente até $0,2 \mathrm{~mm}^{-d_{i a}-1}$ na época da seca (agosto 2012). Isso indica uma absorção ativa da umidade do solo por parte 
das raízes para transpiração até esgotar a água disponível no primeiro metro do perfil, o que já tinha sido identificado e discutido anteriormente nas variações de umidade a diferentes profundidades do solo.

Depois da colheita em novembro de 2012, observa-se um período de evapotranspiração ajustada menor que a calculada, mesmo quando o solo tinha umidade para satisfazer uma demanda maior de água. Esta situação pode ser consequência de uma redução da evaporação da superfície do solo, produzida pela palha que foi deixada a cada três entre-sulcos (justo do lado do sensor de umidade do solo), o que reduz a superfície exposta a desidratação, conforme o descrito por PERES; SOUZA; LAVORENTI (2010).

A pastagem teve uma evapotranspiração acumulada de $589,5 \mathrm{~mm}$ durante 0 primeiro ano de medições, e nos primeiros seis meses do segundo ano foi de 372,3 mm, equivalentes a 49\% das precipitações de cada período. Em canade-açúcar, estes valores são de 747,5 mm no primeiro ano, e 494,4 mm durante o segundo período, equivalente a $63 \%$ das precipitações.

BRITO; LIBARDI; GHIBERTO (2009) e GHIBERTO et al. (2011) estimaram a evapotranspiração em cana-de-açúcar como a incógnita dependente numa equação de balanço hídrico. Nesses trabalhos, a drenagem e a ascensão capilar foram calculadas pela equação Darcy-Buckingham, tendo valores com alto desvio padrão, o que é reconhecido pelos autores como uma fonte de erro importante que impede determinar com precisão a evapotranspiração da cultura. Neste ponto, é importante destacar que nesses estudos não considerou-se a interceptação do dossel e o escoamento. Por estes motivos, seus resultados de evapotranspiração estão na faixa de 850-1060 mm.ano-1.

\subsection{Percolação}

Os valores de percolação em cada cultura foram estimados pelo resíduo do balanço hídrico (Equação 1) e são apresentados na Figura 24. A percolação depende diretamente dos eventos de precipitação, portanto, maior precipitação ocasionará maior percolação. Todos os eventos diários foram considerados no balanço hídrico (aqueles com e sem escoamento), 180 deles apresentaram percolação em pastagem e só 154 em cana-de-açúcar. 


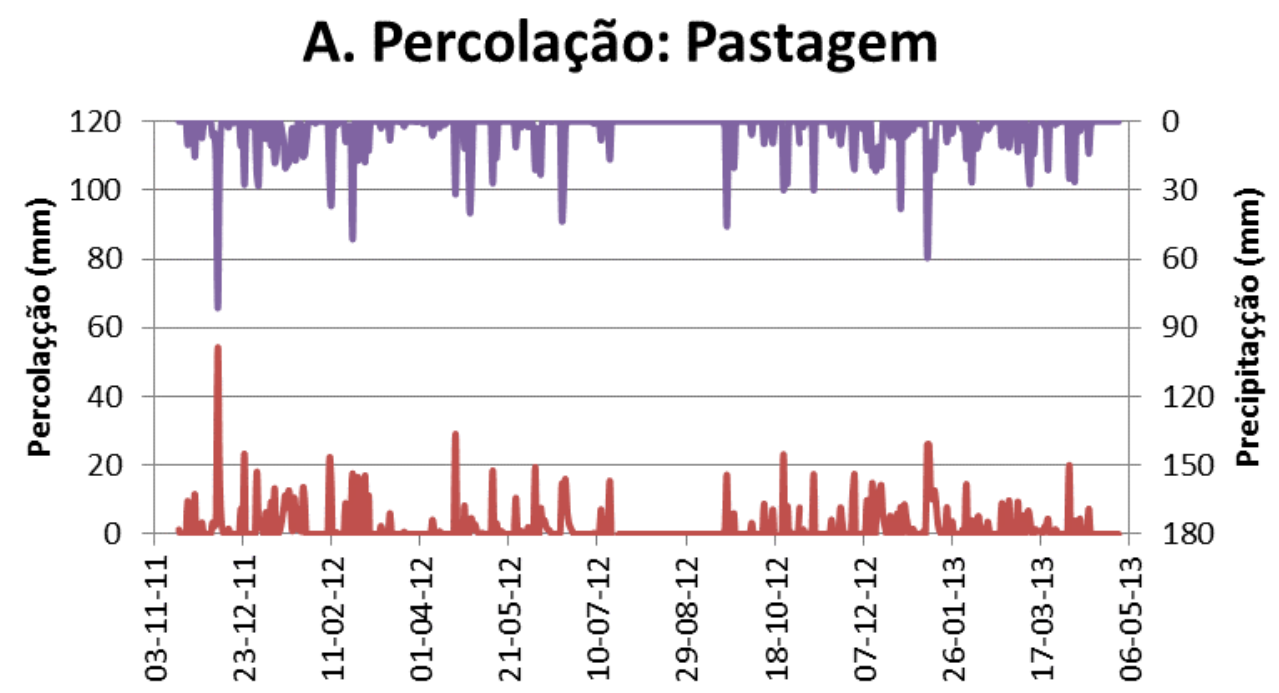

B. Percolação: Cana-de-Açúcar

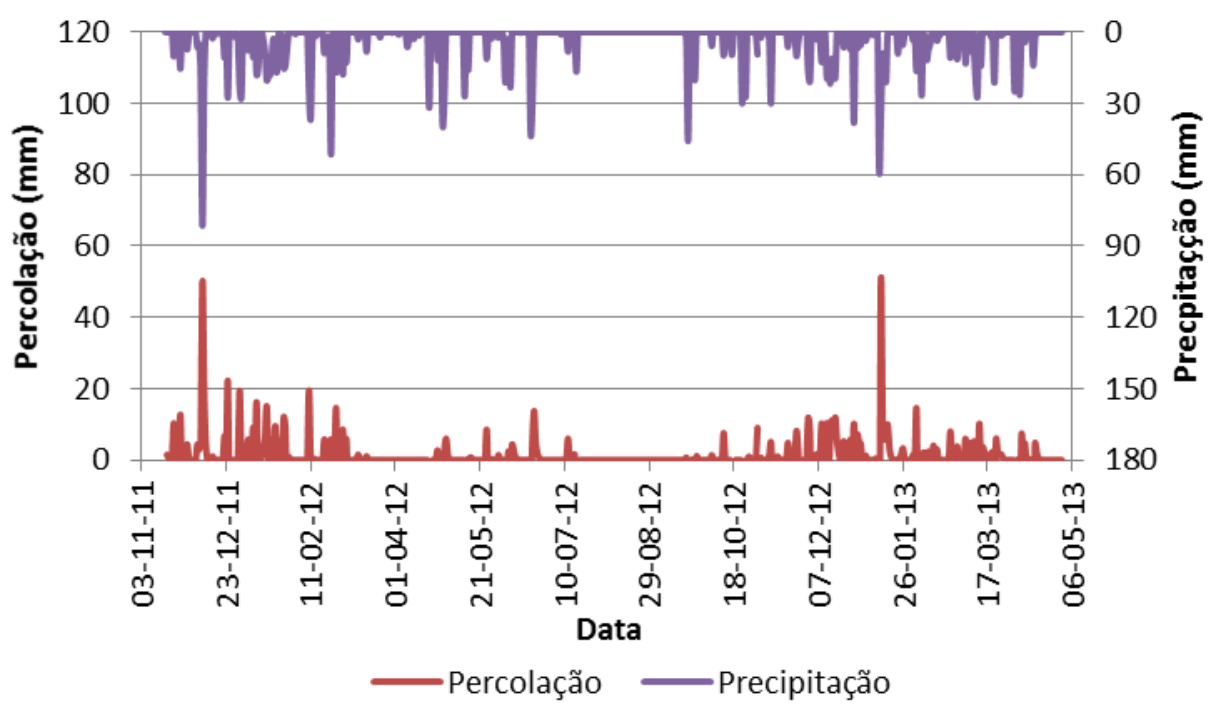

Figura 24 - Percolação através do primeiro metro do solo: sob pastagem (A); e, cana-de-açúcar (B).

A pastagem apresentou uma drenagem calculada de $568 \mathrm{~mm}$ durante 0 primeiro ano, e nos meses de novembro a abril do segundo ano foi de $362 \mathrm{~mm}$, equivalentes a 47 e $48 \%$ das precipitações do período, respectivamente. Em cana-de-açúcar, estes valores reduzem a $215 \mathrm{~mm}$ (18\%) no primeiro ano, e 105 mm (14\%) no segundo período. Observa-se que os valores em cana-deaçúcar são marcadamente menores de março até novembro de 2012, e de março de 2013 até o final das medições. Isto deve-se ao efeito da interceptação, que diminui a lâmina que infiltra no solo para percolação. A 
exceção é o evento do dia 12 de janeiro de 2013, correspondendo ao evento máximo registrado no período de estudo. Ao término dos 18 meses de medições, sob pastagem percolou 930 mm e sob cana-de-açúcar, 319 mm. Portanto, é possível afirmar que a substituição de pastagem por cana-deaçúcar diminuiu a percolação em $28 \%$ durante o período de estudo.

Poucos estudos de percolação em cana-de-açúcar ou pastagem foram desenvolvidos. BRITO; LIBARDI; GHIBERTO (2009) e GHIBERTO et al. (2011) estimaram a drenagem interna até $90 \mathrm{~cm}$ de profundidade sob cana-de-açúcar em Jaboticabal-SP, com diferentes doses e mistura de adubo, usando a equação de Darcy-Buckingham. Os valores obtidos apresentam alto desvio padrão, porém não são representativos. Seus resultados indicam valores de percolação entre 16 e $28 \%$ da precipitação durante 9 meses em que a temporada chuvosa está incluída.

\subsection{Balanço hídrico}

Uma vez quantificados todos os componentes do balanço hídrico (Equação 1), seus valores acumulados por período podem ser visualizados no gráfico da Figura 25. Precipitação, interceptação e escoamento apresentam-se com valores positivos, uma vez que são componentes que acontecem sobre a superfície do solo e sua diferença infiltra nele. Evapotranspiração e percolação apresentam-se como valores negativos, já que representam perdas de umidade do perfil do solo. Finalmente, a variação de umidade no solo tem valores tanto positivos quanto negativos, dependendo do ganho de umidade pelas precipitações, ou sua diminuição durante os períodos secos.

Além de todas as diferenças entre as culturas já analisadas para cada componente do balanço hídrico, destaca-se a baixa proporção que representa o escoamento superficial dentro do balanço anual, tanto em pastagem como em cana-de-açúcar. Neste último tratamento destaca o maior valor da interceptação comparado com o escoamento durante o primeiro ano. Estes dois fatores reduziram em $132 \mathrm{~mm}$ o volume que infiltrou sob cana-de-açúcar no citado período. 

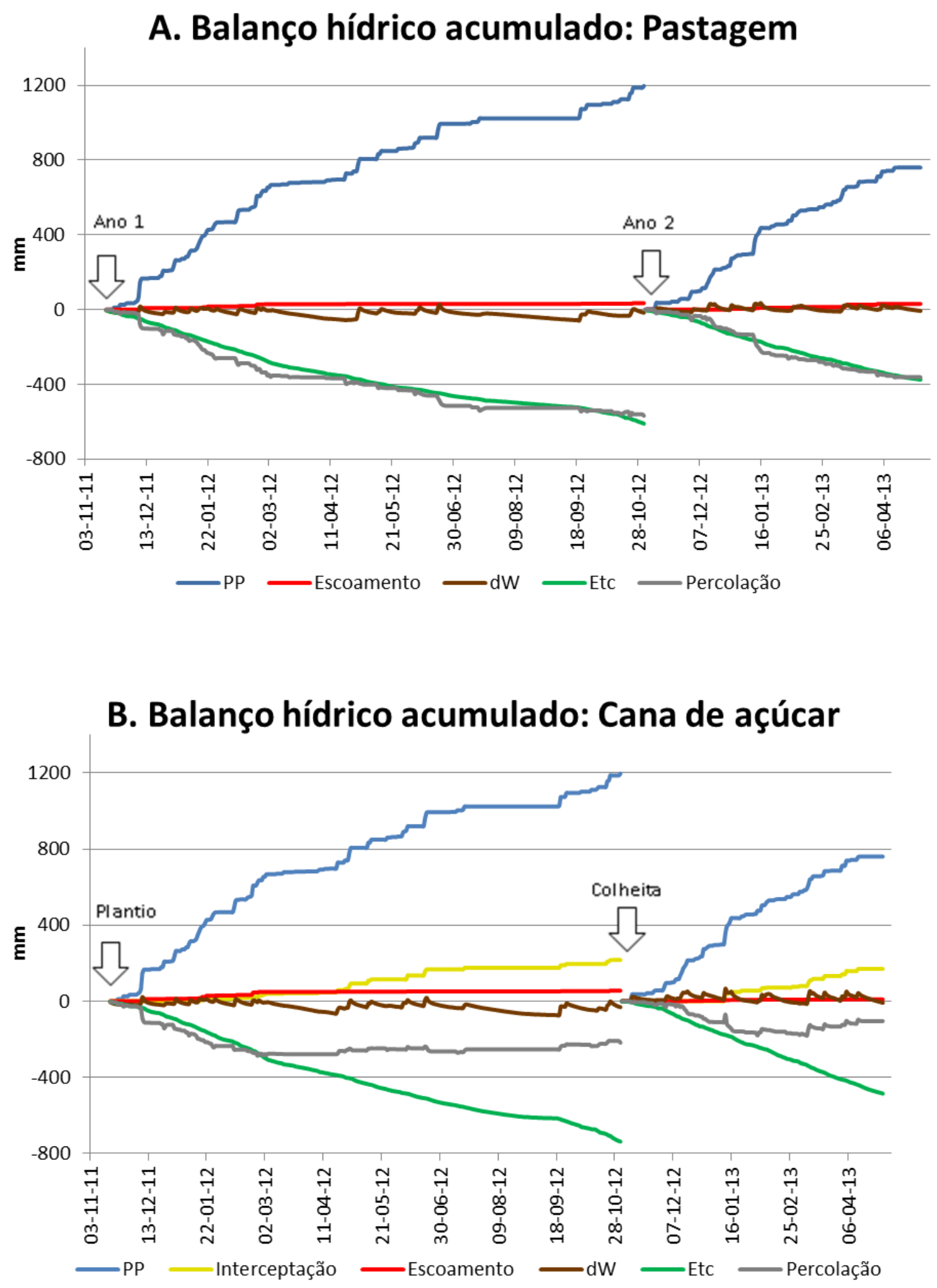

Figura 25 - Balanço hídrico acumulado para as culturas de pastagem (A) e cana-de-açúcar (B), durante os períodos de estudo. 
As variações de umidade no solo são próximas a zero, sugerindo que este componente do balanço tem um papel de buffer ou armazém temporário da lâmina de água no solo, e que pode ser desprezado em estudos que considerem o balanço em ciclos anuais. Ao observar em detalhe as curvas de variação de umidade, destaca-se a maior amplitude de valores abaixo de zero em cana-de-açúcar comparado com pastagem durante o primeiro ano. Esse fato deve-se à maior capacidade do solo para armazenar água, pois o gradeamento feito sob cana-de-açúcar aumentou a porosidade. Já durante os primeiros seis meses do segundo período de monitoramento, as variações de umidade em cana-de-açúcar adquirem uma maior amplitude nos valores positivos, o que reflete a maior infiltração de água por efeito dos cordões de palha deixados na superfície do solo a cada três entre-sulcos.

Referente a evapotranspiração e percolação, estes valores são similares em pastagem durante todo o período estudado. Sob cana-de-açúcar tem-se uma maior evapotranspiração acumulada e redução drástica da percolação a partir do mês de março em 2012 e de fevereiro em 2013. O gráfico da percolação acumulada em cana-de-açúcar é irregular, com tendência a diminuir seus valores, especialmente no segundo período. Isto explica-se por: i) o erro acumulado que esta variável recebe, uma vez que é calculado como o residual de valores médios na equação 1 . Neste ponto, influi diretamente 0 desconhecimento da fração da interceptação que atinge o solo pelo escoamento fustal; e ii) a umidade do solo é um valor calculado a partir de medições a três profundidades (30,60 e $90 \mathrm{~cm})$, justo na parcela com menor escoamento entre as repetições de cana-de-açúcar e pode, portanto, inserir erro no cálculo da percolação.

Ainda com estes antecedentes pode-se concluir que a substituição de pastagem por cana-de-açúcar sob as condições de clima e solo estudados, reduz a lâmina de água disponível para infiltração devido ao maior escoamento superficial e, principalmente, pela interceptação do dossel. Ao mesmo tempo provoca a diminuição da percolação no solo, reduzindo a recarga profunda do lençol freático. Esta situação foi descrita por LUCAS; GUANABARA; WENDLAND (2012) na bacia hidrográfica do Ribeirão da Onça, distante 8 km da área de estudo. Os autores utilizaram medições do nível de água 
subterrânea em poços de monitoramento, em cultura de pasto e cana, durante 7 anos, para determinar a recarga subterrânea pelo método do Water Table Fluctuation. 


\section{CONCLUSÕES}

Para avaliar o impacto da substituição de pastagem por cana-de-açúcar na produção de sedimentos e no balanço hídrico, foram construídas parcelas de escoamento sob as duas coberturas numa fazenda em Itirapina-SP. Nas parcelas foram medidas as perdas de solos, escoamento superficial e interceptação do dossel em cana-de-açúcar. Através de uma estação meteorológica instalada no local foram medidas as precipitações e a umidade de solo a 30, 60 e $90 \mathrm{~cm}$ de profundidade, e coletados os parâmetros necessários para calcular a evapotranspiração pelo método Penman-Monteith. Com estas medições, determinou-se o balanço hídrico diário para ambas coberturas até $1 \mathrm{~m}$ de profundidade.

Sob as condições experimentais do estudo, é possível afirmar que a erosão do solo é maior em cana-de-açúcar (Saccharum officinarum) do que em pastagem de Brachiaria decumbens durante os dois primeiros anos após a mudança da cultura. Os resultados em pastagem sob rotação de pasto mantêm-se em níveis abaixo de 0,002 Mg.ha-1.evento-1. Cana-de-açúcar provoca a maior perda de solo durante o primeiro ano (2,55 $\mathrm{Mg}^{-h^{-1}}$ ) devido ao plantio e quando o solo sob o dossel se manteve sem cobertura, e diminui no

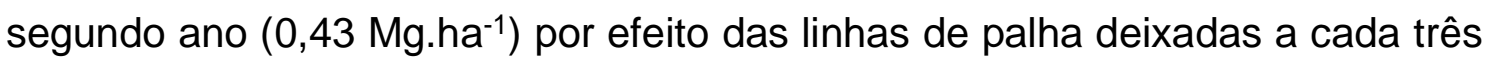
entre-sulcos.

A substituição de pastagem por cana-de-açúcar aumenta levemente o escoamento superficial no primeiro ano, mas no segundo ano ele se reduz por efeito das linhas de palha deixadas na superfície do solo a cada três entresulcos. O escoamento representa uma baixa proporção, comparado com outros componentes do balanço hídrico. Os eventos com maior escoamento acontecem em situações de: i) alta pluviometria (>15 mm/evento), ii) períodos de chuvas muito frequentes, ou iii) eventos de alta intensidade (maiores que 5 $\mathrm{mm} .10 \mathrm{~min}^{-1}$ ). Chuvas com lâminas maiores que $6 \mathrm{~mm}$ devem ser monitoradas como possíveis geradoras de escoamento. 
A interceptação do dossel da cana-de-açúcar começa a se manifestar no mês de janeiro, dois meses depois do plantio ou colheita. A partir do mês de março, a interceptação atinge um mínimo estável de $40 \%$ da precipitação total. No entanto, neste valor não foi avaliado o escoamento pelos colmos.

O gradeamento em cana-de-açúcar favorece a umidade do solo, comparado com pastagem, uma vez que aumenta a porosidade do perfil. As variações de umidade no solo são próximas a zero ao longo do ano, o que sugere que este componente do balanço tem um papel de buffer ou armazém temporário da lâmina de água no solo, e que poderia ser desprezado em estudos que considerem o balanço em ciclos anuais.

A maior evapotranspiração de cana-de-açúcar é suportada pela maior umidade do solo, comparado com pastagem. Após a colheita e durante um mês, cana-de-açúcar evapotranspira menos que o calculado pelo método de Penman-Monteith devido à redução da evaporação do solo, protegido pela palha.

A percolação foi determinada pelo resíduo da equação de balanço hídrico. A substituição de pastagem por cana-de-açúcar reduz a percolação de água abaixo do primeiro metro de profundidade. Esta redução é devida, principalmente, ao efeito da interceptação e maior evapotranspiração da cultura.

Sob as condições experimentais do estudo, é possível afirmar que a substituição de pastagem por cana-de-açúcar aumenta a erosão e modifica o balanço hídrico. Muitos destes impactos reduzem durante o segundo ano com o uso de linhas de palha a cada três entre-sulcos de cana-de-açúcar. 


\section{REFERÊNCIAS BIBLIOGRÁFICAS}

ADAMI, M.; RUDORFF, B. F. T.; FREITAS, R. M.; AGUIAR, D. A.; SUGAWARA, L. M.; MELLO, M. P. Remote Sensing Time Series to Evaluate Direct Land Use Change of Recent Expanded Sugarcane Crop in Brazil. Sustainability, v. 4, n. 4, p. 574-585, 2012.

ALLEN, R. G.; PEREIRA, L. S.; RAES, D.; SMITH, M. Crop evapotranspiration-Guidelines for computing crop water requirementsFAO Irrigation and drainage paper 56, 1998, v.300. 6541 p. (FAO, Rome).

AMORIM, R. S. S.; SILVA, D. D. D.; PRUSKI, F. F.; MATOS, A. T. D. Avaliação do desempenho dos modelos de predição da erosão hídrica USLE, RUSLE e WEPP para diferentes condições edafoclimáticas do Brasil. Engenharia Agrícola, v. 30, n., p. 1046-1049, 2010.

ANDRADE, N. S. F. D.; MARTINS FILHO, M. V.; TORRES, J. L. R.; PEREIRA, G. T.; MARQUES JÚNIOR, J. Impacto técnico e econômico das perdas de solo e nutrientes por erosão no cultivo da cana-de-açúcar. Engenharia Agrícola, v. 31, n., p. 539-550, 2011.

AZADI, H.; DE JONG, S.; DERUDDER, B.; DE MAEYER, P.; WITLOX, F. Bitter sweet: How sustainable is bio-ethanol production in Brazil? Renewable and Sustainable Energy Reviews, v. 16, n. 6, p. 3599-3603, 2012.

AZEVEDO, M. C. B. D.; CHOPART, J. L.; MEDINA, C. D. C. Sugarcane root length density and distribution from root intersection counting on a trenchprofile. Scientia Agricola, v. 68, n., p. 94-101, 2011.

BARROS, A. C. Utilização do modelo CANEGRO para estimativa da produtividade de cana-de-açúcar irrigada em diferentes regiões do Brasil. Escola Superior de Agricultura Luiz de Queiroz, Universidade de São Paulo, Piracicaba, 2011.

BATTIE LACLAU, P.; LACLAU, J. P. Growth of the whole root system for a plant crop of sugarcane under rainfed and irrigated environments in Brazil. Field Crops Research, v. 114, n. 3, p. 351-360, 2009.

BEZERRA, S. A.; CANTALICE, J. R. B. Erosão entre sulcos em diferentes condições de cobertura do solo, sob cultivo da cana-de-açúcar. Revista Brasileira de Ciência do Solo, v. 30, n., p. 565-573, 2006.

BRAMORSKI, J.; DE MARIA, I. C.; SILVA, R. L. E.; CRESTANA, S. Relations between soil surface roughness, tortuosity, tillage treatments, rainfall intensity 
and soil and water losses from a red yellow latosol. Revista Brasileira de Ciência do Solo, v. 36, n., p. 1291-1298, 2012.

BRANDÃO, V. D. S.; SILVA, D. D. D.; RUIZ, H. A.; PRUSKI, F. F.; SCHAEFER, C. E. G. R.; MARTINEZ, M. A.; SILVA, E. O. Perdas de solo e caracterização física e micromorfológica de crostas formadas em solos sob chuva simulada. Engenharia Agrícola, v. 27, n., p. 129-138, 2007.

BRITO, A. D. S.; LIBARDI, P. L.; GHIBERTO, P. J. Componentes do balanço de água no solo com cana-de-açúcar, com e sem adubação nitrogenada. Revista Brasileira de Ciência do Solo, v. 33, n., p. 295-303, 2009.

CASANELLAS, J. P. Edafologial Edaphology: Para La Agricultura Y El Medio Ambiente: Ediciones Mundi-Prensa, 2003.

CASTILHO, C. P. G. A. D. Interceptação de chuvas na cultura da cana-deaçucar (Saccharum Officinarum ssp.). Faculdade de Engenharia Agrícola, Universidade Estadual de Campinas, 2000. 256 p.

DA SILVA, V. D. P. R.; DA SILVA, B. B.; ALBUQUERQUE, W. G.; BORGES, C. J. R.; DE SOUSA, I. F.; NETO, J. D. Crop coefficient, water requirements, yield and water use efficiency of sugarcane growth in Brazil. Agricultural Water Management, v. 128, n., p. 102-109, 2013.

DOORENBOS, J.; PRUITT, W. O.; ABOUKHALED, A. Guidelines for Predicting Crop Water Requirements. Rome: Food and Agriculture Organization of the United Nations, 1975 (FAO irrigation and drainage paper. Vol 24 ).

DOORENBOS, J.; KASSAM, A. H.; BENTVELSEN, C. I. M. Yield response to water. Rome: Food and Agriculture Organization of the United Nations, 1979. 193 p. (FAO irrigation and drainage paper. Vol 33).

DRUGOWICH, M. I.; SAVASTANO, S.; LIMA SAVASTANO, S. A. A. D. Erosão em pastagens sob pecuária leiteira e mista no estado de São Paulo. Coordenadoria de Assistência Técnica Integral. Instituto de Economia Agrícola, 2009.

ECHEVERRÍA, C.; HUBER, A.; TABERLET, F. Estudio comparativo de los componentes del balance hídrico en un bosque nativo y una pradera en el sur de Chile. Bosque (Valdivia), v. 28, n., p. 271-280, 2007.

FAO. FAOSTAT Production Crops 2011. 2013. 
FARONI, C. E.; TRIVELIN, P. C. O. Quantificação de raízes metabolicamente ativas de cana-de-açúcar. Pesquisa Agropecuária Brasileira, v. 41, n., p. 1007-1013, 2006.

FELLER, M. C. Water balance in Eucalyptus regnans, E.obliqua, and Pinus radiata forests in Victoria. Australian Forestry, v. 44, n. 3, p. 153-161, 1981.

GALHARTE, C. A. Estimativa do escorrimento superficial e da produção de sedimentos em áreas de atividades agrossilvopastoris, no Estado de São Paulo, em função da mudança de uso e cobertura do solo. Escola de Engenharia de São Carlos, Universidade de São Paulo, Universidade de São Paulo, São Carlos, 2011.

GARBIATE, M. V.; VITORINO, A. C. T.; TOMASINI, B. A.; BERGAMIN, A. C.; PANACHUKI, E. Erosão em entre sulcos em área cultivada com cana crua e queimada sob colheita manual e mecanizada. Revista Brasileira de Ciência do Solo, v. 35, n., p. 2145-2155, 2011.

GHIBERTO, P. J.; LIBARDI, P. L.; BRITO, A. S.; TRIVELIN, P. C. O. Components of the water balance in soil with sugarcane crops. Agricultural Water Management, v. 102, n. 1, p. 1-7, 2011.

HUDSON, N. W. Medición sobre el terreno de la erosión del suelo y de la escorrentía. Roma: FAO, 1997 (Boletín de suelos de la FAO, 68).

IEA. Série Informações Estadísticas da Agricultura SP. Anuário Instituto de Economía Agrícola 2007. 2008.

IEA. Série Informações Estadísticas da Agricultura SP. Anuário Instituto de Economía Agrícola 2011. 2012.

INMET. Normais Climatológicas do Brasil 1961-1990. 2013.

KIRKBY, J.; MORGAN, R. P. C. Soil erosion: Wiley, 1980.

LAL, R. Soil degradation by erosion. Land Degradation \& Development, v. 12, n. 6, p. 519-539, 2001.

LELIS, T. A.; CALIJURI, M. L.; SANTIAGO, A. D. F.; LIMA, D. C. D.; ROCHA, E. D. O. Análise de sensibilidade e calibração do modelo SWAT aplicado em bacia hidrográfica da região sudeste do Brasil. Revista Brasileira de Ciência do Solo, v. 36, n., p. 623-634, 2012.

LIBARDI, P. L. Dinâmica da Água no Solo Vol. 61: Edusp, 2005. 
LUCAS, M.; GUANABARA, R.; WENDLAND, E. Estimativa de recarga subterrânea em área de afloramento do Sistema Aquífero Guarani. Boletín geológico y minero, v. 123, n. 3, p. 311-323, 2012.

LYRA, G. B.; DA SILVEIRA, E. L.; LYRA, G. B.; PEREIRA, C. R.; DA SILVA, L. D. B.; DA SILVA, G. M. Sugarcane crop coefficient for the initial growth stage in Campos dos Goytacazes, State of Rio de Janeiro, Brazil. Coeficiente da cultura da cana-de-açúcar no estádio inicial de desenvolvimento em Campos dos Goytacazes, RJ, v. 17, n. 1, p. 102-113, 2012.

MARTINELLI, L.; FILOSO, S. Expansion of sugarcane ethanol production in Brazil: environmental and social challenges. Ecological Applications, v. 18, n. 4, p. 885-898, 2008.

MARTINS FILHO, M. V.; LICCIOTI, T. T.; PEREIRA, G. T.; MARQUES JÚNIOR, J.; SANCHEZ, R. B. Perdas de solo e nutrientes por erosão num Argissolo com resíduos vegetais de cana-de-açúcar. Engenharia Agrícola, v. 29, n., p. 8-18, 2009.

MINOTI, R. Abordagens qualitativa e quantitativa de micro-bacias hidrográficas e áreas alagáveis de um compartimento do Médio MogiSuperior/SP. 2006. 231f. Tese (Doutorado em Ciências da Engenharia Ambiental)-Escola de Engenharia de São Carlos, Universidade de São Paulo, São Carlos, 2006.

MORGAN, R. P. C. Soil Erosion and Conservation: Wiley, 2009.

OLIVETTI, M.; CASTANHO FILHO, E.; SACHS, R.; NACHILUK, K.; MARTINS, R.; CAMARGO, F.; ANGELO, J.; OLIVEIRA, L. Evolução e prospecção da agricultura paulista: liberação da área de pastagem para o cultivo da canade-açúcar, eucalipto, seringueira e reflexos na pecuária, 1996-2030, 2011 (São Paulo: Instituto de Economia Agrícola).

PACIULLO, D. S. C.; CAMPOS, N. R.; GOMIDE, C. A. M.; CASTRO, C. R. T. D.; TAVELA, R. C.; ROSSIELLO, R. O. P. Crescimento de capim-braquiária influenciado pelo grau de sombreamento e pela estação do ano. Pesquisa Agropecuária Brasileira, v. 43, n., p. 917-923, 2008.

PERALTA, M. P. Uso, clasificación y conservación de suelos. Santiago, Chile: Ed. Servicio Agricola y Ganadero, 1976.

PERES, J. G.; SOUZA, C. F.; LAVORENTI, N. A. Avaliação dos efeitos da cobertura de palha de cana-de-açúcar na umidade e na perda de água do solo. Engenharia Agrícola, v. 30, n., p. 875-886, 2010. 
PRADO, W. L. D.; VEIGA, M. D. Relacion entre erosion y perdida de fertilidad del suelo; Relationship between erosion and loss of soil fertility. Santiago, Chile: FAO, 1994.

RUDORFF, B. F. T.; AGUIAR, D. A.; SILVA, W. F.; SUGAWARA, L. M.; ADAMI, M.; MOREIRA, M. A. Studies on the Rapid Expansion of Sugarcane for Ethanol Production in São Paulo State (Brazil) Using Landsat Data. Remote Sensing, v. 2, n. 4, p. 1057-1076, 2010.

SALAS, G. D. L. Suelos y ecosistemas forestales: con énfasis en América tropical. San José, Costa Rica: Inst. Interamericano de Cooperación para la Agricultura, 1987. 450 p. (Colección Libros y materiales educativos, Nr. 80).

SENTEK. Calibration Manual for Sentek Soil Moisture Sensors. Rev. 2.0.: secondary title. Stepney, South Australia: Sentek Pty Ltd., 2011, 56 p.

SILVA, A. M. D.; RANZINI, M.; GUANDIQUE, M. E. G.; ARCOVA, F. C. S.; CICCO, V. D. Estudo Integrado do processo erosivo numa microbacia experimental localizada no município de Cunha - SP. Geociências, UNESP, v. 24, n. 1, p. 43-53, 2005.

SILVA, G. R. V. D.; SOUZA, Z. M. D.; MARTINS FILHO, M. V.; BARBOSA, R. S.; SOUZA, G. S. D. Soil, water and nutrient losses by interrill erosion from green cane cultivation. Revista Brasileira de Ciência do Solo, v. 36, n., p. 963-970, 2012.

SILVEIRA, C. P.; OLIVEIRA, D. A. D.; BONFIM-SILVA, E. M.; MONTEIRO, F. A. Two years of nitrogen and sulfur fertilizations in a signal grass pasture under degradation: changes in the root system. Revista Brasileira de Zootecnia, v. 40, n., p. 1195-1203, 2011.

SOUSA, G. B.; MARTINS FILHO, M. V.; MATIAS, S. S. R. Perdas de solo, matéria orgânica e nutrientes por erosão hídrica em uma vertente coberta com diferentes quantidades de palha de cana-de-açúcar em Guariba - SP. Engenharia Agrícola, v. 32, n., p. 490-500, 2012.

SPAROVEK, G.; SCHNUG, E. Temporal Erosion-Induced Soil Degradation and Yield Loss. Soil Sci Soc Am J, v. 65, n. 5, p. 1479-1486, 2001.

TEIXEIRA, E. N.; MANTOVANI, E. C.; VIEIRA, G. H. S.; COELHO, M. B.; FERNANDES, A. L. T. Interceptação de água pelo dossel da cana-de-açúcar. Irriga, v. 17, n. 1, p., 2012. 
TIMM, L. C.; OLIVEIRA, J. C. M. D.; TOMINAGA, T. T.; CÁSSARO, F. A. M.; REICHARDT, K.; BACCHI, O. O. S. Water balance of a sugarcane crop: quantitative and qualitative aspects of its measurement. Revista Brasileira de Engenharia Agrícola e Ambiental, v. 6, n., p. 57-62, 2002.

TOMASINI, B. A.; VITORINO, A. C. T.; GARBIATE, M. V.; SOUZA, C. M. A. D.; A. SOBRINHO, T. Infiltração de água no solo em áreas cultivadas com canade-açúcar sob diferentes sistemas de colheita e modelos de ajustes de equações de infiltração. Engenharia Agrícola, v. 30, n., p. 1060-1070, 2010.

TOY, T. J.; FOSTER, G. R.; RENARD, K. G. Soil erosion: processes, prediction, measurement, and control. New York: John Wiley \& Sons, 2002. $338 \mathrm{p}$.

UNICA. Dados e Cotações - Estatísticas. União da Indústria de Cana-deAçúcar. 2013.

VEIGA, M. D.; PRADO, W. L. D. Manual para la instalación y conducción de experimentos de pérdidas de suelos. Santiago de Chile: FAO, 1993

WALTER, A.; DOLZAN, P.; QUILODRÁN, O.; DE OLIVEIRA, J. G.; DA SILVA, C.; PIACENTE, F.; SEGERSTEDT, A. Sustainability assessment of bio-ethanol production in Brazil considering land use change, GHG emissions and socioeconomic aspects. Energy Policy, v. 39, n. 10, p. 5703-5716, 2011.

WEILL, M. D. A. M.; SPAROVEK, G. Estudo da erosão na microbacia do Ceveiro (Piracicaba, SP): I - Estimativa das taxas de perda de solo e estudo de sensibilidade dos fatores do modelo EUPS. Revista Brasileira de Ciência do Solo, v. 32, n., p. 801-814, 2008.

WISCHMEIER, W. H.; SMITH, D. D. Predicting rainfall erosion losses: a guide to conservation planning. Washington DC, USA: Handbook No. 537 USDA Agricultural Service, 1978. 58 p. 


\section{ANEXO 1 Resultados de Análise Físico de Solos}




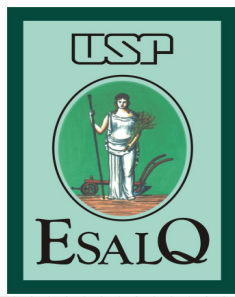

Universidade de São Paulo

Escola Superior de Agricultura "Luiz de Queiroz"

Departamento de Ciência do Solo

Interessado:

2490 Edson Cezar Wendland

Endereço:

AV Trabalhador Sancarlense 400

Centro Sao Carlos SP CEP 13566590

Propriedade: Conquista Município: Itirapina - SP
Tipo de Análise: SF3

Requisição:

2914

Data de Emissão: 20/3/2012

Material analisado: Terra

Concluídas em: $\quad$ 14/3/2012

\section{Resultado de Análise Granulométrica}

\begin{tabular}{|c|c|c|c|c|c|c|c|c|c|c|c|}
\hline \multirow{2}{*}{$\begin{array}{l}\text { Identif. da } \\
\text { Amostra }\end{array}$} & \multicolumn{6}{|c|}{ Areias $(\mathbf{g} / \mathbf{k g})$} & \multirow{2}{*}{$\begin{array}{l}\text { Silte } \\
(\mathrm{g} / \mathrm{kg})\end{array}$} & \multicolumn{2}{|c|}{ Argilas (g/kg) } & \multirow{2}{*}{$\begin{array}{l}\text { Flocula- } \\
\text { ção (\%) }\end{array}$} & \multirow{2}{*}{$\begin{array}{c}\text { Classe de } \\
\text { Textura }\end{array}$} \\
\hline & AMG & $A G$ & $\mathrm{AM}$ & AF & AMF & AT & & c/disp. & água & & \\
\hline $0-14 \mathrm{~cm}$ & 16 & 22 & 158 & 349 & 333 & 879 & 33 & 88 & 51 & 43 & ar. \\
\hline $30 \mathrm{~cm}$ & 5 & 31 & 223 & 518 & 87 & 865 & 34 & 101 & 76 & 25 & ar. \\
\hline $60 \mathrm{~cm}$ & 5 & 32 & 224 & 494 & 90 & 844 & 30 & 126 & 76 & 40 & ar. \\
\hline $90 \mathrm{~cm}$ & 4 & 31 & 227 & 485 & 90 & 836 & 39 & 125 & 25 & 80 & ar. \\
\hline
\end{tabular}

Métodos: Bouyoucos (densímetro); S.S.S.A. Book Series: 5 Methods of Siol Analysis Part4;

Classe de diametro $(\mathrm{mm})$ U.S.D.A..

5 frações de areia: muito grossa $(M G)=2$ a 1 ; grossa $(G)=1$ a 0,5 ; média $(M)=0,5$ a 0,25 ;

fina $(F)=0,25$ a 0,10 ; muito fina $(M F)=0,10$ a 0,05 ; areia total $(A T)=2$ a 0,05 ;

silte $=0,05$ a 0,002 ; argila total $<0,002$; argila água $<0,002$.

2 frações de areia: grossa $(G)=2$ a 0,25 e fina $(F)=0,25$ a 0,05 ; areia total $(A T)=2$ a 0,05

silte $=0,05$ a 0,002 ; argila total $<0,002$.

Classe de textura: Argila (c/ dispersante) até $149 \mathrm{~g} / \mathrm{kg}$ = arenosa (ar); de 150 a $249 \mathrm{~g} / \mathrm{kg}$

= média arenosa (md-ar); de 250 a $349 \mathrm{~g} / \mathrm{kg}$ = média argilosa (md-arg);

de 350 a $599 \mathrm{~g} / \mathrm{kg}=$ argilosa (arg); de $600 \mathrm{~g} / \mathrm{kg}$ ou superior - muito argilosa (m-arg).

Observações:

Amostra coletada pelo interessado; ( \# ) elemento não determinado.

Este documento pode ser reproduzido somente por completo.

Os resultados deste relatório se referem somente às amostras enviadas ao laboratório. 


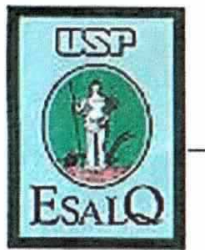

Cliente:

Endereço:

Cidade:
UNIVERSIDADE DE SÃo PAULO

ESCOLA SUPERIOR DE AGRICULTURA "LUIZ DE QUEIROZ"

DEPARTAMENTO DE CIÊNCIA DO SOLOS

Av. Pádua Dias, 11 - CEP 13418-900 • Piracicaba, SP - Brasi

Fone (19) $3417-2117 \cdot$ Fax (19) 34172135

http://www.solos.esalq.usp.br

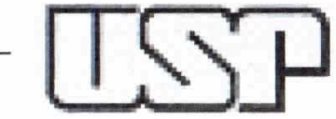

\section{Edson Cezar Wendland}

Av. Trabalhador São Carlense, centro (Departamento de Hidráulica)

$N^{\circ} 400$

Estado: SP

RESULTADOS DE ANÁLISES

Retenção de água no solo

\begin{tabular}{|c|c|c|c|c|c|c|c|c|c|c|c|}
\hline \multirow{4}{*}{$\mathbf{N}^{0}$ Lab. } & \multirow{4}{*}{ Identificação } & \multicolumn{7}{|c|}{ Retenção de água no solo } & \multirow{3}{*}{ DS } & \multirow{3}{*}{ DP } & \multirow{3}{*}{$\begin{array}{l}\text { Condutividade } \\
\text { Hidráulica }\end{array}$} \\
\hline & & \multicolumn{4}{|c|}{ Potencial (-bar) } & \multicolumn{3}{|c|}{ Porosidade } & & & \\
\hline & & UC & 0,06 & 0,33 & 15,00 & Total & Macro & Micro & & & \\
\hline & & \multicolumn{7}{|c|}{ - } & \multicolumn{2}{|c|}{ - $\mathrm{g} \mathrm{cm}^{-3}$} & $\mathrm{~mm} \mathrm{~h}^{-1}$ \\
\hline R.2914/1 & $(01) 30 \mathrm{~cm}$ & 0,0997 & 0,1962 & 0,0927 & 0,0873 & 0,3788 & 0,1826 & 0,1962 & 1,64 & 2,64 & 147,31 \\
\hline R.2914/2 & (02) $60 \mathrm{~cm}$ & 0,0878 & 0,2069 & 0,0854 & 0,0858 & 0,4226 & 0,2157 & 0,2069 & 1,53 & 2,65 & 117,01 \\
\hline R. $2914 / 3$ & (03) $90 \mathrm{~cm}$ & 0,1108 & 0,2065 & 0,0887 & 0,0801 & 0,4264 & 0,2199 & 0,2065 & 1,52 & 2,65 & 129,34 \\
\hline
\end{tabular}

UC, umidade de campo; DS, densidade do solo; DP; densidade de partículas.

Piracicaba, 13 de março de 2012.

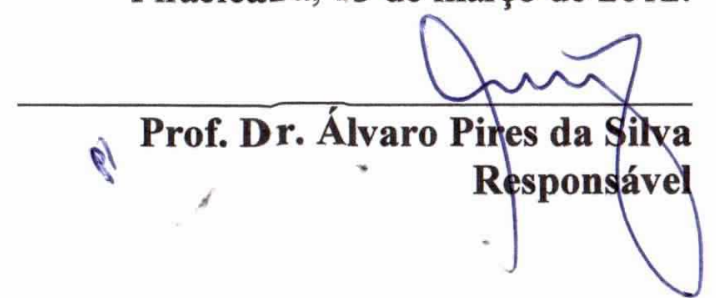


ANEXO 2

WebSite Estação Meteorológica

LHC-IAB 


\section{IHC Laboratório de Hidráulica Computacional}

\section{Condições Metereológicas Online - Estação LHC-IAB}

\section{Condições Metereológicas Online}

\section{Estação LHC-IAB}

Fazenda São Jose - Sector Broa - Itirapina/SP

Coordenadas WGS 1984: 23k 205802m E 7543956m S

Altitude: $790 \mathrm{msnm}$

Intervalo de coleta de dados: 10 minutos

Contato: ew@sc.usp.br

\section{Geração de dados compilados por período}

Dados de:

29/06/2013 até $29 / 06 / 2013$
ncluir colunas:
$\nabla$ Data - Hora
$\square$ Temperatura $\left({ }^{\circ} \mathrm{C}\right)$
$\square$ Umidade relativa (\%)
$\square$ Pressão (mbar)
D Precipitação $(\mathrm{mm})$
$\square$ Velocidade do vento $(\mathrm{m} / \mathrm{s})$
Direção do vento $\left({ }^{\circ}\right)$
Irradiância $(\mathrm{kW} / \mathrm{m} 2)$
Radiação $(\mathrm{MJ} / \mathrm{m} 2)$
Etos (mm)
Radiação com ceu limpo (MJ/m2)
Carregar Dados

Idioma

Português, Brasil
Umidade solo $30 \mathrm{~cm}$ - Pastagem (\%)

Umidade solo $60 \mathrm{~cm}$ - Pastagem (\%)

Umidade solo $90 \mathrm{~cm}$ - Pastagem (\%)

Umidade solo $30 \mathrm{~cm}$ - Cana-de-açúcar (\%)

Umidade solo $60 \mathrm{~cm}$ - Cana-de-açúcar (\%)

Umidade solo $90 \mathrm{~cm}$ - Cana-de-açúcar (\%)

Umidade solo $20 \mathrm{~cm}$ - Solo exposto (\%)

Diferença entre nivel freatico e $40 \mathrm{~m}(\mathrm{~m})$

Bateria (V)
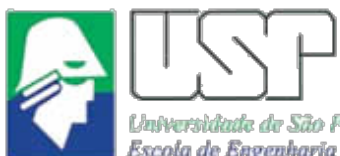

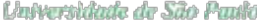

Escola de Engenharia de sâo Carlas

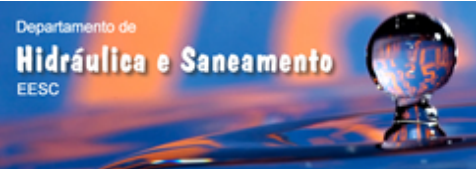

POS-GRADUAÇ,AO ET ENGENHARIA

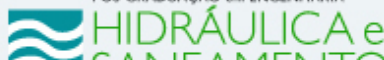

2 SANEAMENTO

PPG-SHS USPISÁO CARLOS

\section{Galeria de Fotos}

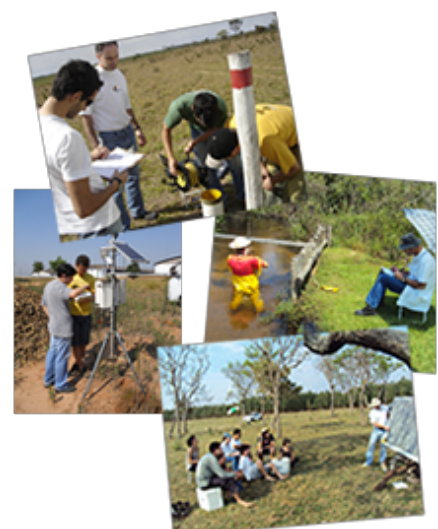

Docente Responsável

Prof. Tit. Edson C. Wendland

ew@sc.usp.br

Currículo Lattes

\section{Últimas Defesas de dissertações de mestrado / teses de doutorado}

11/07/2013 - Mestrado: Antonio Alves Meira Neto

"ANÁLISE DE INCERTEZAS E PONDERAÇÃO BAYESIANADE MODELOS APLICADAS À MODELAGEM CHUVA-VAZÃO DA BACIA DO RIBEIRÃO DA ONÇA"

03/07/2013 - Mestrado: Davi de Carvalho Diniz Melo

"ESTIMATIVA DE IMPACTO DE MUDANÇAS CLIMÁTICAS NOS NÍVEIS DO AQUIFFERO LIVRE EM ZONADE RECARGA DO SISTEMA AQUÍFERO GUARANI"

01/06/2012 - Mestrado: Aline da Silva Ribeiro

"Modelagem Chuva-Vazão Utilizando Framework JAMS em Área de Afloramento do Sistema Aquífero Guarani"

Defesas anteriores ...

\section{Estação LHC-IAB}

Última Atualização

Dia: 29/06/2013 / Hora: 01:30

Temperatura: $16.44^{\circ} \mathrm{C}$

Umidade relativa: $94.6 \%$

Pressão: 924 mbar

Precipitação: $\mathbf{0}$ mm

Precipitação acumulada (24h): 0mm

Velocidade do vento: $0.189 \mathrm{~m} / \mathrm{s}$

Direção do vento: $352.7^{\circ}$

Radiação: "NAN" MJ/m2

Bateria: $12.3 \mathrm{~V}$

Saiba mais .. 
ANEXO 3

Lavouras

Aplicadas para

Estabelecer e

Explorar o Plantio

de Cana-de-

Açúcar 
Anexo 3: Trabalhos e lavouras para estabelecer e explorar o plantio de cana-de-açúcar.

\section{Plantio}

1.1 Gradagem do solo até $30 \mathrm{~cm}$ de profundidade. 4 passagens.

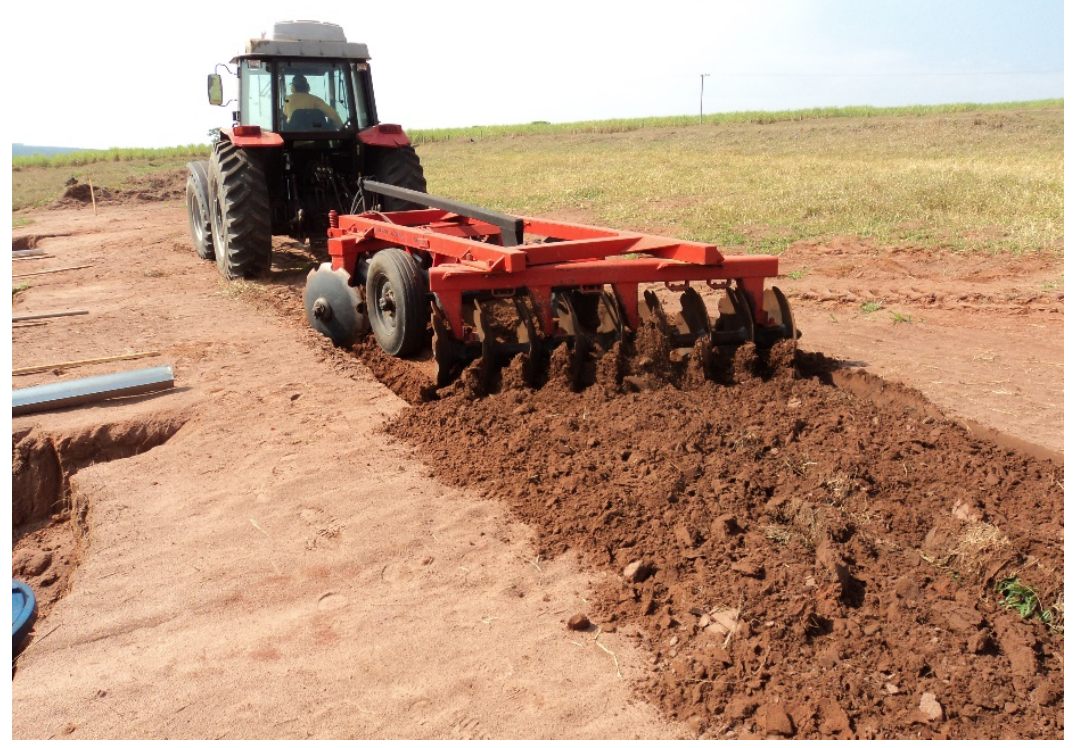

1.2 Sulcagem do solo em curva de nível. $15-20 \mathrm{~cm}$ de profundidade, 17 sulcos distanciados a $1,5 \mathrm{~m}$.

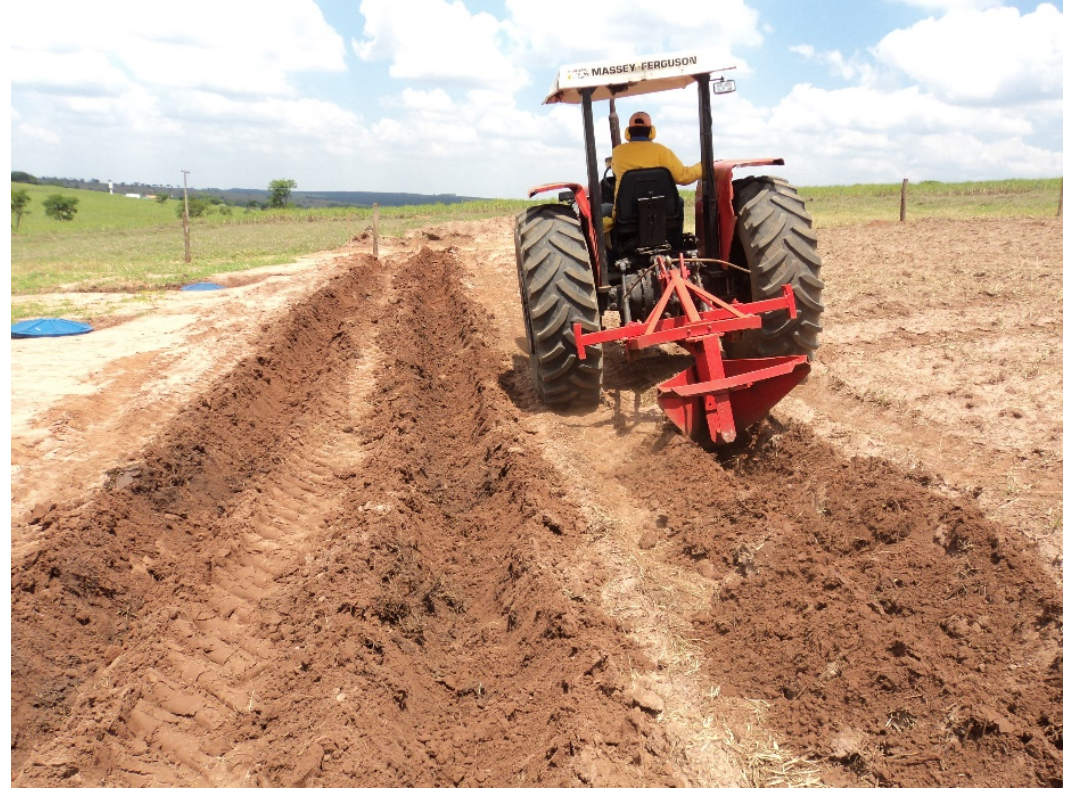


1.3 Adubação de fundo 8-28-25 (N-P-K), $30 \mathrm{~kg}$ (equivalente a 0,6 t.ha-1).

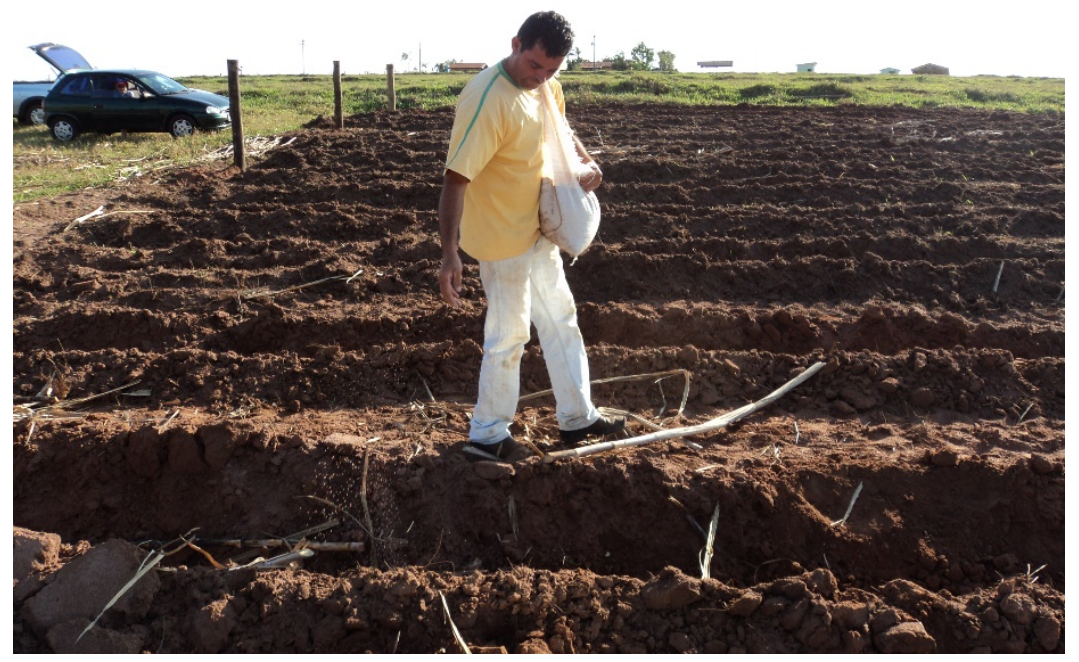

1.4 Plantio de 2 canas por sulco (18 gemas. $\mathrm{m}^{-1}$ ) em sentido inverso (pé com ponta). Uma vez dispostas no sulco, corte com facão e cobrir com solo 5-8 $\mathrm{cm}$. $700 \mathrm{~m}$ lineares de cana (equivalente a $12 \mathrm{t}^{\mathrm{h}} \mathrm{ha}^{-1}$ ). A cana para o projeto foi doada pelo senhor Edgar Nori.

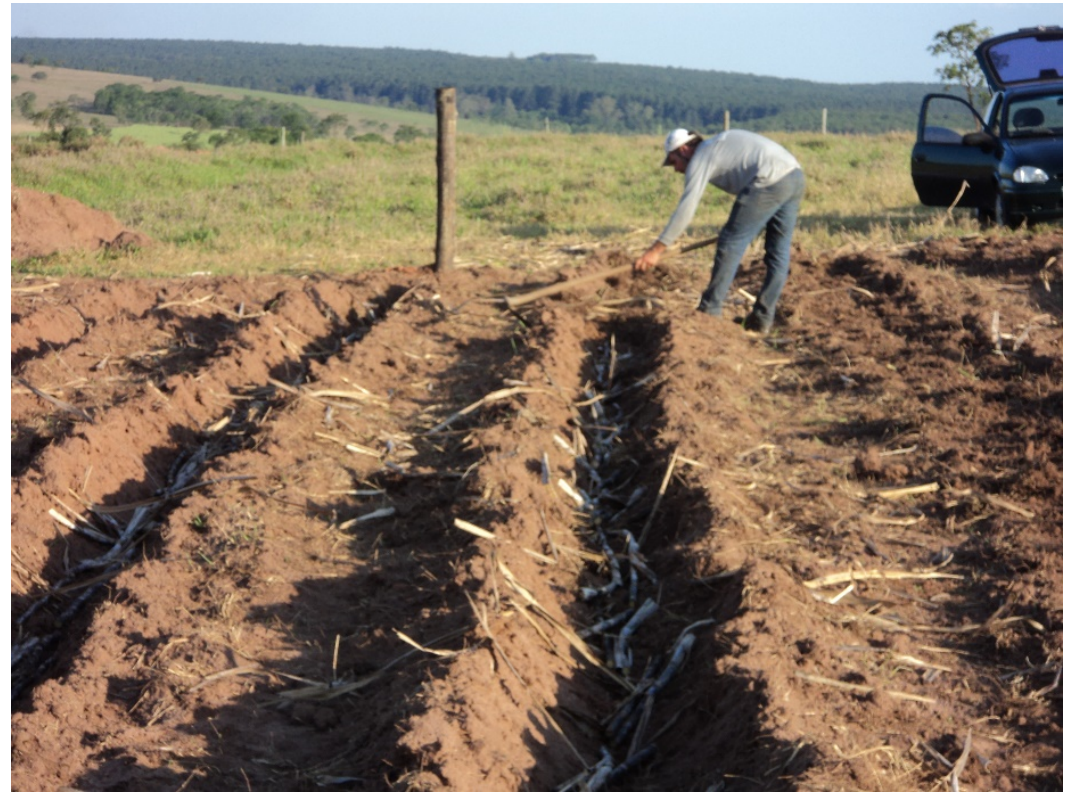

1.5 Corretivo calcário, $100 \mathrm{~kg}$ (equivalente a 2 t.ha-1).

\section{Manutenção}

2.1 Capinagem manual de ervas daninhas, segundo requerido. 


\section{Colheita}

3.1 Corte manual com facão na base do colmo e corte das folhas.

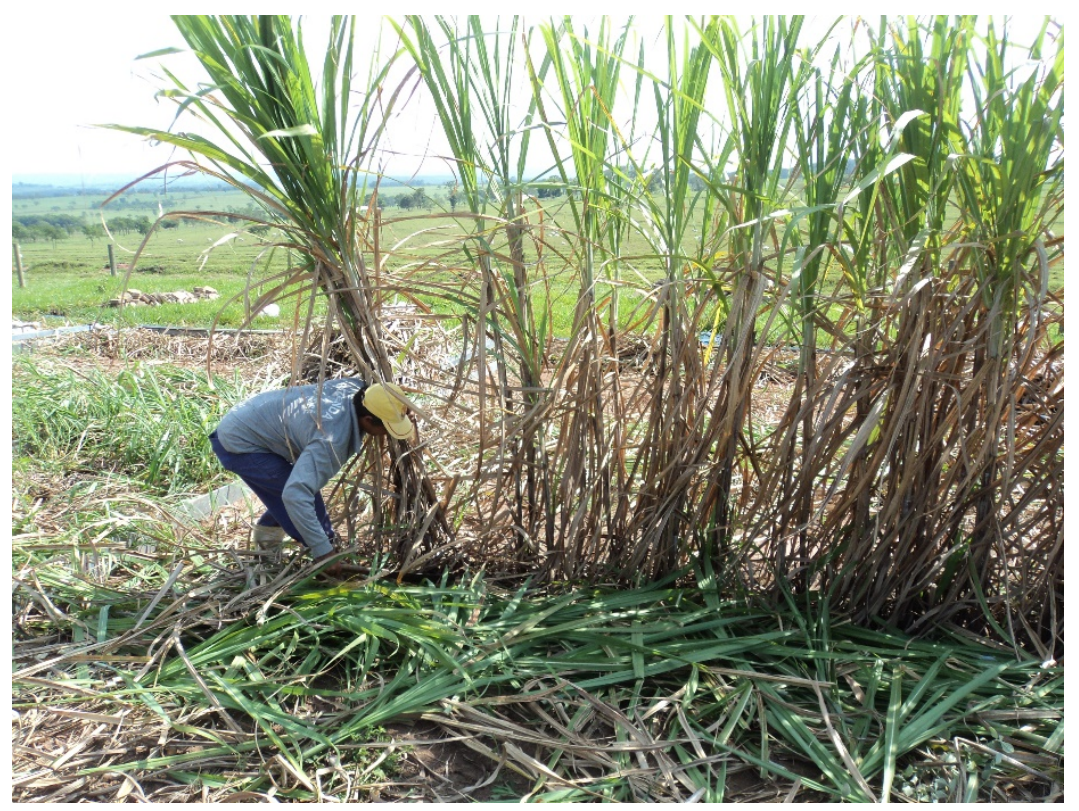

3.2 Dispor a palha a cada três entresulcos (a cada dois entresulcos sem palha, um com palha).

3.3 Gradagem manual do solo nos entresulcos até $20 \mathrm{~cm}$ de profundidade para romper o selamento da superfície.

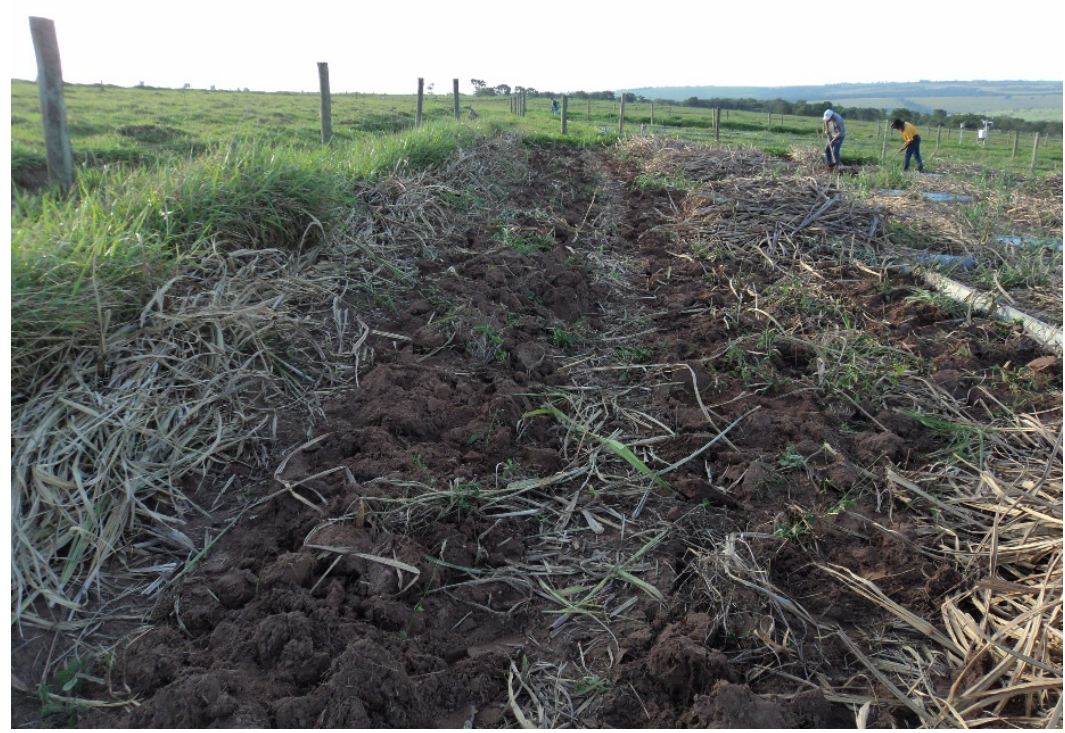

3.4 Adubação de cobertura 18-0-27 (N-P-K) nos dois lados do sulco. $30 \mathrm{~kg}$ (equivalente a 0,6 t.ha-1). 
ANEXO 4

Curva de

Calibração

Altura-Volume para Medição de Caixa D'Água com Escoamento (310 L) 


\begin{tabular}{|c|c|c|c|}
\hline Altura $(\mathrm{cm})$ & Volume (L) & Altura $(\mathrm{cm})$ & Volume (L) \\
\hline 0,0 & 2 & 19,4 & 92 \\
\hline 0,4 & 4 & 19,7 & 94 \\
\hline 1,0 & 6 & 20,2 & 96 \\
\hline 1,4 & 8 & 20,5 & 98 \\
\hline 1,8 & 10 & 20,9 & 100 \\
\hline 2,3 & 12 & 21,3 & 102 \\
\hline 2,8 & 14 & 21,6 & 104 \\
\hline 3,1 & 16 & 22,0 & 106 \\
\hline 3,5 & 18 & 22,4 & 108 \\
\hline 4,0 & 20 & 22,8 & 110 \\
\hline 4,5 & 22 & 23,2 & 112 \\
\hline 5,0 & 24 & 23,6 & 114 \\
\hline 5,4 & 26 & 23,9 & 116 \\
\hline 5,9 & 28 & 24,3 & 118 \\
\hline 6,4 & 30 & 24,6 & 120 \\
\hline 6,9 & 32 & 25,0 & 122 \\
\hline 7,3 & 34 & 25,4 & 124 \\
\hline 7,7 & 36 & 25,7 & 126 \\
\hline 8,1 & 38 & 26,1 & 128 \\
\hline 8,6 & 40 & 26,5 & 130 \\
\hline 9,1 & 42 & 26,8 & 132 \\
\hline 9,5 & 44 & 27,2 & 134 \\
\hline 10,0 & 46 & 27,6 & 136 \\
\hline 10,5 & 48 & 27,9 & 138 \\
\hline 10,9 & 50 & 28,3 & 140 \\
\hline 11,3 & 52 & 28,7 & 142 \\
\hline 11,7 & 54 & 29,0 & 144 \\
\hline 12,2 & 56 & 29,4 & 146 \\
\hline 12,6 & 58 & 29,8 & 148 \\
\hline 13,0 & 60 & 30,1 & 150 \\
\hline 13,5 & 62 & 30,5 & 152 \\
\hline 13,9 & 64 & 30,9 & 154 \\
\hline 14,2 & 66 & 31,3 & 156 \\
\hline 14,7 & 68 & 31,6 & 158 \\
\hline 15,1 & 70 & 31,9 & 160 \\
\hline 15,5 & 72 & 32,3 & 162 \\
\hline 15,9 & 74 & 32,6 & 164 \\
\hline 16,4 & 76 & 33,0 & 166 \\
\hline 16,7 & 78 & 33,3 & 168 \\
\hline 17,1 & 80 & 33,7 & 170 \\
\hline 17,5 & 82 & 34,0 & 172 \\
\hline 17,9 & 84 & 34,4 & 174 \\
\hline 18,2 & 86 & 34,7 & 176 \\
\hline 18,6 & 88 & 35,0 & 178 \\
\hline 19,0 & 90 & 35,4 & 180 \\
\hline
\end{tabular}

Altura $(\mathrm{cm}) \quad$ Volume (L)

35,8 $\quad 182$

$36,1 \quad 184$

$36,5 \quad 186$

$36,8 \quad 188$

$37,1 \quad 190$

$37,4 \quad 192$

$37,8 \quad 194$

$38,1 \quad 196$

$38,4 \quad 198$

$38,8 \quad 200$

$39,1 \quad 202$

$39,5 \quad 204$

$39,8 \quad 206$

$40,1 \quad 208$

$40,4 \quad 210$

$40,7 \quad 212$

$41,1 \quad 214$

$41,4 \quad 216$

$41,8 \quad 218$

$42,0 \quad 220$

$42,4 \quad 222$

$42,7 \quad 224$

$43,0 \quad 226$

$43,3 \quad 228$

$43,6 \quad 230$

$43,9 \quad 232$

$44,2 \quad 234$

$44,5 \quad 236$

$44,8 \quad 238$

$45,1 \quad 240$

$45,4 \quad 242$

$45,7 \quad 244$

$46,0 \quad 246$

$46,3 \quad 248$

$46,5 \quad 250$

$46,8 \quad 252$

$47,1 \quad 254$

$47,4 \quad 256$

$47,7 \quad 258$

$48,0 \quad 260$

\section{Curva altura/volume caixas $310 \mathrm{~L}$}

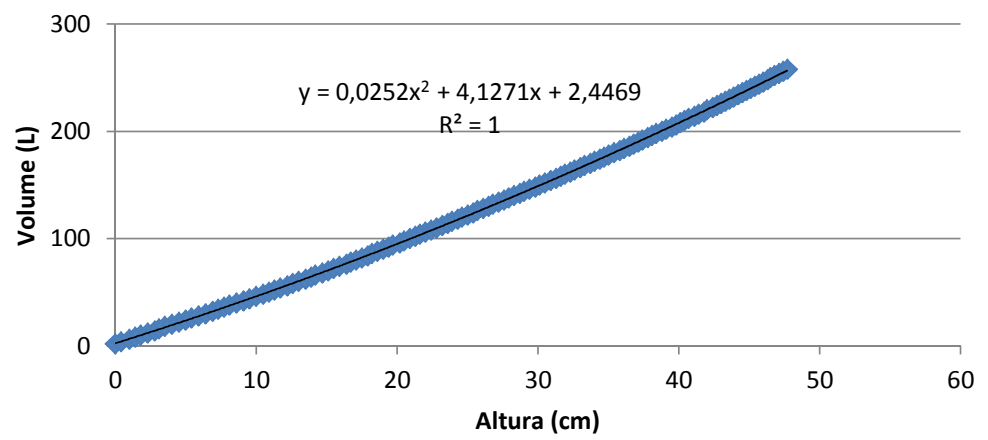


ANEXO 5

Calibração Sensor de Umidade EnviroScan: Coeficientes de Ajuste Segundo Determinação Gravimétrica de Umidade 


\begin{tabular}{|c|c|c|c|c|c|c|c|c|c|c|c|}
\hline $\begin{array}{l}\text { Condição } \\
\text { Profundidade }\end{array}$ & Bequer & $\begin{array}{l}\text { Bequer+ } \\
\text { amostra úmida }\end{array}$ & $\begin{array}{l}\text { Amostra } \\
\text { úmida }\end{array}$ & $\begin{array}{l}\text { Bequer+ } \\
\text { amostra seca }\end{array}$ & $\begin{array}{l}\text { Amostra } \\
\text { seca }\end{array}$ & $\begin{array}{l}\text { Conteúdo } \\
\text { gravimétrico }\end{array}$ & $\begin{array}{l}\text { Densidade } \\
\text { amostra }\end{array}$ & $\begin{array}{l}\text { Conteúdo } \\
\text { volumétrico }\end{array}$ & $\begin{array}{l}\text { Scaled Freq. } \\
\text { medido }\end{array}$ & $\begin{array}{l}\text { Leitura } \\
\text { Sensor }\end{array}$ & $\begin{array}{l}\text { Diferença } \\
\text { Leitura }\end{array}$ \\
\hline Repetição & (g) & (g) & (g) & (g) & (g) & (g) & & (\%) & & (\%) & (\%) \\
\hline Seco 301 & 66,56 & 175,2 & 108,64 & 169,89 & 103,33 & 0,051 & 1,535 & $8 \%$ & 0,541 & $9 \%$ & $-1 \%$ \\
\hline Seco 302 & 66,19 & 173,5 & 107,31 & 168,26 & 102,07 & 0,051 & 1,516 & $8 \%$ & 0,541 & $9 \%$ & $-1 \%$ \\
\hline Seco 303 & 66,69 & 168,61 & 101,92 & 163,6 & 96,91 & 0,052 & 1,440 & $7 \%$ & 0,541 & $9 \%$ & $-2 \%$ \\
\hline Seco 601 & 65,97 & 172,55 & 106,58 & 167,03 & 101,06 & 0,055 & 1,501 & $8 \%$ & 0,512 & $8 \%$ & $0 \%$ \\
\hline Seco 602 & 65,79 & 172,03 & 106,24 & 166,39 & 100,6 & 0,056 & 1,494 & $8 \%$ & 0,512 & $8 \%$ & $0 \%$ \\
\hline Seco 603 & 68,73 & 173,84 & 105,11 & 168,26 & 99,53 & 0,056 & 1,479 & $8 \%$ & 0,512 & $8 \%$ & $0 \%$ \\
\hline Seco 901 & 64,81 & 167,94 & 103,13 & 162,09 & 97,28 & 0,060 & 1,445 & $9 \%$ & 0,501 & $8 \%$ & $1 \%$ \\
\hline Seco 902 & 67,55 & 169,46 & 101,91 & 163,83 & 96,28 & 0,058 & 1,430 & $8 \%$ & 0,501 & $8 \%$ & $1 \%$ \\
\hline Seco 903 & 66,68 & 170,71 & 104,03 & 164,65 & 97,97 & 0,062 & 1,455 & $9 \%$ & 0,501 & $8 \%$ & $1 \%$ \\
\hline Úmido 301 & 66,81 & 190,4 & 123,59 & 176,19 & 109,38 & 0,130 & 1,625 & $21 \%$ & 0,712 & $19 \%$ & $3 \%$ \\
\hline Úmido 302 & 65,35 & 192,72 & 127,37 & 178,3 & 112,95 & 0,128 & 1,678 & $21 \%$ & 0,712 & $19 \%$ & $3 \%$ \\
\hline Úmido 303 & 65,85 & 191,9 & 126,05 & 178,06 & 112,21 & 0,123 & 1,667 & $21 \%$ & 0,712 & $19 \%$ & $2 \%$ \\
\hline Úmido 601 & 66,16 & 181,17 & 115,01 & 168,74 & 102,58 & 0,121 & 1,524 & $18 \%$ & 0,790 & $24 \%$ & $-6 \%$ \\
\hline Úmido 602 & 66,06 & 188,88 & 122,82 & 175,32 & 109,26 & 0,124 & 1,623 & $20 \%$ & 0,790 & $24 \%$ & $-4 \%$ \\
\hline Úmido 603 & 69,4 & 189,01 & 119,61 & 176,02 & 106,62 & 0,122 & 1,584 & $19 \%$ & 0,790 & $24 \%$ & $-5 \%$ \\
\hline Úmido 901 & 65,48 & 183,52 & 118,04 & 170,47 & 104,99 & 0,124 & 1,560 & $19 \%$ & 0,779 & $23 \%$ & $-4 \%$ \\
\hline Úmido 902 & 69,09 & 190,55 & 121,46 & 176,59 & 107,5 & 0,130 & 1,597 & $21 \%$ & 0,779 & $23 \%$ & $-3 \%$ \\
\hline Úmido 903 & 67,38 & 177,8 & 110,42 & 166,33 & 98,95 & 0,116 & 1,470 & $17 \%$ & 0,779 & $23 \%$ & $-6 \%$ \\
\hline Pastagem 30 & 291,72 & 1000,01 & 708,29 & 927,29 & 635,57 & 0,114 & 1,577 & $18 \%$ & 0,690 & $17 \%$ & $1 \%$ \\
\hline Pastagem 60 & 242,76 & 998,25 & 755,49 & 922,22 & 679,46 & 0,112 & 1,534 & $17 \%$ & 0,626 & $13 \%$ & $4 \%$ \\
\hline Pastagem 90 & 230,24 & 1042,2 & 811,96 & 956,6 & 726,36 & 0,118 & 1,493 & $18 \%$ & 0,609 & $12 \%$ & $5 \%$ \\
\hline Cana 30 & 291,7 & 1063,94 & 772,24 & 985,03 & 693,33 & 0,114 & 1,577 & $18 \%$ & 0,707 & $18 \%$ & $0 \%$ \\
\hline Cana 60 & 242,77 & 1038,25 & 795,48 & 959,89 & 717,12 & 0,109 & 1,534 & $17 \%$ & 0,656 & $15 \%$ & $2 \%$ \\
\hline Cana 90 & 230,27 & 1057,91 & 827,64 & 971,75 & 741,48 & 0,116 & 1,493 & $17 \%$ & 0,664 & $15 \%$ & $2 \%$ \\
\hline
\end{tabular}

Calibração Scaled Frequency

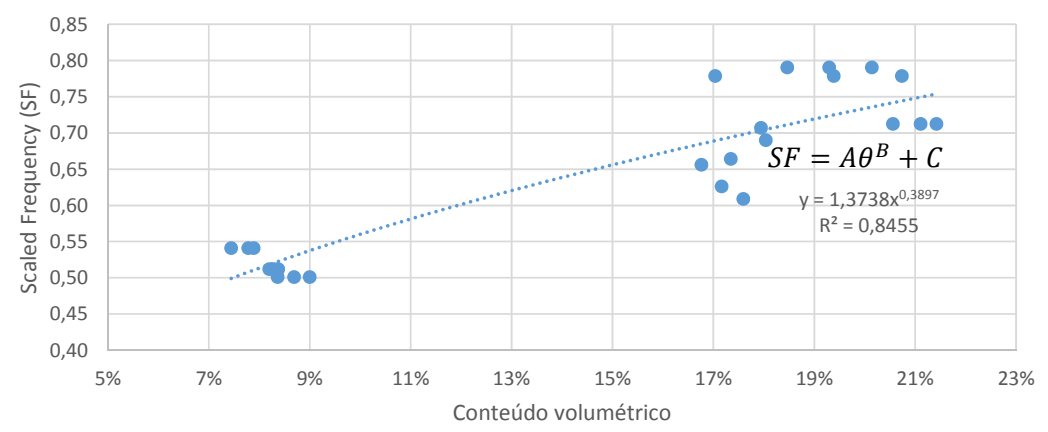

Umidade real v/s leitura sensor

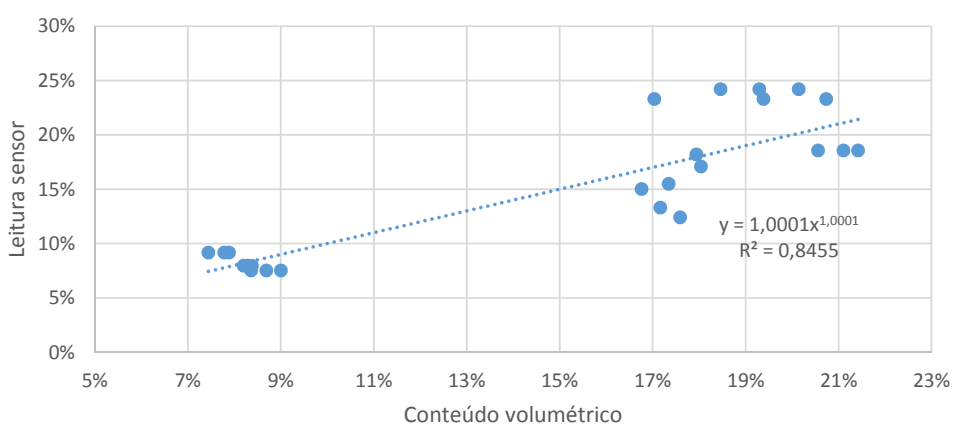


Dados de Erosão e Escoamento, por Parcela e

Evento de Precipitação 


\begin{tabular}{|c|c|c|c|c|c|c|c|c|c|c|c|}
\hline \multirow{2}{*}{ Data } & \multirow{2}{*}{ PP } & \multirow{2}{*}{ Parcela } & \multirow{2}{*}{\begin{tabular}{|l} 
Pastagem \\
Escoamento \\
\end{tabular}} & \multirow{2}{*}{$\begin{array}{c}\text { Mm) } \\
\text { Media }\end{array}$} & \multirow[b]{2}{*}{ Desvio } & \multirow{2}{*}{\begin{tabular}{|c|}
$\begin{array}{c}\text { Cana-de-açúcar } \\
\text { Escoamento }\end{array}$ \\
\end{tabular}} & \multicolumn{3}{|c|}{$(\mathrm{mm})$} & \multirow{2}{*}{ Media } & \multirow[b]{2}{*}{ Desvio } \\
\hline & & & & & & & Media & Desvio & Interceptação & & \\
\hline $14 / 11 / 2011$ & \multirow{3}{*}{30,8} & 1 & 1,67 & \multirow{3}{*}{2,53} & \multirow{3}{*}{1,75} & $\overline{0,41}$ & \multirow{3}{*}{0,32} & \multirow{3}{*}{0,10} & 0,00 & \multirow{3}{*}{0,00} & \multirow{3}{*}{0,00} \\
\hline $14 / 11 / 2011$ & & 2 & 1,38 & & & 0,35 & & & 0,00 & & \\
\hline $14 / 11 / 2011$ & & 3 & 4,55 & & & 0,21 & & & 0,00 & & \\
\hline $15 / 11 / 2011$ & \multirow{3}{*}{35,2} & 1 & 4,62 & & & 0,37 & & & 0,00 & & \\
\hline 15/11/2011 & & 2 & 1,77 & 3,64 & 1,62 & 0,33 & 0,31 & 0,08 & 0,00 & 0,00 & 0,00 \\
\hline $15 / 11 / 2011$ & & 3 & 4,55 & & & 0,22 & & & 0,00 & & \\
\hline $22 / 11 / 2011$ & & 1 & 0,00 & & & 0,09 & & & 0,00 & & \\
\hline $22 / 11 / 2011$ & 10,2 & 2 & 0,00 & 0,00 & 0,00 & 0,08 & 0,07 & 0,02 & 0,00 & 0,00 & 0,00 \\
\hline $22 / 11 / 2011$ & & 3 & 0,00 & & & 0,04 & & & 0,00 & & \\
\hline $27 / 11 / 2011$ & & 1 & 0,00 & & & 0,05 & & & 0,00 & & \\
\hline 27/11/2011 & 15,8 & 2 & 0,01 & 0,01 & 0,02 & 0,02 & 0,03 & 0,02 & 0,00 & 0,00 & 0,00 \\
\hline 27/11/2011 & & 3 & 0,03 & & & 0,03 & & & 0,00 & & \\
\hline 30/11/2011 & & 1 & 0,00 & & & 0,05 & & & 0,00 & & \\
\hline 30/11/2011 & 7,2 & 2 & 0,00 & 0,02 & 0,03 & 0,08 & 0,05 & 0,03 & 0,00 & 0,00 & 0,00 \\
\hline 30/11/2011 & & 3 & 0,06 & & & 0,03 & & & 0,00 & & \\
\hline $06 / 12 / 2011$ & & 1 & 0,00 & & & 0,10 & & & 0,00 & & \\
\hline $06 / 12 / 2011$ & 6,4 & 2 & 0,03 & 0,02 & 0,02 & 0,04 & 0,06 & 0,04 & 0,00 & 0,00 & 0,00 \\
\hline $06 / 12 / 2011$ & & 3 & 0,02 & & & 0,04 & & & 0,00 & & \\
\hline $08 / 12 / 2011$ & & 1 & 0,00 & & & 0,16 & & & 0,00 & & \\
\hline $08 / 12 / 2011$ & 23 & 2 & 0,03 & 0,02 & 0,02 & 0,09 & 0,10 & 0,06 & 0,00 & 0,00 & 0,00 \\
\hline $08 / 12 / 2011$ & & 3 & 0,04 & & & 0,05 & & & 0,00 & & \\
\hline 10/12/2011 & & 1 & 17,57 & & & 13,21 & & & 0,00 & & \\
\hline 10/12/2011 & 101,4 & 2 & 3,25 & 8,03 & 8,26 & 11,24 & 10,26 & 3,55 & 0,00 & 0,00 & 0,00 \\
\hline $10 / 12 / 2011$ & & 3 & 3,27 & & & 6,32 & & & 0,00 & & \\
\hline $22 / 12 / 2011$ & & 1 & 0,00 & & & 0,07 & & & 0,00 & & \\
\hline $22 / 12 / 2011$ & 10,8 & 2 & 0,00 & 0,01 & 0,00 & 0,04 & 0,05 & 0,02 & 0,00 & 0,00 & 0,00 \\
\hline $22 / 12 / 2011$ & & 3 & 0,01 & & & 0,03 & & & 0,00 & & \\
\hline $24 / 12 / 2011$ & & 1 & 0,06 & & & 1,36 & & & 0,00 & & \\
\hline 24/12/2011 & 27,6 & 2 & 0,02 & 0,04 & 0,02 & 1,02 & 1,05 & 0,30 & 0,00 & 0,00 & 0,00 \\
\hline $24 / 12 / 2011$ & & 3 & 0,05 & & & 0,77 & & & 0,00 & & \\
\hline $01 / 01 / 2012$ & & 1 & 0,14 & & & 1,34 & & & 0,00 & & \\
\hline $01 / 01 / 2012$ & 53,8 & 2 & 0,04 & 0,07 & 0,06 & 0,93 & 0,90 & 0,46 & 0,00 & 0,00 & 0,00 \\
\hline $01 / 01 / 2012$ & & 3 & 0,04 & & & 0,42 & & & 0,00 & & \\
\hline $05 / 01 / 2012$ & & 1 & 0,00 & & & 0,14 & & & 0,00 & & \\
\hline $05 / 01 / 2012$ & 7,4 & 2 & 0,00 & 0,00 & 0,00 & 0,06 & 0,07 & 0,05 & 0,00 & 0,00 & 0,00 \\
\hline $05 / 01 / 2012$ & & 3 & 0,00 & & & 0,03 & & & 0,00 & & \\
\hline $08 / 01 / 2012$ & & 1 & 0,00 & & & 0,36 & & & 0,00 & & \\
\hline $08 / 01 / 2012$ & 10,4 & 2 & 0,00 & 0,01 & 0,02 & 0,25 & 0,24 & 0,12 & 0,00 & 0,00 & 0,00 \\
\hline $08 / 01 / 2012$ & & 3 & 0,04 & & & 0,12 & & & 0,00 & & \\
\hline $11 / 01 / 2012$ & & 1 & 0,20 & & & 0,99 & & & 0,00 & & \\
\hline $11 / 01 / 2012$ & 32,2 & 2 & 0,02 & 0,09 & 0,10 & 0,71 & 0,75 & 0,22 & 0,00 & 0,00 & 0,00 \\
\hline $11 / 01 / 2012$ & & 3 & 0,04 & & & 0,56 & & & 0,00 & & \\
\hline $16 / 01 / 2012$ & & 1 & 0,01 & & & 0,06 & & & 0,00 & & \\
\hline $16 / 01 / 2012$ & 9,8 & 2 & 0,00 & 0,01 & 0,00 & 0,03 & 0,03 & 0,02 & 0,00 & 0,00 & 0,00 \\
\hline $16 / 01 / 2012$ & & 3 & 0,01 & & & 0,02 & & & 0,00 & & \\
\hline $17 / 01 / 2012$ & & 1 & $0,0,91$ & & & 1,88 & & & 0,42 & & \\
\hline $17 / 01 / 2012$ & 17,6 & 2 & 0,20 & 0,56 & 0,40 & 1,37 & 1,59 & 0,26 & 0,93 & 0,46 & 0,45 \\
\hline $17 / 01 / 2012$ & & 3 & 0,49 & & & 1,51 & & & 0,04 & & \\
\hline
\end{tabular}




\begin{tabular}{|c|c|c|c|c|c|c|c|c|c|c|c|}
\hline \multirow{2}{*}{ Data } & \multirow{2}{*}{ PP } & \multirow{2}{*}{ Parcela } & \multirow{2}{*}{\begin{tabular}{|l|} 
Pastagem \\
Escoamento
\end{tabular}} & \multirow{2}{*}{$\begin{array}{l}(\mathrm{mm}) \\
\text { Media }\end{array}$} & \multirow[b]{2}{*}{ Desvio } & \multirow{2}{*}{$\begin{array}{l}\text { Cana-de-açúcar } \\
\text { Escoamento }\end{array}$} & \multicolumn{2}{|c|}{$(\mathrm{mm})$} & \multirow[b]{2}{*}{ Interceptação } & \multirow{2}{*}{ Media } & \multirow[b]{2}{*}{ Desvio } \\
\hline & & & & & & & Media & Desvio & & & \\
\hline $18 / 01 / 2012$ & & 1 & $\begin{array}{ll}0,19 \\
\end{array}$ & & & 0,84 & & & 2,13 & & \\
\hline $18 / 01 / 2012$ & 18,8 & 2 & 0,02 & 0,08 & 0,10 & 0,63 & 0,68 & 0,14 & 3,42 & 2,73 & 0,65 \\
\hline $18 / 01 / 2012$ & & 3 & 0,03 & & & 0,56 & & & 2,65 & & \\
\hline $19 / 01 / 2012$ & & 1 & 3,46 & & & 6,31 & & & 2,38 & & \\
\hline $19 / 01 / 2012$ & 17 & 2 & 2,87 & 3,21 & 0,30 & 5,97 & 6,19 & 0,19 & 4,18 & 3,24 & 0,90 \\
\hline $19 / 01 / 2012$ & & 3 & 3,30 & & & 6,30 & & & 3,15 & & \\
\hline $20 / 01 / 2012$ & & 1 & 0,00 & & & 0,34 & & & 0,94 & & \\
\hline $20 / 01 / 2012$ & 11,2 & 2 & 0,00 & 0,00 & 0,00 & 0,23 & 0,23 & 0,11 & 2,48 & 1,71 & 0,77 \\
\hline 20/01/2012 & & 3 & 0,00 & & & 0,12 & & & 1.71 & & \\
\hline $21 / 01 / 2012$ & & 1 & 0,02 & & & 0,15 & & & 0,24 & & \\
\hline $21 / 01 / 2012$ & 12,8 & 2 & 0,00 & 0,01 & 0,01 & 0,09 & 0,09 & 0,05 & 0,24 & 0,24 & 0,00 \\
\hline $21 / 01 / 2012$ & & 3 & 0,00 & & & 0,04 & & & 0,24 & & \\
\hline $22 / 01 / 2012$ & & 1 & 4,43 & & & 6,82 & & & 0,45 & & \\
\hline $22 / 01 / 2012$ & 16,6 & 2 & 3,46 & 4,03 & 0,51 & 6,62 & 6,21 & 0,89 & 0,19 & 0,28 & 0,15 \\
\hline $22 / 01 / 2012$ & & 3 & 4,20 & & & 5,19 & & & 0,19 & & \\
\hline $26 / 01 / 2012$ & & 1 & 0,00 & & & 0,07 & & & 1,38 & & \\
\hline $26 / 01 / 2012$ & 6 & 2 & 0,02 & 0,01 & 0,01 & 0,03 & 0,04 & 0,02 & 1,38 & 1,21 & 0,30 \\
\hline $26 / 01 / 2012$ & & 3 & 0,01 & & & 0,03 & & & 0,87 & & \\
\hline $26 / 01 / 2012$ & & 1 & 0,00 & & & 0,27 & & & 0,23 & & \\
\hline $26 / 01 / 2012$ & 9,2 & 2 & 0,00 & 0,00 & 0,00 & 0,17 & 0,17 & 0,10 & 1,51 & 0,99 & 0,68 \\
\hline $26 / 01 / 2012$ & & 3 & 0,00 & & & 0,08 & & & 1,25 & & \\
\hline $28 / 01 / 2012$ & & 1 & 0,97 & & & 1,24 & & & 0,49 & & \\
\hline $28 / 01 / 2012$ & 21 & 2 & 0,11 & 0,46 & 0,45 & 0,77 & 0,73 & 0,53 & 3,05 & 1,34 & 1,48 \\
\hline $28 / 01 / 2012$ & & 3 & 0,31 & & & 0,18 & & & 0,49 & & \\
\hline $11 / 02 / 2012$ & & 1 & 1,23 & & & 1,72 & & & 0,22 & & \\
\hline $11 / 02 / 2012$ & 25,6 & 2 & 0,74 & 1,03 & 0,26 & 1,31 & 1,12 & 0,71 & 5,09 & 2,35 & 2,49 \\
\hline $11 / 02 / 2012$ & & 3 & 1.13 & & & 0,33 & & & 175 & & \\
\hline $12 / 02 / 2012$ & & 1 & 2,15 & & & 2,42 & & & 2,75 & & \\
\hline $12 / 02 / 2012$ & 34,8 & 2 & 1,23 & 1,58 & 0,50 & 1,91 & 2,05 & 0,33 & 1,47 & 1,89 & 0,74 \\
\hline $12 / 02 / 2012$ & & 3 & 1,35 & & & 1,80 & & & 1,47 & & \\
\hline $19 / 02 / 2012$ & & 1 & 0,01 & & & 0,29 & & & 2,42 & & \\
\hline $19 / 02 / 2012$ & 8,8 & 2 & 0,02 & 0,02 & 0,01 & 0,13 & 0,24 & 0,09 & 1,85 & 2,23 & 0,33 \\
\hline $19 / 02 / 2012$ & & 3 & 0,03 & & & 0,29 & & & 2,42 & & \\
\hline $24 / 02 / 2012$ & & 1 & 8,65 & & & 12,84 & & & 4,35 & & \\
\hline $23 / 02 / 2012$ & 51,4 & 2 & 5,97 & 7,59 & 1,42 & 11,19 & 12,54 & 1,23 & 8,71 & 5,59 & 2,72 \\
\hline $24 / 02 / 2012$ & & 3 & 8,13 & & & 13,60 & & & 3,71 & & \\
\hline $27 / 02 / 2012$ & & 1 & 1,93 & & & 3,63 & & & 4,43 & & \\
\hline $27 / 02 / 2012$ & 28,4 & 2 & 0,79 & 1,23 & 0,61 & 2,81 & 3,31 & 0,44 & 7,12 & 5,52 & 1,42 \\
\hline $27 / 02 / 2012$ & & 3 & 0,97 & & & 3,49 & & & 5,02 & & \\
\hline $01 / 03 / 2012$ & & 1 & 0,02 & & & 0,57 & & & 4,72 & & \\
\hline $01 / 03 / 2012$ & 17,8 & 2 & 0,02 & 0,02 & 0,00 & 0,36 & 0,34 & 0,24 & 7,54 & 5,96 & 1.44 \\
\hline $01 / 03 / 2012$ & & 3 & 0,02 & & & 0,10 & & & 5,62 & & \\
\hline $03 / 03 / 2012$ & & $\frac{3}{1}$ & 0,01 & & & 0,04 & & & $\frac{1,02}{3,70}$ & & \\
\hline $03 / 03 / 2012$ & 12,8 & 2 & 0,01 & 0,01 & 0,00 & 0,01 & 0,02 & 0,02 & 4,79 & 3,68 & 1,12 \\
\hline $03 / 03 / 2012$ & & 3 & 0,01 & & & 0,01 & & & 2,54 & & \\
\hline $15 / 03 / 2012$ & & 1 & 0,00 & & & 0,01 & & & 3,97 & & \\
\hline $15 / 03 / 2012$ & 8,2 & 2 & 0,00 & 0,00 & 0,00 & 0,02 & 0,01 & 0,01 & 4,05 & 3,42 & 1,01 \\
\hline $15 / 03 / 2012$ & & 3 & 0,00 & & & 0,01 & & & 2,25 & & \\
\hline $09 / 04 / 2012$ & & 1 & 0,00 & & & 0,01 & & & 4,14 & & \\
\hline $09 / 04 / 2012$ & 9,4 & 2 & 0,00 & 0,00 & 0,00 & 0,00 & 0,00 & 0,00 & 5,17 & 4,10 & 1,09 \\
\hline $09 / 04 / 2012$ & & 3 & 0,00 & & & 0,00 & & & 2,99 & & \\
\hline
\end{tabular}




\begin{tabular}{|c|c|c|c|c|c|c|c|c|c|c|c|}
\hline Data & PP & Parcela & Pastagem & (mm) & Docvio & Cana-de-açúcar & & (mm) & & & \\
\hline $21 / 04 / 2012$ & \multirow{3}{*}{31,8} & & Escoamento & Media & \multirow{3}{*}{0,39} & Escoamento & Media & Desvio & Interceptação & Media & Desvio \\
\hline $\begin{array}{l}21 / 04 / 2012 \\
21 / 04 / 2012\end{array}$ & & 1 & 1,94 & \multirow{2}{*}{1,77} & & 1,25 & \multirow{2}{*}{0,92} & \multirow{2}{*}{0,31} & 13,66 & \multirow{2}{*}{11,86} & \multirow{2}{*}{3,28} \\
\hline $21 / 04 / 2012$ & & 3 & 2,03 & & & $\begin{array}{l}0,64 \\
0,87\end{array}$ & & & $\begin{array}{l}13,85 \\
8,08\end{array}$ & & \\
\hline $26 / 04 / 2012$ & \multirow{3}{*}{11,8} & 1 & 0,00 & \multirow{3}{*}{0,00} & \multirow{3}{*}{0,00} & 0,09 & \multirow{3}{*}{0,04} & \multirow{3}{*}{0,04} & 5,77 & \multirow{3}{*}{6,56} & \multirow{3}{*}{0,74} \\
\hline $26 / 04 / 2012$ & & 2 & 0,00 & & & 0,01 & & & 6,67 & & \\
\hline $26 / 04 / 2012$ & & 3 & 0,00 & & & 0,02 & & & 7,24 & & \\
\hline $30 / 04 / 2012$ & \multirow{3}{*}{65,2} & 1 & 0,02 & \multirow{3}{*}{0,04} & \multirow{3}{*}{0,02} & 0,52 & \multirow{3}{*}{0,24} & \multirow{3}{*}{0,25} & 33,15 & & \\
\hline $30 / 04 / 2012$ & & 2 & 0,04 & & & 0,12 & & & 35,33 & 28,06 & 10,75 \\
\hline $30 / 04 / 2012$ & & 3 & 0,06 & & & 0,07 & & & 15,71 & & \\
\hline $14 / 05 / 2012$ & & 1 & 0,00 & & & 0,12 & & & 20,44 & & \\
\hline $14 / 05 / 2012$ & 43 & 2 & 0,04 & 0,03 & 0,03 & 0,02 & 0,06 & 0,05 & 23,90 & 20,86 & 2,84 \\
\hline $14 / 05 / 2012$ & & 3 & 0,06 & & & 0,03 & & & 18,26 & & \\
\hline $08 / 06 / 2012$ & & 1 & 0,69 & & & 1,75 & & & 23,96 & & \\
\hline 08/06/2012 & 47,6 & 2 & 0,18 & 0,41 & 0,26 & 0,94 & 1,10 & 0,58 & 21,83 & 21,04 & 3,38 \\
\hline 08/06/2012 & & 3 & 0,36 & & & 0,62 & & & 17,34 & & \\
\hline $22 / 06 / 2012$ & & 1 & 0,27 & & & 0,61 & & & 32,77 & & \\
\hline $22 / 06 / 2012$ & 73,8 & 2 & 0,08 & 0,16 & 0,10 & 0,11 & 0,26 & 0,30 & 36,93 & 32,02 & 5,32 \\
\hline $22 / 06 / 2012$ & & 3 & 0,13 & & & 0,06 & & & 26,36 & & \\
\hline $17 / 07 / 2012$ & & 1 & 0,05 & & & 0,28 & & & 6,73 & & \\
\hline $17 / 07 / 2012$ & 16,6 & 2 & 0,02 & 0,03 & 0,02 & 0,02 & 0,10 & 0,15 & 7,11 & 8,39 & 2,56 \\
\hline $17 / 07 / 2012$ & & 3 & 0,02 & & & 0,01 & & & 11,34 & & 2,00 \\
\hline $21 / 09 / 2012$ & & 1 & 0,16 & & & 0,21 & & & 11,95 & & \\
\hline $21 / 09 / 2012$ & 45,8 & 2 & 0,14 & 0,20 & 0,09 & 0,03 & 0,08 & 0,11 & 13,75 & 13,58 & 1,55 \\
\hline $21 / 09 / 2012$ & & 3 & 0,31 & & & 0,02 & & & 15,03 & & \\
\hline $25 / 09 / 2012$ & & 1 & 0,93 & & & 1,09 & & & 4,20 & & \\
\hline $25 / 09 / 2012$ & 19,2 & 2 & 0,31 & 0,58 & 0,32 & 0,39 & 0,58 & 0,45 & 10,23 & 7,16 & 3,01 \\
\hline $25 / 09 / 2012$ & & 3 & 0,49 & & & 0,26 & & & 7,05 & & \\
\hline $24 / 10 / 2012$ & & 1 & 0,02 & & & 0,22 & & & 13,86 & & \\
\hline $24 / 10 / 2012$ & 33,6 & 2 & 0,07 & 0,04 & 0,03 & 0,06 & 0,10 & 0,10 & 10,91 & 12,38 & 1,47 \\
\hline $24 / 10 / 2012$ & & 3 & 0,04 & & & 0,03 & & & 12,37 & & \\
\hline $25 / 10 / 2012$ & & 1 & 3,84 & & & 3,93 & & & 7,32 & & \\
\hline $25 / 10 / 2012$ & 27,4 & 2 & 2,12 & 2,91 & 0,87 & 1,81 & 2,80 & 1,07 & 12,40 & 8,02 & 4,08 \\
\hline $25 / 10 / 2012$ & & 3 & 2,77 & & & 2,65 & & & 4,32 & & \\
\hline $09 / 11 / 2012$ & & 1 & 0,13 & & & 0,04 & & & 0,00 & & \\
\hline 09/11/2012 & 33,2 & 2 & 0,04 & 0,07 & 0,05 & 0,02 & 0,02 & 0,01 & 0,00 & 0,00 & 0,00 \\
\hline $09 / 11 / 2012$ & & 3 & 0,04 & & & 0,02 & & & 0,00 & & \\
\hline $03 / 12 / 2012$ & & 1 & 0,38 & & & 0,45 & & & 0,00 & & \\
\hline $03 / 12 / 2012$ & 38,4 & 2 & 0,13 & 0,21 & 0,15 & 0,25 & 0,27 & 0,18 & 0,00 & 0,00 & 0,00 \\
\hline $03 / 12 / 2012$ & & 3 & 0,12 & & & 0,10 & & & 0,00 & & \\
\hline $10 / 12 / 2012$ & & 1 & 0,01 & & & 0,09 & & & 0,00 & & \\
\hline $10 / 12 / 2012$ & 12,8 & 2 & 0,02 & 0,01 & 0,01 & 0,06 & 0,06 & 0,04 & 0,00 & 0,00 & 0,00 \\
\hline $10 / 12 / 2012$ & & 3 & 0,01 & & & 0,02 & & & 0,00 & & \\
\hline $13 / 12 / 2012$ & & 1 & 0,01 & & & 0,01 & & & 0,00 & & \\
\hline $13 / 12 / 2012$ & 19,4 & 2 & 0,01 & 0,01 & 0,00 & 0,03 & 0,05 & 0,06 & 0,00 & 0,00 & 0,00 \\
\hline $13 / 12 / 2012$ & & 3 & 0,01 & & & 0,12 & & & 0,00 & & \\
\hline $13 / 12 / 2012$ & & $\frac{5}{1}$ & 0,01 & & & $0, \frac{112}{0,11}$ & & & 0,00 & & \\
\hline $13 / 12 / 2012$ & 14,8 & 2 & 0,01 & 0,01 & 0,00 & 0,02 & 0,05 & 0,06 & 0,00 & 0,00 & 0,00 \\
\hline $13 / 12 / 2012$ & & 3 & 0.01 & & & 0.01 & & & 000 & & \\
\hline
\end{tabular}




\begin{tabular}{|c|c|c|c|c|c|c|c|c|c|c|c|}
\hline \multirow{2}{*}{ Data } & \multirow{2}{*}{ PP } & \multirow{2}{*}{ Parcela } & \multirow{2}{*}{\begin{tabular}{|l|} 
Pastagem \\
Escoamento
\end{tabular}} & \multirow{2}{*}{$\begin{array}{c}(\mathrm{mm}) \\
\text { Media }\end{array}$} & \multirow[b]{2}{*}{ Desvio } & \multirow{2}{*}{\begin{tabular}{|c|} 
Cana-de-açúcar \\
Escoamento
\end{tabular}} & \multicolumn{2}{|c|}{ (mm) } & \multirow[b]{2}{*}{ Interceptação } & \multirow[b]{2}{*}{ Media } & \multirow[b]{2}{*}{ Desvic } \\
\hline & & & & & & & Media & Desvio & & & \\
\hline $17 / 12 / 2012$ & & 1 & 0,03 & & & 0,71 & & & 0,00 & & \\
\hline $17 / 12 / 2012$ & 60,8 & 2 & 0,04 & 0,03 & 0,00 & 0,30 & 0,37 & 0,31 & 0,00 & 0,00 & 0,00 \\
\hline $17 / 12 / 2012$ & & 3 & 0,03 & & & 0,09 & & & 0,00 & & \\
\hline $28 / 12 / 2012$ & & 1 & 4,70 & & & 3,49 & & & 0,00 & & \\
\hline $28 / 12 / 2012$ & 38,2 & 2 & 2,47 & 3,92 & 1,26 & 2,00 & 2,43 & 0,92 & 0,00 & 0,00 & 0,00 \\
\hline $28 / 12 / 2012$ & & 3 & 4,60 & & & 1,81 & & & 0,00 & & \\
\hline $13 / 01 / 2013$ & & 1 & 3,80 & & & 3,58 & & & 42,32 & & \\
\hline $13 / 01 / 2013$ & 93,6 & 2 & 2,27 & 3,91 & 1,70 & 1,43 & 2,07 & 1,31 & 39,75 & 39,75 & 2,56 \\
\hline $13 / 01 / 2013$ & & 3 & 5,66 & & & 1,20 & & & 37,19 & & \\
\hline $15 / 01 / 2013$ & & 1 & 0,97 & & & 1,25 & & & 7,73 & & \\
\hline $15 / 01 / 2013$ & 22,6 & 2 & 0,25 & 0,58 & 0,36 & 0,58 & 0,74 & 0,46 & 5,57 & 4,96 & 3,12 \\
\hline $15 / 01 / 2013$ & & 3 & 0,53 & & & 0,38 & & & 1,57 & & \\
\hline $17 / 01 / 2013$ & & 1 & 0,02 & & & 0,08 & & & 6,18 & & \\
\hline $17 / 01 / 2013$ & 20,6 & 2 & 0,02 & 0,01 & 0,00 & 0,06 & 0,05 & 0,03 & 4,83 & 4,13 & 2,48 \\
\hline $17 / 01 / 2013$ & & 3 & 0,01 & & & 0,02 & & & 1,37 & & \\
\hline $23 / 01 / 2013$ & & 1 & 0,00 & & & 0,03 & & & 2,59 & & \\
\hline $23 / 01 / 2013$ & 9 & 2 & 0,00 & 0,00 & 0,00 & 0,00 & 0,01 & 0,01 & 9,00 & 6,86 & 3,70 \\
\hline $23 / 01 / 2013$ & & 3 & 0,00 & & & 0,00 & & & 9,00 & & \\
\hline $04 / 02 / 2013$ & & 1 & 0,01 & & & 0,05 & & & 0,48 & & \\
\hline 04/02/2013 & 17,4 & 2 & 0,01 & 0,01 & 0,00 & 0,02 & 0,03 & 0,02 & 1,19 & 0,77 & 0,38 \\
\hline $04 / 02 / 2013$ & & 3 & 0,01 & & & 0,02 & & & 0,63 & & \\
\hline $06 / 02 / 2013$ & & 1 & 5,19 & & & 2,34 & & & 11,60 & & \\
\hline $06 / 02 / 2013$ & 26,6 & 2 & 2,48 & 4,30 & 1,58 & 1,50 & 1,70 & 0,57 & 12,50 & 11,62 & 0,87 \\
\hline $06 / 02 / 2013$ & & 3 & 5,24 & & & 1,24 & & & 10,75 & & \\
\hline $09 / 02 / 2013$ & & 1 & 0,12 & & & 0,02 & & & 2,48 & & \\
\hline 09/02/2013 & 11,2 & 2 & 0,03 & 0,07 & 0,05 & 0,02 & 0,07 & 0,08 & 2,61 & 2,76 & 0,37 \\
\hline 09/02/2013 & & 3 & 0,05 & & & 0,16 & & & 3,17 & & \\
\hline $27 / 02 / 2013$ & & 1 & 0,07 & & & 0,02 & & & 4,99 & & \\
\hline $27 / 02 / 2013$ & 11,4 & 2 & 0,02 & 0,08 & 0,06 & 0,00 & 0,01 & 0,01 & 5,25 & 5,08 & 0,15 \\
\hline $27 / 02 / 2013$ & & 3 & 0,14 & & & 0,00 & & & 4,99 & & \\
\hline $04 / 03 / 2013$ & & 1 & 0,34 & & & 0,05 & & & 4,10 & & \\
\hline $04 / 03 / 2013$ & 13,2 & 2 & 0,09 & 0,27 & 0,16 & 0,00 & 0,02 & 0,03 & 3,79 & 3,74 & 0,39 \\
\hline $04 / 03 / 2013$ & & 3 & 0,37 & & & 0,01 & & & 3,33 & & \\
\hline $11 / 03 / 2013$ & & 1 & 0,90 & & & 0,10 & & & 16,59 & & \\
\hline $11 / 03 / 2013$ & 30 & 2 & 0,32 & 0,66 & 0,30 & 0,00 & 0,03 & 0,06 & 17,87 & 17,82 & 1,21 \\
\hline $11 / 03 / 2013$ & & 3 & 0,75 & & & 0,00 & & & 19,00 & & \\
\hline $12 / 03 / 2013$ & & 1 & 9,91 & & & 3,88 & & & 12,02 & & \\
\hline $12 / 03 / 2013$ & 27,4 & 2 & 7,91 & 10,34 & 2,67 & 2,30 & 3,09 & 0,79 & 12,02 & 12,14 & 0,22 \\
\hline $12 / 03 / 2013$ & & 3 & 13,19 & & & 3,11 & & & 12,40 & & \\
\hline $13 / 03 / 2013$ & & 1 & 1,19 & & & 0,14 & & & 6,51 & & \\
\hline $13 / 03 / 2013$ & 14,2 & 2 & 0,43 & 0,85 & 0,39 & 0,03 & 0,06 & 0,07 & 7,53 & 7,46 & 0,92 \\
\hline $13 / 03 / 2013$ & & 3 & 0,93 & & & 0,01 & & & 8,35 & & \\
\hline $21 / 03 / 2013$ & & 1 & 0,00 & & & 0,03 & & & 14,62 & & \\
\hline $21 / 03 / 2013$ & 21,8 & 2 & 0,03 & 0,01 & 0,02 & 0,00 & 0,01 & 0,02 & 15,13 & 14,62 & 0,51 \\
\hline $21 / 03 / 2013$ & & 3 & 0,00 & & & 0,00 & & & 14,11 & & \\
\hline $03 / 04 / 2013$ & & 1 & 5,11 & & & 1,20 & & & 9,64 & & \\
\hline $03 / 04 / 2013$ & 21 & 2 & 2,87 & 4,68 & 1,64 & 0,48 & 0,70 & 0,44 & 10,74 & 9,75 & 0,94 \\
\hline $03 / 04 / 2013$ & & 3 & 6,06 & & & 0,40 & & & 8,87 & & \\
\hline $13 / 04 / 2013$ & & 1 & 0,46 & & & 0,04 & & & 27,62 & & \\
\hline $13 / 04 / 2013$ & 43 & 2 & 0,05 & 0,40 & 0,33 & 0,00 & 0,01 & 0,02 & 28,00 & 28,00 & 0,38 \\
\hline $13 / 04 / 2013$ & & 3 & 0,70 & & & 0,00 & & & 28,38 & & \\
\hline
\end{tabular}

年 


\begin{tabular}{|c|c|c|c|c|c|c|c|c|c|c|c|c|c|c|c|c|c|c|c|c|}
\hline Data & PP & Parcela & Pastagem & & Erosão & (Mg.ha-1) & & & & & & Cana-de-açúcar & & Erosão & $\begin{array}{l}\text { (Mg.ha-1) } \\
\text { (Mgla }\end{array}$ & & & & & \\
\hline $14 / 11 / 2011$ & & 1 & Colector & Media & Desvio & Caixa & Media & Desvio & Total & Media & Desvio & Colector & Media & Desvio & Caixa & Media & Desvio & Total & Media & Desvio \\
\hline 14/11/2011 & 308 & $\frac{1}{2}$ & $\begin{array}{l}0,04 \\
0,05\end{array}$ & O & & 0,01 & & & 0,05 & & & 0,33 & & & 0,00 & & & 0,33 & & \\
\hline $14 / 11 / 2011$ & 30,0 & 3 & 0,24 & 0,11 & 0,11 & $\begin{array}{l}0,02 \\
0,19\end{array}$ & 0,07 & 0,10 & $\begin{array}{l}0,06 \\
0,43\end{array}$ & 0,18 & 0,21 & 0,36 & 0,33 & 0,03 & 0,00 & 0,00 & 0,00 & 0,36 & 0,34 & 0,03 \\
\hline $15 / 11 / 2011$ & & 1 & 0,02 & & & 0,12 & & & 0,14 & & & 0,01 & & & 0,00 & & & 0,06 & & \\
\hline $\begin{array}{l}15 / 11 / 2011 \\
1\end{array}$ & 35,2 & 2 & 0,01 & 0,05 & 0,05 & 0,03 & 0,09 & 0,05 & 0,04 & 0,13 & 0,09 & 0,07 & 0,06 & 0,02 & 0,01 & 0,00 & 0,00 & 0,08 & 0,06 & 0,02 \\
\hline $15 / 11 / 2011$ & & 3 & 0,11 & & & 0,12 & & & 0,22 & & & 0,04 & & & 0,00 & & & 0,05 & & \\
\hline $22 / 11 / 2011$ & & 1 & 0,00 & & & 0,00 & & & 0,00 & & & 0,11 & & & 0,00 & & & 0,11 & & \\
\hline $22 / 11 / 2011$ & 10,2 & 2 & 0,00 & 0,00 & 0,00 & 0,00 & 0,00 & 0,00 & 0,00 & 0,00 & 0,00 & 0,12 & 0,12 & 0,01 & 0,00 & 0,00 & 0,00 & 0,12 & 0,12 & 0,01 \\
\hline $22 / 11 / 2011$ & & 3 & 0,00 & & & 0,00 & & & 0,00 & & & 0,11 & & & 0,00 & & & 0,11 & & \\
\hline $27 / 11 / 2011$ & & 1 & 0,02 & & & 0,00 & & & 0,02 & & & 0,12 & & & 0,00 & & & 0,12 & & \\
\hline $27 / 11 / 2011$ & 15,8 & 2 & 0,01 & 0,02 & 0,02 & 0,00 & 0,00 & 0,00 & 0,01 & 0,02 & 0,02 & 0,11 & 0,11 & 0,01 & 0,00 & 0,00 & 0,00 & 0,11 & 0,11 & 0,01 \\
\hline $27 / 11 / 2011$ & & 3 & 0,04 & & & 0,00 & & & 0,04 & & & 0,11 & 0,11 & & 0,00 & & & 0,11 & 0,11 & $0,0_{1}$ \\
\hline $30 / 11 / 2011$ & & 1 & 0,00 & & & 0,00 & & & 0,00 & & & 0,03 & & & 0,00 & & & 0,03 & & \\
\hline 30/11/2011 & 7,2 & 2 & 0,00 & 0,00 & 0,00 & 0,00 & 0,00 & 0,00 & 0,00 & 0,00 & 0,00 & 0,03 & 0,03 & 0,00 & 0,00 & 0,00 & 0,00 & 0,03 & 0,03 & 0,00 \\
\hline $30 / 11 / 2011$ & & 3 & 0,01 & & & 0,00 & & & 0,01 & & & 0,02 & & & 0,00 & & & 0,02 & & \\
\hline $06 / 12 / 2011$ & & 1 & 0,00 & & & 0,00 & & & 0,00 & & & 0,12 & & & 0,00 & & & 0,12 & & \\
\hline $06 / 12 / 2011$ & 6,4 & 2 & 0,00 & 0,00 & 0,00 & 0,00 & 0,00 & 0,00 & 0,00 & 0,00 & 0,00 & 0,10 & 0,11 & 0,01 & 0,00 & 0,00 & 0,00 & 0,10 & 0,11 & 0,01 \\
\hline $06 / 12 / 2011$ & & 3 & 0,01 & & & 0,00 & & & 0,01 & & & 0,10 & & & 0,00 & & & 0,10 & & \\
\hline $08 / 12 / 2011$ & & 1 & 0,01 & & & 0,00 & & & 0,01 & & & 0,03 & & & 0,00 & & & 0,03 & & \\
\hline $08 / 12 / 2011$ & 23 & 2 & 0,01 & 0,01 & 0,00 & 0,00 & 0,00 & 0,00 & 0,01 & 0,01 & 0,00 & 0,03 & 0,03 & 0,00 & 0,00 & 0,00 & 0,00 & 0,03 & 0,03 & 0,00 \\
\hline $08 / 12 / 2011$ & & 3 & 0,00 & & & 0,00 & & & 0,00 & & & 0,02 & & & 0,00 & & & 0,02 & & \\
\hline $10 / 12 / 2011$ & & 1 & 0,03 & & & 0,03 & & & 0,05 & & & 0,35 & & & 0,17 & & & 0,52 & & \\
\hline $10 / 12 / 2011$ & 101,4 & 2 & 0,03 & 0,04 & 0,02 & 0,00 & 0,01 & 0,02 & 0,03 & 0,05 & 0,02 & 0,30 & 0,29 & 0,07 & 0,09 & 0,10 & 0,07 & 0,39 & 0,39 & 0,14 \\
\hline $10 / 12 / 2011$ & & 3 & 0,07 & & & 0,00 & & & 0,07 & & & 0,21 & & & 0,04 & & & 0,25 & & \\
\hline $22 / 12 / 2011$ & & 1 & 0,01 & & & 0,00 & & & 0,01 & & & 0,04 & & & 0,00 & & & 0,04 & & \\
\hline $22 / 12 / 2011$ & 10,8 & 2 & 0,01 & 0,01 & 0,00 & 0,00 & 0,00 & 0,00 & 0,01 & 0,01 & 0,00 & 0,04 & 0,04 & 0,00 & 0,00 & 0,00 & 0,00 & 0,04 & 0,04 & 0,00 \\
\hline $22 / 12 / 2011$ & & 3 & 0,01 & & & 0,00 & & & 0,01 & & & 0,04 & & & 0,00 & & & 0,04 & & \\
\hline $24 / 12 / 2011$ & & 1 & 0,01 & & & 0,00 & & & 0,01 & & & 0,13 & & & 0,01 & & & $\begin{array}{l}0,0414 \\
0\end{array}$ & & \\
\hline $24 / 12 / 2011$ & 27,6 & 2 & 0,01 & 0,01 & 0,01 & 0,00 & 0,00 & 0,00 & 0,01 & 0,01 & 0,01 & 0,15 & 0,13 & 0,02 & 0,01 & 0,01 & 0,00 & 0,15 & 0,14 & 0,02 \\
\hline $24 / 12 / 2011$ & & 3 & 0,02 & & & 0,00 & & & 0,03 & & & 0,11 & & & 0,00 & & & 0,12 & & \\
\hline $01 / 01 / 2012$ & & 1 & 0,01 & & & 0,00 & & & 0,01 & & & 0,10 & & & 0,00 & & & 0,11 & & \\
\hline $01 / 01 / 2012$ & 53,8 & 2 & 0,01 & 0,01 & 0,00 & 0,00 & 0,00 & 0,00 & 0,01 & 0,01 & 0,00 & 0,12 & 0,10 & 0,01 & 0,00 & 0,00 & 0,00 & 0,12 & 0,11 & 0,01 \\
\hline $01 / 01 / 2012$ & & 3 & 0,02 & & & 0,00 & & & 0,02 & & & 0,09 & & & 0,00 & & & 0,09 & & \\
\hline $05 / 01 / 2012$ & & 1 & 0,00 & & & 0,00 & & & 0,00 & & & 0,01 & & & 0,00 & & & 0,01 & & \\
\hline $05 / 01 / 2012$ & 7,4 & 2 & 0,00 & 0,00 & 0,00 & 0,00 & 0,00 & 0,00 & 0,00 & 0,00 & 0,00 & 0,01 & 0,01 & 0,00 & 0,00 & 0,00 & 0,00 & 0,01 & 0,01 & 0,00 \\
\hline $05 / 01 / 2012$ & & 3 & 0,00 & & & 0,00 & & & 0,00 & & & 0,01 & & & 0,00 & & & 0,01 & & \\
\hline $08 / 01 / 2012$ & & 1 & 0,00 & & & 0,00 & & & 0,00 & & & 0,04 & & & 0,00 & & & 0,04 & & \\
\hline $08 / 01 / 2012$ & 10,4 & 2 & 0,00 & 0,00 & 0,00 & 0,00 & 0,00 & 0,00 & 0,00 & 0,00 & 0,00 & 0,04 & 0,04 & 0,00 & 0,00 & 0,00 & 0,00 & 0,04 & 0,04 & 0,00 \\
\hline $08 / 01 / 2012$ & & 3 & 0,00 & & & 0,00 & & & 0,00 & & & 0,04 & & & 0,00 & & & 0,04 & & \\
\hline $11 / 01 / 2012$ & & 1 & 0,01 & & & 0,00 & & & 0,01 & & & 0,01 & & & 0,00 & & & 0,01 & & \\
\hline $11 / 01 / 2012$ & 32,2 & 2 & 0,01 & 0,01 & 0,00 & 0,00 & 0,00 & 0,00 & 0,01 & 0,01 & 0,01 & 0,01 & 0,01 & 0,00 & 0,00 & 0,00 & 0,00 & 0,02 & 0,01 & 0,00 \\
\hline $\begin{array}{l}11 / 01 / 2012 \\
\end{array}$ & & 3 & 0,00 & & & 0,00 & & & 0,00 & & & 0,01 & & & 0,00 & & & 0,01 & & \\
\hline $16 / 01 / 2012$ & & 1 & 0,00 & & & 0,00 & & & 0,00 & & & 0,04 & & & 0,00 & & & 0,04 & & \\
\hline $16 / 01 / 2012$ & 9,8 & 2 & 0,00 & 0,00 & 0,00 & 0,00 & 0,00 & 0,00 & 0,00 & 0,00 & 0,00 & 0,03 & 0,03 & 0,01 & 0,00 & 0,00 & 0,00 & 0,03 & 0,03 & 0,01 \\
\hline $16 / 01 / 2012$ & & 3 & 0,01 & & & 0,00 & & & 0,01 & & & 0,03 & & & 0,00 & & & 0,03 & & \\
\hline $17 / 01 / 2012$ & & 1 & 0,01 & & & 0,00 & & & 0,01 & & & 0,07 & & & 0,02 & & & 0,09 & & \\
\hline $17 / 01 / 2012$ & 17,6 & 2 & 0,00 & 0,01 & 0,00 & 0,00 & 0,00 & 0,00 & 0,00 & 0,01 & 0,00 & 0,05 & 0,06 & 0,01 & 0,01 & 0,01 & 0,01 & 0,06 & 0,07 & 0,02 \\
\hline $17 / 01 / 2012$ & & 3 & 0,01 & & & 0,00 & & & 0,01 & & & 0,05 & & & 0,01 & & & 0,06 & & \\
\hline
\end{tabular}




\begin{tabular}{|c|c|c|c|c|c|c|c|c|c|c|c|c|c|c|c|c|c|c|c|c|}
\hline Data & PP & Parcela & Pastagem & & Erosão & (Mg.ha-1) & & & & & & Cana-de-açúcar & & Erosão & $\begin{array}{l}\text { (Mg.ha-1) } \\
\text { (M.hal }\end{array}$ & & & & & \\
\hline & & & Colector & Media & Desvio & Caixa & Media & Desvio & Total & Media & Desvio & Colector & Media & Desvio & Caixa & Media & Desvio & Total & Media & Desvio \\
\hline $18 / 01 / 2012$ & & 1 & 0,00 & & & 0,00 & & & 0,00 & & & 0,04 & & & 0,01 & & & 0,04 & & \\
\hline 18/01/2012 & 18,8 & 2 & 0,00 & 0,00 & 0,00 & 0,00 & 0,00 & 0,00 & 0,00 & 0,00 & 0,00 & 0,04 & 0,03 & 0,00 & 0,00 & 0,00 & 0,00 & 0,04 & 0,04 & 0,00 \\
\hline $18 / 01 / 2012$ & & 3 & 0,00 & & & 0,00 & & & 0,00 & & & 0,03 & & & 0,00 & & & 0,03 & & \\
\hline $19 / 01 / 2012$ & & 1 & 0,01 & & & 0,01 & & & 0,02 & & & 0,02 & & & 0,08 & & & 0,10 & & \\
\hline $19 / 01 / 2012$ & 17 & 2 & 0,00 & 0,01 & 0,01 & 0,00 & 0,01 & 0,00 & 0,01 & 0,02 & 0,01 & 0,02 & 0,02 & 0,01 & 0,06 & 0,07 & 0,01 & 0,08 & 0,09 & 0,01 \\
\hline $19 / 01 / 2012$ & & 3 & 0,02 & & & 0,01 & & & 0,03 & & & 0,01 & & & 0,07 & & & 0,08 & & \\
\hline $20 / 01 / 2012$ & & 1 & 0,00 & & & 0,00 & & & 0,00 & & & 0,01 & & & 0,00 & & & 0,01 & & \\
\hline 20/01/2012 & 11,2 & 2 & 0,00 & 0,00 & 0,00 & 0,00 & 0,00 & 0,00 & 0,00 & 0,00 & 0,00 & 0,01 & 0,01 & 0,00 & 0,00 & 0,00 & 0,00 & 0,01 & 0,01 & 0,00 \\
\hline $20 / 01 / 2012$ & & 3 & 0,00 & & & 0,00 & & & 0,00 & & & 0,01 & & & 0,00 & & & 0,01 & & \\
\hline $21 / 01 / 2012$ & & 1 & 0,00 & & & 0,00 & & & 0,00 & & & 0,03 & & & 0,00 & & & 0,03 & & \\
\hline $21 / 01 / 2012$ & 12,8 & 2 & 0,00 & 0,00 & 0,00 & 0,00 & 0,00 & 0,00 & 0,00 & 0,00 & 0,00 & 0,03 & 0,03 & 0,00 & 0,00 & 0,00 & 0,00 & 0,03 & 0,03 & 0,00 \\
\hline $21 / 01 / 2012$ & & 3 & 0,00 & & & 0,00 & & & 0,00 & & & 0,02 & & & 0,00 & & & 0,02 & & \\
\hline $22 / 01 / 2012$ & & 1 & 0,00 & & & 0,01 & & & 0,01 & & & 0,02 & & & 0,08 & & & 0,10 & & \\
\hline $22 / 01 / 2012$ & 16,6 & 2 & 0,01 & 0,01 & 0,01 & 0,01 & 0,01 & 0,00 & 0,01 & 0,02 & 0,01 & 0,02 & 0,02 & 0,00 & 0,07 & 0,07 & 0,02 & 0,09 & 0,09 & 0,02 \\
\hline $22 / 01 / 2012$ & & 3 & 0,02 & & & 0,01 & & & 0,03 & & & 0,01 & & & 0,05 & & & 0,06 & & \\
\hline $26 / 01 / 2012$ & & 1 & 0,00 & & & 0,00 & & & 0,00 & & & 0,05 & & & 0,00 & & & 0,05 & & \\
\hline $26 / 01 / 2012$ & 6 & 2 & 0,00 & 0,00 & 0,00 & 0,00 & 0,00 & 0,00 & 0,00 & 0,00 & 0,00 & 0,03 & 0,03 & 0,01 & 0,00 & 0,00 & 0,00 & 0,03 & 0,04 & 0,01 \\
\hline $26 / 01 / 2012$ & & 3 & 0,00 & & & 0,00 & & & 0,00 & & & 0,03 & & & 0,00 & & & 0,03 & & \\
\hline $26 / 01 / 2012$ & & 1 & 0,00 & & & 0,00 & & & 0,00 & & & 0,02 & & & 0,00 & & & 0,02 & & \\
\hline $26 / 01 / 2012$ & 9,2 & 2 & 0,00 & 0,00 & 0,00 & 0,00 & 0,00 & 0,00 & 0,00 & 0,00 & 0,00 & 0,01 & 0,02 & 0,00 & 0,00 & 0,00 & 0,00 & 0,02 & 0,02 & 0,00 \\
\hline $26 / 01 / 2012$ & & 3 & 0,00 & & & 0,00 & & & 0,00 & & & 0,01 & & & 0,00 & & & 0,01 & & \\
\hline $28 / 01 / 2012$ & & 1 & 0,00 & & & 0,00 & & & 0,01 & & & 0,01 & & & 0,00 & & & 0,02 & & \\
\hline 28/01/2012 & 21 & 2 & 0,00 & 0,00 & 0,00 & 0,00 & 0,00 & 0,00 & 0,00 & 0,01 & 0,00 & 0,01 & 0,01 & 0,00 & 0,00 & 0,00 & 0,00 & 0,01 & 0,01 & 0,00 \\
\hline $28 / 01 / 2012$ & & 3 & 0,01 & & & 0,00 & & & 0,01 & & & 0,01 & & & 0,00 & & & 0,01 & & \\
\hline $11 / 02 / 2012$ & & 1 & 0,01 & & & 0,00 & & & 0,01 & & & 0,11 & & & 0,01 & & & 0,12 & & \\
\hline $11 / 02 / 2012$ & 25,6 & 2 & 0,01 & 0,01 & 0,00 & 0,00 & 0,00 & 0,00 & 0,01 & 0,01 & 0,00 & 0,07 & 0,08 & 0,03 & 0,00 & 0,00 & 0,00 & 0,07 & 0,08 & 0,03 \\
\hline $11 / 02 / 2012$ & & 3 & 0,01 & & & 0,00 & & & 0,01 & & & 0,06 & & & 0,00 & & & 0,06 & & \\
\hline $12 / 02 / 2012$ & & 1 & 0,00 & & & 0,00 & & & 0,00 & & & 0,03 & & & 0,01 & & & 0,04 & & \\
\hline $12 / 02 / 2012$ & 34,8 & 2 & 0,00 & 0,00 & 0,00 & 0,00 & 0,00 & 0,00 & 0,00 & 0,00 & 0,00 & 0,03 & 0,03 & 0,01 & 0,00 & 0,01 & 0,00 & 0,03 & 0,03 & 0,01 \\
\hline $12 / 02 / 2012$ & & 3 & 0,00 & & & 0,00 & & & 0,00 & & & 0,02 & & & 0,00 & & & 0,02 & & \\
\hline $19 / 02 / 2012$ & & 1 & 0,00 & & & 0,00 & & & 0,00 & & & 0,08 & & & 0,00 & & & 0,08 & & \\
\hline $19 / 02 / 2012$ & 8,8 & 2 & 0,00 & 0,00 & 0,00 & 0,00 & 0,00 & 0,00 & 0,00 & 0,00 & 0,00 & 0,04 & 0,05 & 0,02 & 0,00 & 0,00 & 0,00 & 0,04 & 0,05 & 0,02 \\
\hline $19 / 02 / 2012$ & & 3 & 0,00 & & & 0,00 & & & 0,00 & & & 0,04 & & & 0,00 & & & 0,04 & & \\
\hline $24 / 02 / 2012$ & & 1 & 0,01 & & & 0,01 & & & 0,02 & & & 0,15 & & & 0,12 & & & 0,27 & & \\
\hline $23 / 02 / 2012$ & 51,4 & 2 & 0,01 & 0,01 & 0,00 & 0,00 & 0,00 & 0,01 & 0,01 & 0,02 & 0,00 & 0,08 & 0,10 & 0,04 & 0,08 & 0,09 & 0,03 & 0,16 & 0,19 & 0,07 \\
\hline $24 / 02 / 2012$ & & 3 & 0,01 & & & 0,00 & & & 0,01 & & & 0,07 & & & 0,07 & & & 0,14 & & \\
\hline $27 / 02 / 2012$ & & 1 & 0,01 & & & 0,00 & & & 0,01 & & & 0,09 & & & 0,02 & & & 0,11 & & \\
\hline $27 / 02 / 2012$ & 28,4 & 2 & 0,00 & 0,00 & 0,00 & 0,00 & 0,00 & 0,00 & 0,00 & 0,00 & 0,00 & 0,04 & 0,05 & 0,03 & 0,01 & 0,02 & 0,00 & 0,06 & 0,07 & 0,03 \\
\hline $27 / 02 / 2012$ & & 3 & 0,00 & & & 0,00 & & & 0,01 & & & 0,03 & & & 0,02 & & & 0,04 & & \\
\hline $01 / 03 / 2012$ & & 1 & 0,00 & & & 0,00 & & & 0,00 & & & 0,05 & & & 0,00 & & & 0,05 & & \\
\hline $01 / 03 / 2012$ & 17,8 & 2 & 0,00 & 0,00 & 0,00 & 0,00 & 0,00 & 0,00 & 0,00 & 0,00 & 0,00 & 0,03 & 0,03 & 0,02 & 0,00 & 0,00 & 0,00 & 0,03 & 0,03 & 0,02 \\
\hline $01 / 03 / 2012$ & & 3 & 0,00 & & & 0,00 & & & 0,00 & & & 0,02 & & & 0,00 & & & 0,02 & & \\
\hline $03 / 03 / 2012$ & & 1 & 0,00 & & & 0,00 & & & 0,00 & & & 0,04 & & & 0,00 & & & 0,04 & & \\
\hline 03/03/2012 & 12,8 & 2 & 0,00 & 0,00 & 0,00 & 0,00 & 0,00 & 0,00 & 0,00 & 0,00 & 0,00 & 0,02 & 0,02 & 0,01 & 0,00 & 0,00 & 0,00 & 0,02 & 0,02 & 0,01 \\
\hline $03 / 03 / 2012$ & & 3 & 0,00 & & & 0,00 & & & 0,00 & & & 0,01 & & & 0,00 & & & 0,01 & & \\
\hline $15 / 03 / 2012$ & & 1 & 0,00 & & & 0,00 & & & 0,00 & & & 0,02 & & & 0,00 & & & 0,02 & & \\
\hline 15/03/2012 & 8,2 & 2 & 0,00 & 0,00 & 0,00 & 0,00 & 0,00 & 0,00 & 0,00 & 0,00 & 0,00 & 0,01 & 0,01 & 0,01 & 0,00 & 0,00 & 0,00 & 0,01 & 0,01 & 0,01 \\
\hline $15 / 03 / 2012$ & & 3 & 0,00 & & & 0,00 & & & 0,00 & & & 0,01 & & & 0,00 & & & 0,01 & & \\
\hline 09/04/2012 & & 1 & 0,00 & & & 0,00 & & & 0,00 & & & 0,02 & & & 0,00 & & & 0,02 & & \\
\hline 09/04/2012 & 9,4 & 2 & 0,00 & 0,00 & 0,00 & 0,00 & 0,00 & 0,00 & 0,00 & 0,00 & 0,00 & 0,01 & 0,01 & 0,01 & 0,00 & 0,00 & 0,00 & 0,01 & 0,01 & 0,01 \\
\hline 09/04/2012 & & 3 & 0,00 & & & 0,00 & & & 0,00 & & & 0,01 & & & 0,00 & & & 0,01 & & \\
\hline
\end{tabular}




\begin{tabular}{|c|c|c|c|c|c|c|c|c|c|c|c|c|c|c|c|c|c|c|c|c|}
\hline Data & PP & Parcela & $\begin{array}{l}\text { Pastagem } \\
\text { Colector }\end{array}$ & Media & $\begin{array}{l}\text { Erosão } \\
\text { Desvio }\end{array}$ & $\begin{array}{c}\text { (Mg.ha-1) } \\
\text { Caixa }\end{array}$ & Media & Desvio & Total & Media & Desvio & $\begin{array}{l}\text { Cana-de-açúcar } \\
\text { colector }\end{array}$ & Media & $\begin{array}{l}\text { Erosão } \\
\text { Desvio }\end{array}$ & $\begin{array}{l}\text { (Mg.ha-1) } \\
\text { Gaixa }\end{array}$ & Media & Desvio & Total & Media & Desvio \\
\hline $21 / 04 / 2012$ & & 1 & 0,00 & & & 0,00 & & & 0,00 & & & 0,03 & & Desio & 0,000 & & & 0,03 & & \\
\hline $\begin{array}{l}21 / 04 / 2012 \\
21 / 04 / 2012\end{array}$ & 31,8 & $\begin{array}{l}2 \\
3\end{array}$ & $\begin{array}{l}0,00 \\
0,00\end{array}$ & 0,00 & 0,00 & $\begin{array}{l}0,00 \\
0,00\end{array}$ & 0,00 & 0,00 & $\begin{array}{l}0,00 \\
0,00\end{array}$ & 0,00 & 0,00 & 0,01 & 0,02 & 0,01 & $\begin{array}{l}0,00 \\
0,00\end{array}$ & 0,00 & 0,00 & $\begin{array}{l}0,01 \\
0,01\end{array}$ & 0,02 & 0,01 \\
\hline $26 / 04 / 2012$ & & 1 & 0,00 & & & 0,00 & & & 0,00 & & & $\frac{0,01}{0,02}$ & & & 0,00 & & & 0,02 & & \\
\hline $\begin{array}{l}26 / 04 / 2012 \\
26 / 04 / 2012\end{array}$ & 11,8 & $\begin{array}{l}2 \\
3\end{array}$ & $\begin{array}{l}0,00 \\
0,00\end{array}$ & 0,00 & 0,00 & $\begin{array}{l}0,00 \\
0,00\end{array}$ & 0,00 & 0,00 & $\begin{array}{l}0,00 \\
0,00\end{array}$ & 0,00 & 0,00 & $\begin{array}{l}0,01 \\
0,01\end{array}$ & 0,01 & 0,01 & $\begin{array}{l}0,00 \\
0,00\end{array}$ & 0,00 & 0,00 & $\begin{array}{l}0,01 \\
0,01\end{array}$ & 0,01 & 0,01 \\
\hline $30 / 04 / 2012$ & & 1 & 0,00 & & & 0,00 & & & 0,00 & & & 0,02 & & & 0,00 & & & 0,02 & & \\
\hline $30 / 04 / 2012$ & 65,2 & 2 & 0,00 & 0,00 & 0,00 & 0,00 & 0,00 & 0,00 & 0,00 & 0,00 & 0,00 & 0,01 & 0,01 & 0,01 & 0,00 & 0,00 & 0,00 & 0,01 & 0,01 & 0,01 \\
\hline $30 / 04 / 2012$ & & 3 & 0,00 & & & 0,00 & & & 0,00 & & & 0,01 & & & 0,00 & & & 0,01 & & \\
\hline $14 / 05 / 2012$ & & 1 & 0,00 & & & 0,00 & & & 0,00 & & & 0,01 & & & 0,00 & & & 0,01 & & \\
\hline $14 / 05 / 2012$ & 43 & 2 & 0,00 & 0,00 & 0,00 & 0,00 & 0,00 & 0,00 & 0,00 & 0,00 & 0,00 & 0,01 & 0,01 & 0,00 & 0,00 & 0,00 & 0,00 & 0,01 & 0,01 & 0,00 \\
\hline $14 / 05 / 2012$ & & 3 & 0,00 & & & 0,00 & & & 0,00 & & & 0,01 & & & 0,00 & & & 0,01 & & \\
\hline 08/06/2012 & & 1 & 0,00 & & & 0,00 & & & 0,00 & & & 0,01 & & & 0,00 & & & 0,02 & & \\
\hline $\begin{array}{l}08 / 06 / 2012 \\
08 / 06 / 2012\end{array}$ & 47,6 & $\begin{array}{l}2 \\
3\end{array}$ & $\begin{array}{l}0,00 \\
0,00\end{array}$ & 0,00 & 0,00 & $\begin{array}{l}0,00 \\
0,00\end{array}$ & 0,00 & 0,00 & $\begin{array}{l}0,00 \\
0,00\end{array}$ & 0,00 & 0,00 & $\begin{array}{l}0,01 \\
0,01\end{array}$ & 0,01 & 0,00 & $\begin{array}{l}0,00 \\
0,00\end{array}$ & 0,00 & 0,00 & $\begin{array}{l}0,01 \\
0,01\end{array}$ & 0,01 & 0,00 \\
\hline $22 / 06 / 2012$ & & 1 & 0,00 & & & 0,00 & & & 0,00 & & & 0,01 & & & 0,00 & & & 0,01 & & \\
\hline 22/06/2012 & 73,8 & 2 & 0,00 & 0,00 & 0,00 & 0,00 & 0,00 & 0,00 & 0,00 & 0,00 & 0,00 & 0,01 & 0,01 & 0,00 & 0,00 & 0,00 & 0,00 & 0,01 & 0,01 & 0,00 \\
\hline $22 / 06 / 2012$ & & 3 & 0,00 & & & 0,00 & & & 0,00 & & & 0,01 & & & 0,00 & & & 0,01 & & \\
\hline $17 / 07 / 2012$ & & 1 & 0,00 & & & 0,00 & & & 0,00 & & & 0,01 & & & 0,00 & & & 0,01 & & \\
\hline 17/07/2012 & 16,6 & 2 & 0,00 & 0,00 & 0,00 & 0,00 & 0,00 & 0,00 & 0,00 & 0,00 & 0,00 & 0,01 & 0,01 & 0,00 & 0,00 & 0,00 & 0,00 & 0,01 & 0,01 & 0,00 \\
\hline $17 / 07 / 2012$ & & 3 & 0,00 & & & 0,00 & & & 0,00 & & & 0,01 & & & 0,00 & & & 0,01 & & \\
\hline $21 / 09 / 2012$ & & 1 & 0,00 & & & 0,00 & & & 0,00 & & & 0,01 & & & 0,00 & & & 0,01 & & \\
\hline $21 / 09 / 2012$ & 45,8 & 2 & 0,00 & 0,00 & 0,00 & 0,00 & 0,00 & 0,00 & 0,00 & 0,00 & 0,00 & 0,01 & 0,01 & 0,00 & 0,00 & 0,00 & 0,00 & 0,01 & 0,01 & 0,00 \\
\hline $21 / 09 / 2012$ & & 3 & 0,00 & & & 0,00 & & & 0,00 & & & 0,00 & & & 0,00 & & & 0,00 & & \\
\hline $25 / 09 / 2012$ & & 1 & 0,00 & & & 0,00 & & & 0,00 & & & 0,01 & & & 0,01 & & & 0,02 & & \\
\hline 25/09/2012 & 19,2 & 2 & 0,00 & 0,00 & 0,00 & 0,00 & 0,00 & 0,00 & 0,00 & 0,00 & 0,00 & 0,01 & 0,01 & 0,01 & 0,00 & 0,00 & 0,00 & 0,01 & 0,01 & 0,01 \\
\hline $25 / 09 / 2012$ & & 3 & 0,00 & & & 0,00 & & & 0,00 & & & 0,00 & & & 0,00 & & & 0,00 & & \\
\hline $24 / 10 / 2012$ & & 1 & 0,01 & & & 0,00 & & & 0,01 & & & 0,01 & & & 0,00 & & & 0,02 & & \\
\hline 24/10/2012 & 33,6 & 2 & 0,01 & 0,01 & 0,00 & 0,00 & 0,00 & 0,00 & 0,01 & 0,01 & 0,00 & 0,01 & 0,01 & 0,00 & 0,00 & 0,00 & 0,00 & 0,01 & 0,01 & 0,00 \\
\hline $24 / 10 / 2012$ & & 3 & 0,00 & & & 0,00 & & & 0,00 & & & 0,01 & & & 0,00 & & & 0,01 & & \\
\hline $25 / 10 / 2012$ & & 1 & 0,00 & & & 0,00 & & & $\begin{array}{ll}0,01 \\
\end{array}$ & & & 0,01 & & & 0,01 & & & 0,01 & & \\
\hline $25 / 10 / 2012$ & 27,4 & 2 & 0,00 & 0,00 & 0,00 & 0,01 & 0,01 & 0,00 & 0,01 & 0,01 & 0,00 & 0,00 & 0,00 & 0,00 & 0,01 & 0,01 & 0,00 & 0,01 & 0,01 & 0,00 \\
\hline $25 / 10 / 2012$ & & 3 & 0,00 & & & 0,01 & & & 0,01 & & & 0,00 & & & 0,01 & & & 0,01 & & \\
\hline $09 / 11 / 2012$ & & 1 & 0,00 & & & 0,00 & & & 0,00 & & & 0,02 & & & 0,00 & & & 0,02 & & \\
\hline 09/11/2012 & 33,2 & 2 & 0,00 & 0,00 & 0,00 & 0,00 & 0,00 & 0,00 & 0,00 & 0,00 & 0,00 & 0,02 & 0,02 & 0,00 & 0,00 & 0,00 & 0,00 & 0,02 & 0,02 & 0,00 \\
\hline $\begin{array}{l}09 / 11 / 2012 \\
\end{array}$ & & 3 & 0,00 & & & 0,00 & & & 0,00 & & & 0,02 & & & 0,00 & & & 0,02 & & \\
\hline $03 / 12 / 2012$ & & 1 & 0,00 & & & 0,00 & & & 0,00 & & & 0,09 & & & 0,00 & & & 0,09 & & \\
\hline 03/12/2012 & 38,4 & 2 & 0,00 & 0,00 & 0,00 & 0,00 & 0,00 & 0,00 & 0,00 & 0,00 & 0,00 & 0,09 & 0,09 & 0,00 & 0,00 & 0,00 & 0,00 & 0,09 & 0,09 & 0,00 \\
\hline $03 / 12 / 2012$ & & 3 & 0,00 & & & 0,00 & & & 0,00 & & & 0,09 & & & 0,00 & & & 0,09 & & \\
\hline $10 / 12 / 2012$ & & 1 & 0,00 & & & 0,00 & & & 0,00 & & & 0,06 & & & 0,00 & & & 0,06 & & \\
\hline $10 / 12 / 2012$ & 12,8 & 2 & 0,00 & 0,00 & 0,00 & 0,00 & 0,00 & 0,00 & 0,00 & 0,00 & 0,00 & 0,07 & 0,07 & 0,00 & 0,00 & 0,00 & 0,00 & 0,07 & 0,07 & 0,00 \\
\hline $10 / 12 / 2012$ & & 3 & 0,00 & & & 0,00 & & & 0,00 & & & 0,07 & & & 0,00 & & & 0,07 & & \\
\hline $13 / 12 / 2012$ & & 1 & 0,00 & & & 0,00 & & & 0,00 & & & 0,01 & & & 0,00 & & & 0,01 & & \\
\hline $13 / 12 / 2012$ & 19,4 & 2 & 0,00 & 0,00 & 0,00 & 0,00 & 0,00 & 0,00 & 0,00 & 0,00 & 0,00 & 0,01 & 0,01 & 0,00 & 0,00 & 0,00 & 0,00 & 0,01 & 0,01 & 0,00 \\
\hline $\begin{array}{l}13 / 12 / 2012 \\
\end{array}$ & & 3 & 0,00 & & & 0,00 & & & 0,00 & & & 0,01 & & & 0,00 & & & 0,01 & & \\
\hline $13 / 12 / 2012$ & & 1 & 0,00 & & & 0,00 & & & 0,00 & & & 0,01 & & & 0,00 & & & 0,01 & & \\
\hline $13 / 12 / 2012$ & 14,8 & 2 & 0,00 & 0,00 & 0,00 & 0,00 & 0,00 & 0,00 & 0,00 & 0,00 & 0,00 & 0,02 & 0,01 & 0,00 & 0,00 & 0,00 & 0,00 & 0,02 & 0,01 & 0,00 \\
\hline $13 / 12 / 2012$ & & 3 & 0,00 & & & 0,00 & & & 0,00 & & & 0,01 & & & 0,00 & & & 0,01 & & \\
\hline
\end{tabular}




\begin{tabular}{|c|c|c|c|c|c|c|c|c|c|c|c|c|c|c|c|c|c|c|c|c|}
\hline \multirow{2}{*}{ Data } & \multirow{2}{*}{ PP } & \multirow{2}{*}{ Parcela } & \multirow{2}{*}{\begin{tabular}{|c|}
$\begin{array}{c}\text { Pastagem } \\
\text { Colector }\end{array}$ \\
\end{tabular}} & \multirow[b]{2}{*}{ Media } & \multirow{2}{*}{$\begin{array}{l}\text { Erosão } \\
\text { Desvio }\end{array}$} & \multirow{2}{*}{$\begin{array}{c}\text { (Mg.ha-1) } \\
\text { Caixa }\end{array}$} & \multirow[b]{2}{*}{ Media } & \multirow[b]{2}{*}{ Desvio } & \multirow[b]{2}{*}{ Total } & \multirow[b]{2}{*}{ Media } & \multirow[b]{2}{*}{ Desvio } & Cana-de-açúcar & & Erosão & (Mg.ha-1) & & & & & \\
\hline & & & & & & & & & & & & \begin{tabular}{|l} 
Colector \\
\end{tabular} & Media & Desvio & Caixa & Media & Desvio & Total & Media & Desvio \\
\hline $17 / 12 / 2012$ & & 1 & 0,00 & & & 0,00 & & & 0,00 & & & 0,06 & & & 0,00 & & & 0,06 & & \\
\hline $17 / 12 / 2012$ & 60,8 & 2 & 0,00 & 0,00 & 0,00 & 0,00 & 0,00 & 0,00 & 0,00 & 0,00 & 0,00 & 0,08 & 0,07 & 0,01 & 0,00 & 0,00 & 0,00 & 0,08 & 0,07 & 0,01 \\
\hline $17 / 12 / 2012$ & & 3 & 0,00 & & & 0,00 & & & 0,00 & & & 0,06 & & & 0,00 & & & 0,07 & & \\
\hline $28 / 12 / 2012$ & & 1 & 0,00 & & & 0,00 & & & 0,01 & & & 0,07 & & & 0,01 & & & 0,08 & & \\
\hline $28 / 12 / 2012$ & 38,2 & 2 & 0,01 & 0,01 & 0,00 & 0,00 & 0,00 & 0,00 & 0,01 & 0,01 & 0,00 & 0,08 & 0,07 & 0,01 & 0,00 & 0,01 & 0,00 & 0,09 & 0,08 & 0,01 \\
\hline $28 / 12 / 2012$ & & 3 & 0,01 & & & 0,00 & & & 0,01 & & & 0,06 & & & 0,01 & & & 0,07 & & \\
\hline $13 / 01 / 2013$ & & 1 & 0,00 & & & 0,00 & & & 0,00 & & & 0,04 & & & 0,00 & & & 0,05 & & \\
\hline $13 / 01 / 2013$ & 93,6 & 2 & 0,00 & 0,00 & 0,00 & 0,00 & 0,00 & 0,00 & 0,00 & 0,00 & 0,00 & 0,04 & 0,04 & 0,01 & 0,00 & 0,00 & 0,00 & 0,04 & 0,04 & 0,01 \\
\hline $13 / 01 / 2013$ & & 3 & 0,00 & & & 0,00 & & & 0,01 & & & 0,03 & & & 0,00 & & & 0,03 & & \\
\hline $15 / 01 / 2013$ & & 1 & 0,00 & & & 0,00 & & & 0,00 & & & 0,01 & & & 0,00 & & & 0,01 & & \\
\hline $15 / 01 / 2013$ & 22,6 & 2 & 0,00 & 0,00 & 0,00 & 0,00 & 0,00 & 0,00 & 0,00 & 0,00 & 0,00 & 0,00 & 0,00 & 0,00 & 0,00 & 0,00 & 0,00 & 0,00 & 0,01 & 0,00 \\
\hline $15 / 01 / 2013$ & & 3 & 0,00 & & & 0,00 & & & 0,00 & & & 0,00 & & & 0,00 & & & 0,00 & & 0 \\
\hline $17 / 01 / 2013$ & & 1 & 0,00 & & & 0,00 & & & 0,00 & & & 0,01 & & & 0,00 & & & 0,01 & & \\
\hline $17 / 01 / 2013$ & 20,6 & 2 & 0,00 & 0,00 & 0,00 & 0,00 & 0,00 & 0,00 & 0,00 & 0,00 & 0,00 & 0,02 & 0,01 & 0,00 & 0,00 & 0,00 & 0,00 & 0,02 & 0,01 & 0,00 \\
\hline $17 / 01 / 2013$ & & 3 & 0,00 & & & 0,00 & & & 0,00 & & & 0,01 & & & 0,00 & & & 0,01 & & \\
\hline $23 / 01 / 2013$ & & 1 & 0,00 & & & 0,00 & & & 0,00 & & & 0,02 & & & 0,00 & & & 0,02 & & \\
\hline $23 / 01 / 2013$ & 9 & 2 & 0,00 & 0,00 & 0,00 & 0,00 & 0,00 & 0,00 & 0,00 & 0,00 & 0,00 & 0,01 & 0,01 & 0,00 & 0,00 & 0,00 & 0,00 & 0,01 & 0,01 & 0,00 \\
\hline $23 / 01 / 2013$ & & 3 & 0,00 & & & 0,00 & & & 0,00 & & & 0,01 & & & 0,00 & & & 0,01 & & \\
\hline $04 / 02 / 2013$ & & 1 & 0,00 & & & 0,00 & & & 0,00 & & & 0,02 & & & 0,00 & & & 0,02 & & \\
\hline $04 / 02 / 2013$ & 17,4 & 2 & 0,00 & 0,00 & 0,00 & 0,00 & 0,00 & 0,00 & 0,00 & 0,00 & 0,00 & 0,01 & 0,01 & 0,01 & 0,00 & 0,00 & 0,00 & 0,01 & 0,01 & 0,01 \\
\hline $04 / 02 / 2013$ & & 3 & 0,00 & & & 0,00 & & & 0,00 & & & 0,01 & 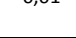 & & 0,00 & & & 0,01 & 0,0 & 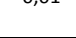 \\
\hline $06 / 02 / 2013$ & & 1 & 0,00 & & & 0,00 & & & 0,00 & & & 0,01 & & & 0,01 & & & 0,01 & & \\
\hline 06/02/2013 & 26,6 & 2 & 0,00 & 0,00 & 0,00 & 0,00 & 0,00 & 0,00 & 0,00 & 0,00 & 0,00 & 0,00 & 0,00 & 0,00 & 0,00 & 0,00 & 0,00 & 0,01 & 0,01 & 0,00 \\
\hline $06 / 02 / 2013$ & & 3 & 0,00 & & & 0,00 & & & 0,00 & & & 0,00 & & & 0,00 & & & 0,00 & & \\
\hline $09 / 02 / 2013$ & & 1 & 0,00 & & & 0,00 & & & 0,00 & & & 0,00 & & & 0,00 & & & 0,00 & & \\
\hline $09 / 02 / 2013$ & 11,2 & 2 & 0,00 & 0,00 & 0,00 & 0,00 & 0,00 & 0,00 & 0,00 & 0,00 & 0,00 & 0,00 & 0,00 & 0,00 & 0,00 & 0,00 & 0,00 & 0,00 & 0,00 & 0,00 \\
\hline 09/02/2013 & & 3 & 0,00 & & & 0,00 & & & 0,00 & & & 0,00 & & & 0,00 & & & 0,00 & & \\
\hline $27 / 02 / 2013$ & & 1 & 0,00 & & & 0,00 & & & 0,00 & & & 0,00 & & & 0,00 & & & 0,00 & & \\
\hline $27 / 02 / 2013$ & 11,4 & 2 & 0,00 & 0,00 & 0,00 & 0,00 & 0,00 & 0,00 & 0,00 & 0,00 & 0,00 & 0,00 & 0,00 & 0,00 & 0,00 & 0,00 & 0,00 & 0,00 & 0,00 & 0,00 \\
\hline $27 / 02 / 2013$ & & 3 & 0,00 & 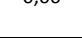 & & 0,00 & & & 0,00 & 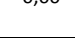 & 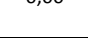 & 0,00 & 0 &, 00 & 0,00 & 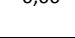 & 0,0 & 0,00 & & 0 \\
\hline $04 / 03 / 2013$ & & 1 & 0,00 & & & 0,00 & & & 0,00 & & & 0,00 & & & 0,00 & & & 0,00 & & \\
\hline $04 / 03 / 2013$ & 13,2 & 2 & 0,00 & 0,00 & 0,00 & 0,00 & 0,00 & 0,00 & 0,00 & 0,00 & 0,00 & 0,00 & 0,00 & 0,00 & 0,00 & 0,00 & 0,00 & 0,00 & 0,00 & 0,00 \\
\hline $04 / 03 / 2013$ & & 3 & 0,00 & & & 0,00 & & & 0,00 & & & 0,00 & & & 0,00 & & & 0,00 & & \\
\hline $11 / 03 / 2013$ & & 1 & 0,00 & & & 0,00 & & & 0,00 & & & 0,00 & & & 0,00 & & & 0,00 & & \\
\hline $11 / 03 / 2013$ & 30 & 2 & 0,00 & 0,00 & 0,00 & 0,00 & 0,00 & 0,00 & 0,00 & 0,00 & 0,00 & 0,00 & 0,00 & 0,00 & 0,00 & 0,00 & 0,00 & 0,00 & 0,00 & 0,00 \\
\hline $11 / 03 / 2013$ & & 3 & 0,00 & & & 0,00 & & & 0,00 & & & 0,00 & & & 0,00 & & & 0,00 & & \\
\hline $12 / 03 / 2013$ & & 1 & 0,00 & & & 0,00 & & & 0,00 & & & 0,00 & & & 0,00 & & & 0,01 & & \\
\hline $12 / 03 / 2013$ & 27,4 & 2 & 0,00 & 0,00 & 0,00 & 0,00 & 0,00 & 0,00 & 0,00 & 0,00 & 0,00 & 0,00 & 0,00 & 0,00 & 0,00 & 0,00 & 0,00 & 0,00 & 0,00 & 0,00 \\
\hline $12 / 03 / 2013$ & & 3 & 0,00 & & & 0,00 & & & 0,00 & & & 0,00 & & & 0,00 & & & 0,00 & & \\
\hline $13 / 03 / 2013$ & & 1 & 0,00 & & & 0,00 & & & 0,00 & & & 0,00 & & & 0,00 & & & 0,00 & & \\
\hline $13 / 03 / 2013$ & 14,2 & 2 & 0,00 & 0,00 & 0,00 & 0,00 & 0,00 & 0,00 & 0,00 & 0,00 & 0,00 & 0,00 & 0,00 & 0,00 & 0,00 & 0,00 & 0,00 & 0,00 & 0,00 & 0,00 \\
\hline $13 / 03 / 2013$ & & 3 & 0,00 & & & 0,00 & & & 0,00 & & & 0,00 & & & 0,00 & & & 0,00 & & \\
\hline $21 / 03 / 2013$ & & 1 & 0,00 & & & 0,00 & & & 0,00 & & & 0,00 & & & 0,00 & & & 0,00 & & \\
\hline $21 / 03 / 2013$ & 21,8 & 2 & 0,00 & 0,00 & 0,00 & 0,00 & 0,00 & 0,00 & 0,00 & 0,00 & 0,00 & 0,00 & 0,00 & 0,00 & 0,00 & 0,00 & 0,00 & 0,00 & 0,00 & 0,00 \\
\hline $21 / 03 / 2013$ & & 3 & 0,00 & & & 0,00 & & & 0,00 & & & 0,00 & & & 0,00 & & & 0,00 & & \\
\hline $03 / 04 / 2013$ & & 1 & 0,00 & & & 0,00 & & & 0,00 & & & 0,00 & & & 0,00 & & & 0,00 & & \\
\hline $03 / 04 / 2013$ & 21 & 2 & 0,00 & 0,00 & 0,00 & 0,00 & 0,00 & 0,00 & 0,00 & 0,00 & 0,00 & 0,01 & 0,00 & 0,00 & 0,00 & 0,00 & 0,00 & 0,01 & 0,01 & 0,00 \\
\hline 03/04/2013 & & 3 & 0,00 & & & 0,00 & & & 0,00 & & & 0,00 & & & 0,00 & & & 0,00 & & \\
\hline $13 / 04 / 2013$ & & 1 & 0,00 & & & 0,00 & & & 0,00 & & & 0,00 & & & 0,00 & & & 0,01 & & \\
\hline $13 / 04 / 2013$ & 43 & 2 & 0,00 & 0,00 & 0,00 & 0,00 & 0,00 & 0,00 & 0,00 & 0,00 & 0,00 & 0,00 & 0,00 & 0,00 & 0,00 & 0,00 & 0,00 & 0,00 & 0,00 & 0,00 \\
\hline $13 / 04 / 2013$ & & 3 & 0,00 & & & 0,00 & & & 0,00 & & & 0,00 & & & 0,00 & & & 0,00 & & \\
\hline
\end{tabular}

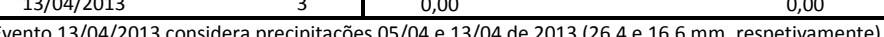


Determinação da Densidade do Solo sob Pastagem e Canade-Açúcar: Resultados 
Amostra Bequer Bequert Amostra Bequer+ Amostra Conteúdo Densidade Densidade Desvio amostra úmida úmida amostra seca seca gravimetrico amostra amostra padrão

\begin{tabular}{|c|c|c|c|c|c|c|c|c|c|}
\hline & (g) & (g) & (g) & (g) & (g) & (g) & & (media) & \\
\hline Pasto 301 & 68,35 & 191,99 & 123,64 & 182,05 & 113,7 & 0,087 & 1,689 & 1,66 & 0,03 \\
\hline Pasto 302 & 68,18 & 189,38 & 121,2 & 179,58 & 111,4 & 0,088 & 1,655 & & \\
\hline Pasto 303 & 68,28 & 188,5 & 120,22 & 178,6 & 110,32 & 0,090 & 1,639 & & \\
\hline Pasto 601 & 66,93 & 188,38 & 121,45 & 177,63 & 110,7 & 0,097 & 1,645 & 1,60 & 0,04 \\
\hline Pasto 602 & 68,68 & 184,7 & 116,02 & 175,43 & 106,75 & 0,087 & 1,586 & & \\
\hline Pasto 603 & 65,94 & 181,23 & 115,29 & 171,51 & 105,57 & 0,092 & 1,568 & & \\
\hline Pasto 901 & 66,71 & 179,22 & 112,51 & 169,88 & 103,17 & 0,091 & 1,533 & 1,52 & 0,01 \\
\hline Pasto 902 & 66,02 & 176,68 & 110,66 & 167,37 & 101,35 & 0,092 & 1,506 & & \\
\hline Pasto 903 & 68,03 & 179,64 & 111,61 & 170,41 & 102,38 & 0,090 & 1,521 & & \\
\hline Caña 301 & 67,6 & 183,21 & 115,61 & 173,7 & 106,1 & 0,090 & 1,576 & 1,56 & 0,02 \\
\hline Caña 302 & 66,57 & 180,24 & 113,67 & 170,69 & 104,12 & 0,092 & 1,547 & & \\
\hline Caña 303 & 66,46 & 179,48 & 113,02 & 170,39 & 103,93 & 0,087 & 1,544 & & \\
\hline Caña 601 & 67,52 & 176,88 & 109,36 & 168,73 & 101,21 & 0,081 & 1,504 & 1,53 & 0,03 \\
\hline Caña 602 & 68,44 & 178,54 & 110,1 & 170,18 & 101,74 & 0,082 & 1,511 & & \\
\hline Caña 603 & 68,04 & 182,2 & 114,16 & 173,53 & 105,49 & 0,082 & 1,567 & & \\
\hline Caña 901 & 64,82 & 176,43 & 111,61 & 167,55 & 102,73 & 0,086 & 1,526 & 1,52 & 0,00 \\
\hline Caña 902 & 68,6 & 179,94 & 111,34 & 170,98 & 102,38 & 0,088 & 1,521 & & \\
\hline Caña 903 & 66,63 & 177,88 & 111,25 & 168,98 & 102,35 & 0,087 & 1,520 & & \\
\hline
\end{tabular}

\section{Densidade do solo}

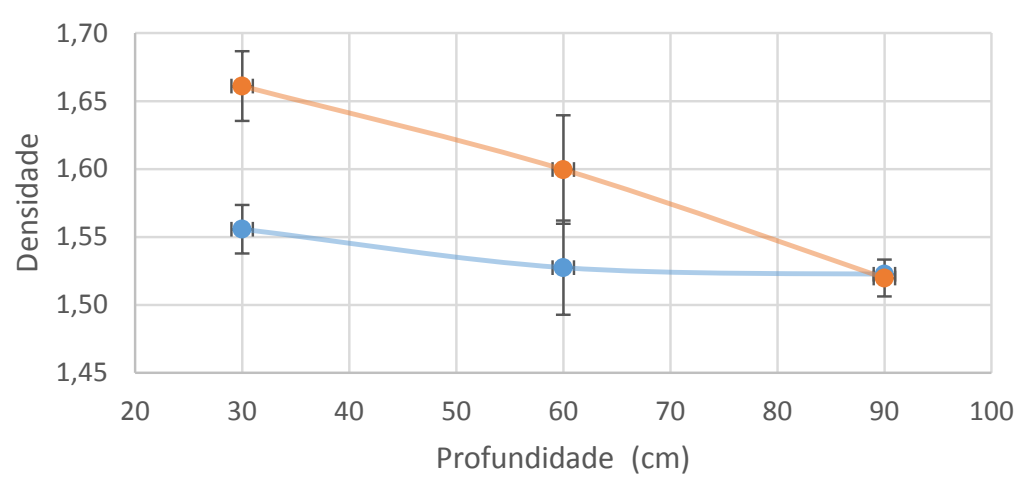

